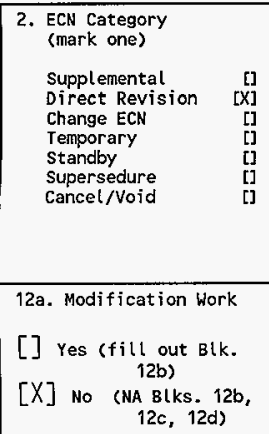

13a. Description of Change

3. Originator's Name, Organization, MSIN, and Telephone No.

John M. Conner, Data Assessment and Interpretation, R2-12, 3732711

6. Project Title/No./Work Order No. Tank 241-AP-101

9. Document Numbers Changed by this $E C N$ (includes sheet no. and rev.)

WHC-SD-WM-ER-357, Rev. 0

\begin{tabular}{|l|l|}
\hline $\begin{array}{l}\text { 4. USQ Required? } \\
{[] \text { Yes [X] No }}\end{array}$ & $\begin{array}{l}\text { 5. Date } \\
06 / 18 / 97\end{array}$ \\
\hline $\begin{array}{c}\text { 7. Bldg./Sys./Fac. No. } \\
241-A P-101\end{array}$ & $\begin{array}{c}\text { 8. Approval Designator } \\
\text { N/A }\end{array}$ \\
\hline $\begin{array}{l}\text { 10. Related ECN No(s). } \\
\text { N/A }\end{array}$ & $\begin{array}{c}\text { 11. Related PO No. } \\
\text { N/A }\end{array}$ \\
\hline
\end{tabular}

12b. Work Package $12 \mathrm{c}$. Modification Work Complete No.

$\mathrm{N} / \mathrm{A}$
$N / A$

Design Authority/Cog. Engineer Signature \& Date 12d. Restored to Original Condition (Temp. or Standby ECN only) $\mathrm{N} / \mathrm{A}$

This ECN was generated in order to revise the document to the new format per Department of Energy performance agreements.

14a. Justification (mark one)

$\begin{array}{llllllll}\text { Criteria Change } & {[]} & \text { Design Improvement } & {[]} & \text { Environmental } & {[]} & \text { Facility Deactivation } \\ \text { As-Found } & {[X]} & \text { Facilitate Const } & {[]} & \text { Const. Error/Omission } & {[]} & \text { Design Error/Omission } & \text { [] }\end{array}$

14b. Justification Details

This document was revised per Department of Energy performance agreements and direction from the Washington State Department of Ecology to revise 23 tank characterization reports (letter dated $7 / 6 / 95$ ).
15. Distribution (include name, MSIN, and no. of copies) See attached distribution.

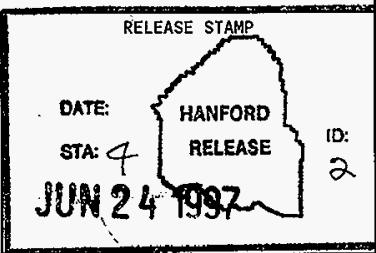




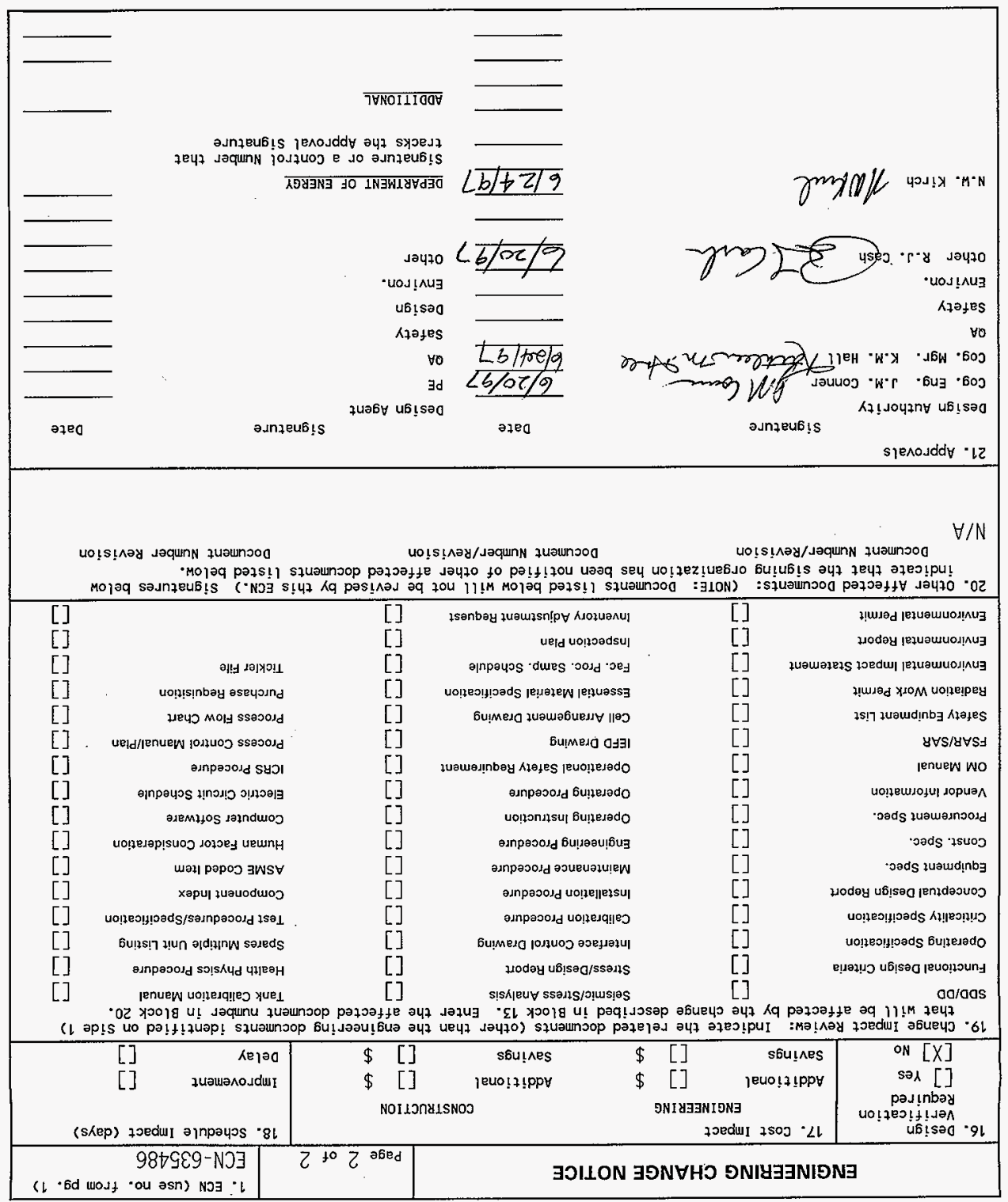




\section{Tank Characterization Report for Double-Shell Tank 241-AP-101}

John M. Conner

Lockheed Martin Hanford Corp. . Richland, WA 99352

U.S. Department of Energy Contract DE-AC06-87RL10930

EDT/ECN: $\quad$ ECN-635486

Org Code: 74620

UC: 2070

B\&R Code: EW 3120074 Total Pages: $/ 31$

Key Words: Waste Characterization, Double-She 11 Tank. DST, Tank 241-AP101. Tank AP-101, AP-101, AP Farm, Tank Characterization Report, TCR, Waste Inventory. TPA Milestone M-44

Abstract: This document summarizes the information on the historical uses, present status, and the sampling and analysis results of waste stored in Tank 241-AP-101. This report supports the requirements of the Tri-Party Agreement Milestone M-44-05.

TRADEMARK DISCLAIMER. Reference herein to any specific commercial product, process, or service by trade name, trademark, manufacturer, or otherwise, does not necessarily constitute or imply its endorsement, recommendation, or favoring by the United States Government or any agency thereof or its contractors or subcontractors.

Printed in the United States of America. To obtain copies of this document, contact: WHC/BCS Document Control Services, P.0. Box 1970, Mailstop H6-08, Richland WA 99352, Phone (509) 372-2420; Fax (509) 376-4989.
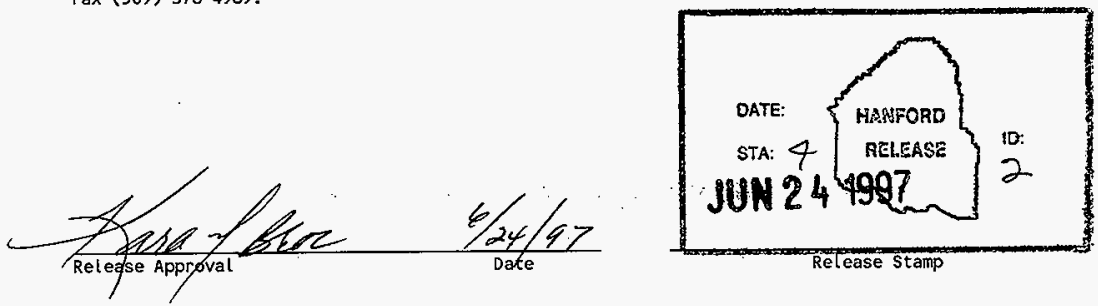

\section{Approved for Public Release}


(2) Title

Tank Characterization Report for Double-Shell Tank 241-AP-101

CHANGE CONTROL RECORD

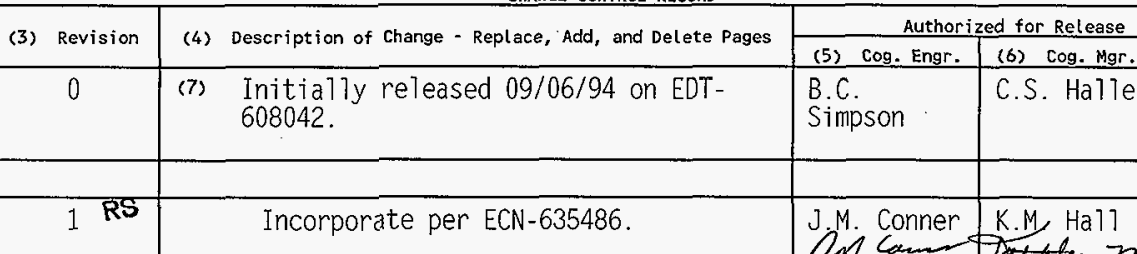




\title{
Tank Characterization Report for Double-Shell Tank 241-AP-101
}

\author{
J. M. Conner \\ L. W. Shelton, Jr. \\ Lockheed Martin Hanford Corporation \\ L. C. Amato \\ Los Alamos Technical Associates \\ T. L. Welsh \\ $B$ \& W Protec, inc. \\ J. L. Stroup \\ Fluor Daniel Northwest \\ Date Published \\ June 1997
}

Prepared for the U.S. Department of Energy

Assistant Secretary for Environmental Management

Project Hanford Management Contractor for the

U.S. Department of Energy under Contract DE-AC06-96RL13200

Approved for public release; distribution is unlimited 


\section{CONTENTS}

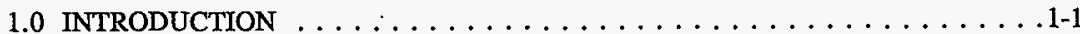

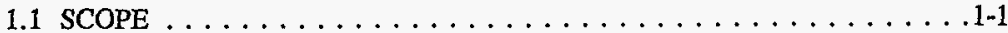

1.2 TANK BACKGROUND $\ldots \ldots \ldots \ldots \ldots \ldots \ldots \ldots \ldots \ldots \ldots$

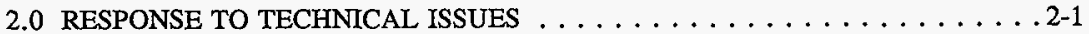

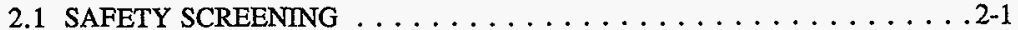

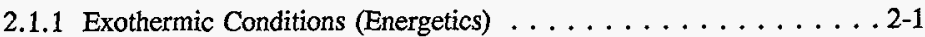

2.1 .2 Flammable Gas . . . . . . . . . . . . . . . 2-2

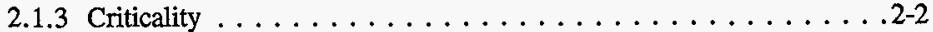

2.2 WASTE COMPATIBILITY EVALUATION $\ldots \ldots \ldots \ldots \ldots \ldots \ldots 2-2$

2.2.1 Safety Considerations . . . . . . . . . . . . . . 2-3

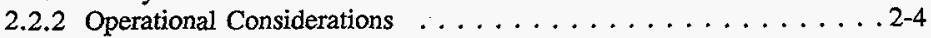

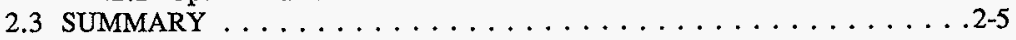

3.0 BEST-BASIS STANDARD INVENTORY ESTIMATE $\ldots \ldots \ldots \ldots \ldots \ldots$ 3-1

4.0 RECOMMENDATIONS $\ldots \ldots \ldots \ldots \ldots \ldots \ldots \ldots \ldots \ldots \ldots \ldots \ldots \ldots \ldots$

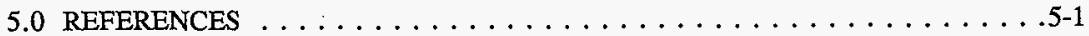

APPENDIXES

APPENDIX A: FISTORICAL TANK INFORMATION $\ldots \ldots \ldots \ldots \ldots \ldots$ A-1

A1.0 CURRENT TANK STATUS $\ldots \ldots \ldots \ldots \ldots \ldots \ldots \ldots \ldots \ldots$ A-3

A2.0 TANK DESIGN AND BACKGROUND $\ldots \ldots \ldots \ldots \ldots \ldots \ldots \ldots$ A-4

A3.0 PROCESS KNOWLEDGE $\ldots \ldots \ldots \ldots \ldots \ldots \ldots \ldots \ldots \ldots \ldots$ A $-9 . \ldots$

A3.1 WASTE TRANSFER HISTORY . . . . . . . . . . . A A-9

A3.2 HISTORICAL ESTIMATION OF TANK CONTENTS $\ldots \ldots \ldots \ldots$ A-11

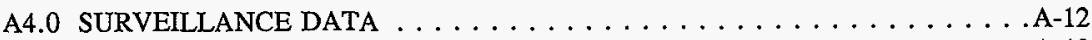

A4.1 SURFACE LEVEL READINGS $\ldots \ldots \ldots \ldots \ldots \ldots \ldots \ldots \ldots$ A-12

A4.2 INTERNAL TANK TEMPERATURES $\ldots \ldots \ldots \ldots \ldots \ldots \ldots \ldots$ A-12

A4.3 TANK 241 -AP-101 PHOTOGRAPHS $\ldots \ldots \ldots \ldots \ldots \ldots \ldots \ldots$ A-12

A5.0 APPENDIX A REFERENCES $\ldots \ldots \ldots \ldots \ldots \ldots \ldots \ldots \ldots \ldots \ldots$ A-15 


\section{TABLE OF CONTENTS (Continued)}

APPENDIX B: SAMPLING OF TANK $241-A P-101 \ldots \ldots \ldots \ldots$ B-1

B1.0 TANK SAMPLING OVERVIEW $\ldots \ldots \ldots \ldots \ldots \ldots \ldots \ldots \ldots$ B-3

B1.1 TANK 241-AP-101 1995 GRAB SAMPLING . . . . . . . . . . . B-4

B1.1.1 Description of Sampling Event $\ldots \ldots \ldots \ldots \ldots \ldots \ldots$ B-4

B1.1.2 Sample Handling $\ldots \ldots \ldots \ldots \ldots \ldots \ldots \ldots \ldots$

B1.1.3 Sample Analysis . . . . . . . . . . . . . . . B-5

B1.2 EVAPORATOR SLURRY SAMPLING . . . . . . . . . B-7

B1.2.1 242-A Evaporator. Campaign 95-1 Sampling . . . . . . . B-7

B1.2.2 Tank 241-AW-106 August 1995 Grab Sampling . . . . . . . . B-7

B1.3 DESCRIPTION OF HISTORICAL SAMPLING EVENTS . . . . . . . . B-8

B1.3.1 March 1995 Grab Sampling . . . . . . . . . . . . . . . B-8

B1.3.2 December 1994 Grab Sampling . . . . . . . . . . . . . . B-9

B1.3.3 July 1993 Grab Sampling . . . . . . . . . . . . . . . B-9

B2.0 ANALYTICAL RESULTS . . . . . . . . . . . . . . . . . B-10

B2.1 RESULTS FROM 1995 GRAB SAMPLING OF TANK 241-AP-101 . . B B-11

B2.1.1 Inorganic Analyses . . . . . . . . . . . . B-11

B2.1.2 Total Inorganic Carbon and Total Organic Carbon . . . . . B-15

B2.1.3 Radionuclides . . . . . . . . . . . . . . B-16

B2.1.4 Physical Properties Analyses $\ldots \ldots \ldots \ldots \ldots \ldots \ldots \ldots$ B-18

B2.1.5 Vapor Phase Measurement . . . . . . . . . . . . B-23

B2.2 TANK 241-AW-106 ANALYTICAL RESULTS . . . . . . . . . B-23

B2.3 HISTORICAL SAMPLE RESULTS . . . . . . . . . . . . . B-26

B2.3.1 Results from March 1995 Grab Sampling . . . . . . . . . . . B-27

B2.3.2 Results from December 1994 Grab Sampling . . . . . . . . B-27

B2.3.3 Results from July 1993 Grab Sampling . . . . . . . . . . B-28

B3.0 ASSESSMENT OF CHARACTERIZATION RESULTS $\ldots \ldots \ldots \ldots \ldots \ldots$ B-31

B3.1 FIELD OBSERVATIONS . . . . . . . . . . . . . . B-31

B3.2 QUALITY CONTROL ASSESSMENT $\ldots \ldots \ldots \ldots \ldots \ldots \ldots \ldots$ B-31

B3.3 DATA CONSISTENCY CHECKS . . . . . . . . . . . . . B-32

B3.3.1 Comparison of Results from Different Analytical Methods . . . B-32

B3.3.2 Mass and Charge Balances ... . . . . . . . . . B-34

B3.4 MEAN CONCENTRATIONS AND CONFIDENCE INTERVALS . . . B-37

B3.4.1 Mean Concentrations . . . . . . . . . . . . B-38

B3.4.2 Analysis of Variance Model . . . . . . . . . . . B-43

B3.4.3 Sampling Based Tank Inventory $\ldots \ldots \ldots \ldots \ldots \ldots$ B-44

B4.0 APPENDIX B REFERENCES $\ldots \ldots \ldots \ldots \ldots \ldots \ldots \ldots \ldots$ B-47 


\section{TABLE OF CONTENTS (Continued)}

APPENDIX C: STATISTICS FOR SAFETY SCREENING DATA QUALITY OBJECTIVE $\ldots \ldots \ldots \ldots \ldots \ldots \ldots \ldots \ldots \ldots \ldots \ldots \ldots \ldots$

C1.0 STATISTICAL ANALYSIS: CONFIDENCE LEVELS $\ldots \ldots \ldots \ldots \ldots$ C-3

C2.0 APPENDIX C REFERENCES . . . . . . . . . . . . C-6

APPENDIX D: RESULTS OF THE EVALUATION TO ESTABLISH BEST-BASIS

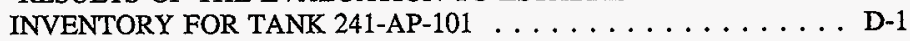

D1.0 CHEMICAL INFORMATION SOURCES $\ldots \ldots \ldots \ldots \ldots$ D-3

D2.0 COMPARISON OF COMPONENT INVENTORY VALUES $\ldots \ldots \ldots \ldots$ D-4

D3.0 COMPONENT INVENTORY EVALUATION $\ldots \ldots \ldots \ldots \ldots \ldots \ldots$ D-4 D3.1 CONTRIBUTING WASTE TYPES $\ldots \ldots \ldots \ldots \ldots \ldots \ldots$ D-4 D3.2 EVALUATION OF HISTORICAL DATA $\ldots \ldots \ldots \ldots \ldots$ D-5

D4.0 DEFINE THE BEST BASIS AND ESTABLISH COMPONENT

INVENTORIES $\ldots \ldots \ldots \ldots \ldots \ldots \ldots \ldots \ldots$ D-14

D5.0 APPENDIX D REFERENCES $\ldots \ldots \ldots \ldots \ldots \ldots \ldots \ldots \ldots \ldots \ldots$

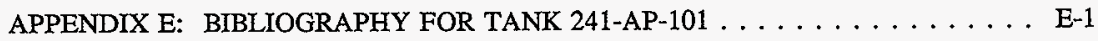




\section{LIST OF FIGURES}

A2-1 Riser Configuration for Tank $241-A P-101 \ldots \ldots \ldots \ldots$. . . . . . . . A-7

A2-2 Tank 241-AP-101 Cross Section and Schematic . . . . . . . . . . A-8

A4-1 Tank 241-AP-101 Level History . . . . . . . . . . . . . . . . . . . . . A-13

A4-2 Tank 241-AP-101 High Temperature Plot . . . . . . . . . . . . . . A-14

\section{LIST OF TABLES}

1-1 Summary of Recent Sampling Events $\ldots \ldots \ldots \ldots \ldots \ldots \ldots$ 1-2

1-2 Description and Status of Tank 241-AP-101. . . . . . . . . . . 1-3

2-1 Tank 241-AP-101 Projected Head Load . . . . . . . . . . . . . . . . 2-4

2-2 Summary of Safety Screening and Waste Compatibility Evaluations . . . . . . 2-6

3-1 Best-Basis Inventory Estimates for Nonradioactive Components in Tank 241-AP-101 as of January 31, $1997 \ldots \ldots$. . . . . . . . . . 3-2

3-2 Best-Basis Inventory Estimates for Radioactive Components in

Tank 241-AP-101 as of January 31, 1997 (Decayed to January 1, 1994) . . . . . . 3-3

4-1 Acceptance of Tank 241-AP-101 Sampling and Analysis . . . . . . . . 4-1

4-2 Acceptance of Evaluation of Characterization Data and Information for Tank $241-\mathrm{AP}-101 \ldots \ldots \ldots \ldots \ldots \ldots \ldots \ldots \ldots \ldots \ldots .2$

A1-1 Estimated Tank Contents as of January $31,1997 \ldots \ldots \ldots \ldots \ldots$. . . . . . .

A2-1 Tank 241-AP-101 Risers . . . . . . . . . . . . . . A-5

A3-1 Tank 241-AP-101 Transfer History . . . . . . . . . . . . . . A-10

B1-1 Integrated Data Quality Objective Requirements for Tank 241-AP-101 . . . . B-4

B1-2 Grab Sample Descriptions . . . . . . . . . . . . . B B-5 


\section{LIST OF TABLES (Continued)}

B1-3 Sample Analysis Summary $\ldots \ldots \ldots \ldots \ldots \ldots \ldots \ldots \ldots$ B-6

B1-4 Tank 241-AW-106 Sample Analysis Summary . . . . . . . . . . . . B-8 B2-1 Analytical Presentation Tables $\ldots \ldots \ldots \ldots \ldots \ldots \ldots \ldots \ldots$ B-10

B2-2 Tank 241-AP-101 Analytical Results: Aluminum . . . . . . . . . . B-11

B2-3 Tank 241-AP-101 Analytical Results: Iron $\ldots \ldots \ldots \ldots \ldots \ldots$ B-12

B2-4 Tank 241-AP-101 Analytical Results: Sodium . . . . . . . . . . . B-12

B2-5 Tank 241-AP-101 Analytical Results: Chloride . . . . . . . . . . . B-13

B2-6 Tank 241-AP-101 Analytical Results: Fluoride . . . . . . . . . . . B-13

B2-7 Tank 241-AP-101 Analytical Results: Hydroxide . . . . . . . . . . . B-13

B2-8 Tank 241-AP-101 Analytical Results: Nitrate . . . . . . . . . . . . B-14

B2-9 Tank 241-AP-101 Analytical Results: Nitrite . . . . . . . . . . . . . . B-14

B2-10 Tank 241-AP-101 Analytical Results: Phosphate . . . . . . . . . . . B-14

B2-11 Tank 241-AP-101 Analytical Results: Sulfate . . . . . . . . . . . . B-15

B2-12 Tank 241-AP-101 Analytical Results: Total Inorganic Carbon . . . . . . . . B B-15

B2-13 Tank 241-AP-101 Analytical Results: Total Organic Carbon . . . . . . . . . . B-16

B2-14 Tank 241-AP-101 Analytical Results: Total Alpha Activity . . . . . . . . . . B-16

B2-15 Tank 241-AP-101 Analytical Results: Americium-241 . . . . . . . . . . B-17

B2-16 Tank 241-AP-101 Analytical Results: Cesium-137 . . . . . . . . . . B-17

B2-17 Tank 241-AP-101 Analytical Results: Cobalt-60 . . . . . . . . . . B-17

B2-18 Tank 241-AP-101 Analytical Results: Plutonium-239/240 . . . . . . . . . . B-18 


\section{LIST OF TABLES (Continued)}

B2-19 Tank 241-AP-101 Analytical Results: Strontium-89/90 . . . . . . . . . B-18

B2-20 Tank 241-AP-101 Analytical Results: Weight Percent Water by

Thermogravimetric Analysis . . . . . . . . . . . . . . B 19

B2-21 Tank 241-AP-101 Analytical Results:

Differential Scanning Calorimetry $\ldots \ldots \ldots \ldots \ldots \ldots \ldots \ldots$. . . . . . . .

B2-22 Tank 241-AP-101 Analytical Results: Specific Gravity . . . . . . . . . B-22

B2-23 Tank 241-AP-101 Analytical Results: $\mathrm{pH} \ldots \ldots \ldots \ldots \ldots \ldots \ldots \ldots$. . . . . 22

B2-24 Vapor Phase Measurement Results for Tank 241-AP-101 . . . . . . . . . B-23

B2-25 Evaporator Campaign 95-1 Slurry and Tank 241-AW-106

Analytical Results . . . . . . . . . . . . . . . B-24

B2-26 Tank 241-AW-106 Analytical Results: Weight Percent Water . . . . . . . . B-26

B2-27 Tank 241-AW-106 Analytical Results:

Differential Scanning Calorimetry . . . . . . . . . . . . . B B-26

B2-28 Results from March 1995 Grab Sampling . . . . . . . . . . . . . B-27

B2-29 Results from December 1994 Grab Sampling . . . . . . . . . . . . . . . . B-28

B2-30 1993 Historical Data Summary for Tank 241-AP-101 . . . . . . . . . . . . . B B-29

B3-1 Comparison of Total Alpha Activity with the Sum of the Activities

of the Individual Alpha Emitters. . . . . . . . . . . . . B-33

B3-2 Comparison of Total Beta Activity with the Sum of the Activities

of the Individual Beta Emitters $\ldots \ldots \ldots \ldots \ldots$ B-33

B3-3 Cation Mass and Charge Data. . . . . . . . . . . . . . B-35

B3-4 Anion Mass and Charge Data $\ldots \ldots \ldots \ldots \ldots \ldots \ldots$ B-35

B3-5 Mass Balance Totals . . . . . . . . . . . . . . . B-36 


\section{LIST OF TABLES (Continued)}

B3-6 Tank 241-AP-101 Summary Statistics Mean Concentrations (Nested Analysis of Variance) . . . . . . . . . . . . . . B-39

B3-7 Tank 241-AP-101 Summary Statistics Mean Concentrations (One-Way Analysis of Variance) $\ldots \ldots \ldots \ldots \ldots \ldots \ldots \ldots$. . . . . . . . .

B3-8 Tank 241-AP-101 Analytes with $>50$ Percent "Less-Than" Values . . . . . . B-40 B3-9 Tank 241-AW-106 Summary Statistics - Mean Concentrations . . . . . . . . B-41

B3-10 Tank 241-AW-106 Analytes with $\geq 50$ Percent "Less-Than" Values . . . . . . B-42

B3-11 Analytical-Based Inventory for Tank $241-A P-101 \ldots \ldots \ldots \ldots$. . . . . . . . .

C1-1 Summary Statistics - Differential Scanning Calorimetry . . . . . . . . C-4

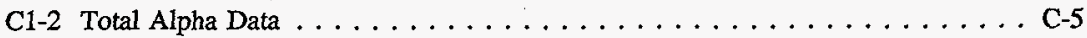

C1-3 Summary Statistics $-{ }^{239240} \mathrm{Pu} \ldots \ldots \ldots \ldots \ldots \ldots \ldots$ C-6

D3-1 Chronology of Transfers for Tank 241-AP-101 as of

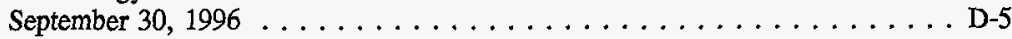

D3-2 Results of November 1995 Sampling of Tank 241-AP-101 . . . . . . . . D-6

D3-3 Composition of Tank 241-AP-101 as of November 1995: Homogeneity Versus Stratification $\ldots \ldots \ldots \ldots \ldots \ldots \ldots \ldots \ldots$

D3-4 Estimated and Analytical Compositions for Waste in Tank 241-AP-101 as of November $1995 \ldots \ldots \ldots \ldots$. . . . . . . . . . . . . . D-9

D3-5 Estimated and Analytical Inventories for Waste in Tank 241-AP-101

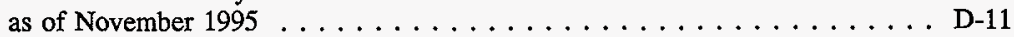

D3-6 Concentration Estimates for Waste Received from Tank 241-AW-106 in March 1996 and January 1997 . . . . . . . . . . . . . . . . D-13 


\section{LIST OF TABLES (Continued)}

D4-1 Best-Basis Inventory Estimates for Nonradioactive Components in Tank 241-AP-101 as of September 30, $1996 \ldots \ldots \ldots \ldots \ldots \ldots$ D-14

D4-2 Best-Basis Inventory Estimates for Radioactive Components in Tank 241-AP-101 as of September 30, 1996 (Decayed to January 1,1994$) \ldots \ldots \ldots \ldots \ldots \ldots \ldots$. . . . . . . . . . . . 


\section{LIST OF TERMS}

$\begin{array}{ll}\text { ANOVA } & \text { analysis of variance } \\ \text { Btu/hr } & \text { British thermal units per hour } \\ \text { Ci } & \text { curie } \\ \text { Ci/g } & \text { curies per gram } \\ \text { Ci/L } & \text { curies per liter } \\ \text { cm } & \text { centimeter } \\ \text { DQO } & \text { data quality objective } \\ \text { DSC } & \text { differential scanning calorimetry } \\ \text { DSSF } & \text { double-shell slurry feed } \\ \text { ft } & \text { feet } \\ \text { g/L } & \text { grams per liter } \\ \text { GEA } & \text { gamma energy analysis } \\ \text { HDW } & \text { Hanford Defined Waste } \\ \text { IC } & \text { ion chromatography } \\ \text { ICP } & \text { inductively coupled plasma spectroscopy } \\ \text { in. } & \text { inch } \\ \text { J/g } & \text { joules per gram } \\ \text { kg } & \text { kilogram } \\ \text { kgal } & \text { kilogallon } \\ \text { kL } & \text { kiloliter } \\ \text { LFL } & \text { lower flammability limit } \\ \text { LL } & \text { lower limit } \\ \text { m } & \text { meter } \\ M & \text { moles per liter } \\ \text { mL } & \text { milliliter } \\ \text { mm } & \text { millimeter } \\ \text { n/a } & \text { not applicable } \\ \text { n/r } & \text { not reported } \\ \text { nCi/g } & \text { nanocuries per gram } \\ \text { PASF } & \text { PUREX ammonia scrubber feed } \\ \text { PHMC } & \text { Project Hanford Management Contractor } \\ \text { ppmv } & \text { parts per million by volume } \\ \text { PUREX } & \text { Plutonium-Uranium Extraction process } \\ \text { QC } & \text { quality control } \\ \text { REML } & \text { restricted maximum likelihood estimation } \\ \text { RPD } & \text { relative percent difference } \\ \text { SAP } & \text { sampling and analysis plan } \\ \text { SMM } & \text { Supernatant Mixing Model } \\ \text { SpG } & \text { specific gravity } \\ & \\ & \end{array}$




\section{LIST OF TERMS (Continued)}

TCR

TGA

TIC

TLM

TOC

TRU

TWRS

UL

W

W/Ci

WSTRS

wt\%

$\%$

${ }^{\circ} \mathrm{C}$

${ }^{\circ} \mathrm{F}$

$\mu \mathrm{Ci} / \mathrm{g}$

$\mu \mathrm{Ci} / \mathrm{mL}$

$\mu \mathrm{eq} / \mathrm{g}$

$\mu \mathrm{g} / \mathrm{g}$

$\mu \mathrm{g} / \mathrm{mL}$

$\mu \mathrm{g} \mathrm{C} / \mathrm{g}$

$\mu \mathrm{g} \mathrm{C} / \mathrm{mL}$ tank characterization report

thermogravimetric analysis

total inorganic carbon

Tank Layer Model

total organic carbon

transuranic

Tank Waste Remediation System

upper limit

watt

watts per curie

Waste Status and Transaction Record Summary

weight percent

percent

degrees Celsius

degrees Fahrenheit

microcuries per gram

microcuries per milliliter

microequivalents per gram

micrograms per gram

micrograms per milliliter

micrograms of carbon per gram

micrograms of carbon per milliliter 


\subsection{INTRODUCTION}

One major function of the Tank Waste Remediation System (TWRS) is to characterize wastes in support of waste management and disposal activities at the Hanford Site. Analytical data from sampling and analysis and other available information about a tank are compiled and maintained in a tank characterization report (TCR). This report and its appendixes serve as the TCR for double-shell tank 241-AP-101. The objectives of this report are: 1) to use characterization data in response to technical issues associated with tank 241-AP-101 waste; and 2) to provide a standard characterization of this waste in terms of a best-basis inventory estimate. Section 2.0 summarizes the response to technical issues, Section 3.0 provides the best-basis inventory estimate, and Section 4.0 makes recommendations about safety status and additional sampling needs. The appendixes contain supporting data and information. This report supported the requirements of the Hanford Federal Facility Agreement and Consent Order (Ecology et al. 1996), Milestone M-44-05.

\subsection{SCOPE}

The characterization information in this report originated from sample analyses and known historical sources. Appendix A provides historical information for tank 241-AP-101 including surveillance information, records pertaining to waste transfers and tank operations, and expected tank contents derived from a model based upon process knowledge.

Appendix B summarizes recent sampling events (see also Table 1-1) and historical sampling information. Tank 241-AP-101 was grab sampled in November 1995, when the tank contained $2,790 \mathrm{~kL}(737 \mathrm{kgal})$ of waste. An additional $1,438 \mathrm{~kL}$ (380 kgal) of waste was received from tank 241-AW-106 in transfers on March 1996 and January 1997. This waste was the product of the 242-A Evaporator Campaign 95-1. Characterization information for the additional 1,438 $\mathrm{kL}$ ( $380 \mathrm{kgal})$ was obtained using grab sampling data from tank 241-AW-106 and a slurry sample from the evaporator. Appendix $C$ reports on the statistical analysis and numerical manipulation of data used in issue resolution. Appendix D contains the evaluation to establish the best basis for the inventory estimate and the statistical analysis performed for this evaluation. Appendix $\mathrm{E}$ is a bibliography that resulted from an in-depth literature search of all known information sources applicable to tank 241-AP-101 and its respective waste types. A majority of the reports listed in Appendix E are available in the Tank Characterization and Safety Resource Center. 
Table 1-1. Summary of Recent Sampling Events.

\begin{tabular}{|c|c|c|c|}
\hline Shmilerosto & ipinso & 10001100 & 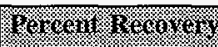 \\
\hline $\begin{array}{l}\text { Headspace gas flammability } \\
\text { (November 1995) }\end{array}$ & Gas & $\begin{array}{l}\text { Tank headspace, } 6 \mathrm{~m} \\
(20 \mathrm{ft}) \text { below top of risers } \\
1 \text { at } 210^{\circ} \text { and } 1 \text { at } 330^{\circ}\end{array}$ & $n / a$ \\
\hline Grab (November 1995) & Liquid & $\begin{array}{l}\text { Risers } 1 \text { at } 210^{\circ} \text { and } 1 \text { at } \\
330^{\circ}\end{array}$ & $100 \%$ \\
\hline $\begin{array}{l}\text { 242-A Evaporator slurry product } \\
\text { from Campaign } 95-1 \text { (July 1995). } \\
\text { Waste was transferred into } \\
\text { tank 241-AP-101 via } \\
\text { tank 241-AW-106. }\end{array}$ & Liquid & $\mathrm{n} / \mathrm{a}$ & $\begin{array}{l}\text { Unknown, } \\
\text { although likely } \\
100 \%\end{array}$ \\
\hline $\begin{array}{l}\text { The August } 1995 \text { grab sample of } \\
\text { the tank } 241 \text {-AW-106 supernatant } \\
\text { was transferred into } \\
\text { tank 241-AP-101 in March } 1996 \\
\text { and January } 1997 .\end{array}$ & Liquid & $\begin{array}{l}\text { Riser } 16 \mathrm{~B} \text { of } \\
\operatorname{tank} 241-\mathrm{AW}-106\end{array}$ & $100 \%$ \\
\hline
\end{tabular}

Note:

$$
\mathrm{n} / \mathrm{a}=\text { not applicable }
$$

\subsection{TANK BACKGROUND}

Tank 241-AP-101 is located in the 200 East Area AP Tank Farm on the Hanford Site. The tank went into service in 1986 and received a small amount of unknown waste (probably water). The tank was almost completely filled with PUREX ammonia scrubber feed (a dilute noncomplexed waste) in 1988. Later in 1988, a majority of this waste was removed for processing through the 242-A Evaporator. The tank has participated in several other evaporator campaigns throughout its service life. Each time, the tank was almost completely filled before the campaign, then emptied by the end of the campaign. The last such campaign occurred in January 1995 when the tank was reduced to $295 \mathrm{~kL}$ (78 kgal). Since then, the tank has received $2,498 \mathrm{~kL}(660 \mathrm{kgal})$ of double-shell slurry feed (DSSF) from tank 241-AP-105 in August 1995 and $1,438 \mathrm{~kL}$ (380 kgal) of dilute noncomplexed waste from tank 241-AW-106 in March 1996 and January 1997.

Table 1-2 summarizes a description of tank 241-AP-101. The tank has an operating capacity of $4,390 \mathrm{~kL}(1,160 \mathrm{kgal})$ and contains an estimated 4,224 kL (1,116 kgal) of waste based on a waste level of $1,031 \mathrm{~cm}$ (405.8 in.) (LMHC 1997). The waste is classified as DSSF slurry feed (Hanlon 1997). The tank is not on the Watch List (Public Law 101-510). 
HNF-SD-WM-ER-357 Rev. 1

Table 1-2. Description and Status of Tank 241-AP-101.

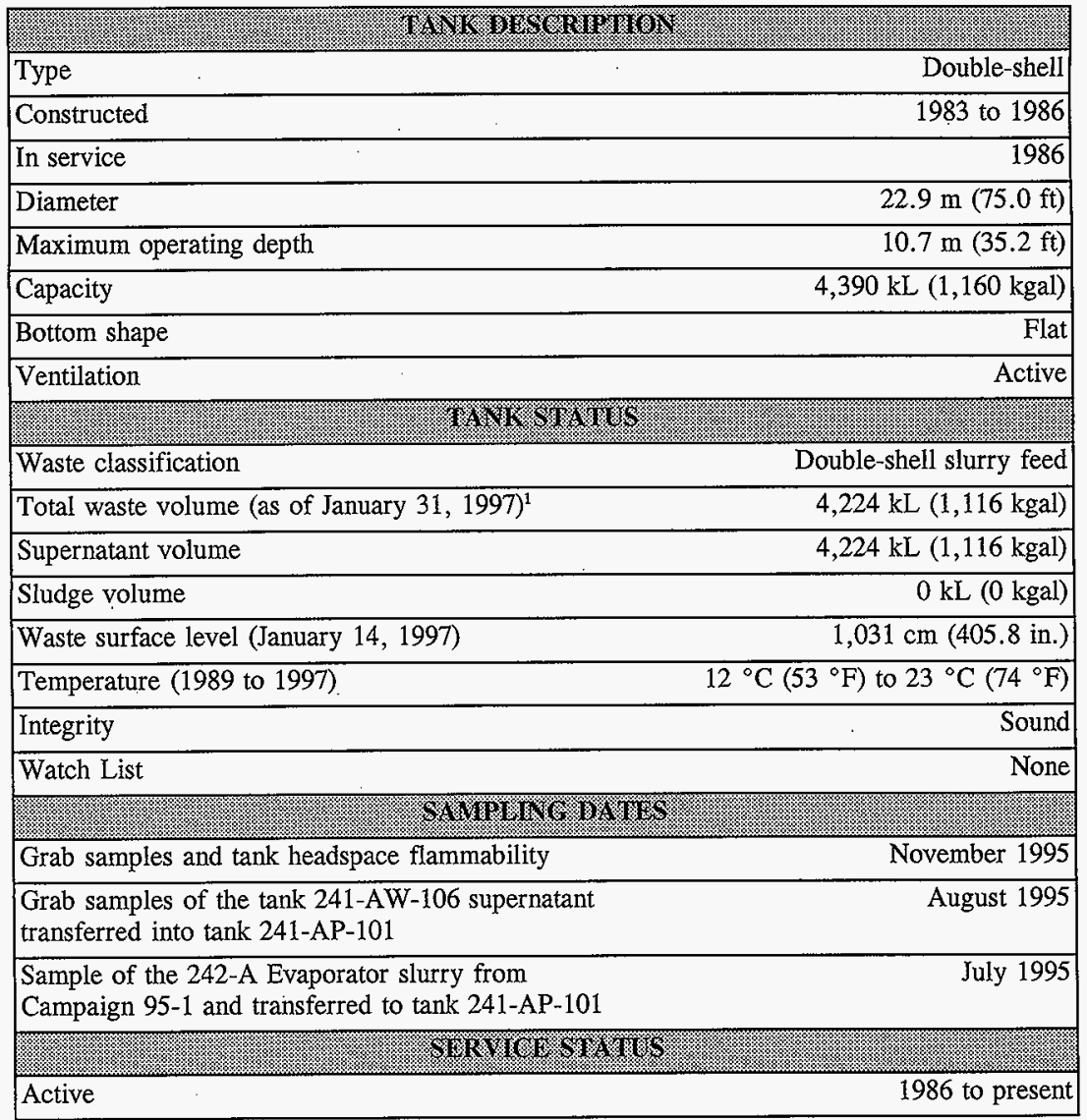

Note:

'Tank 241-AP-101 is active; any transfers will change the tank's volume and contents. 
HNF-SD-WM-ER-357 Rev. 1

This page intentionally left blank. 


\subsection{RESPONSE TO TECHNICAL ISSUES}

The following two technical issues have been identified for tank 241-AP-101.

- Does the waste pose or contribute to any recognized potential safety problems?

- Will the waste pose any safety or operational problems if combined with other wastes in the double-shell tank system?

The tank has not been sampled since the March 1996 and January 1997 waste transfers; therefore, data from different sources must be used to address these two issues. Data from the six grab samples taken in November 1995 can account for the properties of the 2,790 kL ( $737 \mathrm{kgal}$ ) of waste in the tank at that time, and data from samples taken at the 242-A Evaporator and in tank can account for the properties of the $1,438 \mathrm{~kL}(380 \mathrm{kgal})$ transferred to tank 241-AP-101 in 1996 and 1997. Results from a tank headspace flammability screening are used to address the vapor flammability issue. The response to technical issues is detailed in the following sections. Appendix B contains the sampling and analysis data for tank 241-AP-101 and other relevant samples.

\subsection{SAFETY SCREENING}

The data needed to screen the waste in tank 241-AP-101 for potential safety problems are documented in Tank Safety Screening Data Quality Objective (Dukelow et al. 1995). These potential safety problems are exothermic conditions in the waste, flammable gases in the waste and/or tank headspace, and criticality conditions in the waste. Each condition is addressed separately.

\subsubsection{Exothermic Conditions (Energetics)}

The first requirement outlined in the safety screening data quality objective (DQO) (Dukelow et al. 1995) is to ensure there is not sufficient fuel (organic or ferrocyanide) in tank 241-AP-101 waste to cause a safety hazard. Because of this requirement, energetics in the tank 241-AP-101 waste were evaluated. The threshold for energetics is an exotherm of $480 \mathrm{~J} / \mathrm{g}$ on a dry weight basis. Results obtained using differential scanning calorimetry (DSC) indicated that two of six grab samples exhibited exothermic reactions (Esch 1996). The dry weight exotherm for grab sample 1AP-95-4 was $97.5 \mathrm{~J} / \mathrm{g}$. The 95 percent confidence interval upper limit for this sample was $356.4 \mathrm{~J} / \mathrm{g}$, below the safety screening limit. The initial DSC run on grab sample 1AP-95-6 did not display an exothermic reaction. The duplicate, however, exhibited an exothermic reaction with a magnitude (dry weight) of $877 \mathrm{~J} / \mathrm{g}$. The 95 percent confidence interval upper limit for this sample was $1,146 \mathrm{~J} / \mathrm{g}$. A triplicate analysis did not show any exothermic reactions. The analysis was rerun in duplicate, and the exothermic reaction could not be reproduced. Consequently, it was 
concluded that some anomalous material, originating from the sample (for example, a particle of suspended solids) or a foreign material (for example, a piece of plastic "milling" from the pipet tip), interfered with the analysis of the bulk sample resulting in the observed exotherm (Bushaw 1996). Therefore, no secondary analyses were required to address the energetics issue. No exotherms were found in the tank 241-AW-106 sample or the evaporator slurry sample (Esch 1995 and Guthrie 1996).

No other analytical result indicated that exothermic reactions would be expected. No organic layer was observed. The total organic carbon (TOC) mean concentration was only $6,410 \mu \mathrm{g} \mathrm{C} / \mathrm{mL}(4,890 \mu \mathrm{g} \mathrm{C} / \mathrm{g})$ on a dry weight basis in tank $241-\mathrm{AP}-101$ samples and $13,900 \mu \mathrm{g} \mathrm{C} / \mathrm{mL}(10,600 \mu \mathrm{g} \mathrm{C} / \mathrm{g})$ in tank 241-AW-106 and evaporator slurry samples, well below the TOC action limit of $30,000 \mu \mathrm{g} / \mathrm{g}$.

\subsubsection{Flammable Gas}

Combustible gas meter measurements were taken in the tank headspace before the grab sampling in November 1995. The readings indicated that no flammable gas was detected ( 0 percent of the lower flammability limit [LFL]). The action limit is 25 percent of the LFL (Dukelow et al. 1995). Appendix B shows the results from this vapor phase measurement. It is important to note that waste has been transferred into the tank since this measurement was made.

\subsubsection{Criticality}

The safety screening DQO threshold for criticality, based on the total alpha activity, is $1 \mathrm{~g} / \mathrm{L}$. Because total alpha activity is measured in $\mu \mathrm{Ci} / \mathrm{mL}$ instead of $\mathrm{g} / \mathrm{L}$, the $1 \mathrm{~g} / \mathrm{L}$ limit is converted into units of $\mu \mathrm{Ci} / \mathrm{mL}$ by assuming that all alpha decay originates from ${ }^{239} \mathrm{Pu}$. Using the specific activity of ${ }^{239} \mathrm{Pu}(0.0615 \mathrm{Ci} / \mathrm{g})$, the $1 \mathrm{~g} / \mathrm{L}$ limit is converted to $61.5 \mu \mathrm{Ci} / \mathrm{mL}$. No grab sample from tank $241-\mathrm{AP}-101$ contained detectable quantities of alpha activity. The largest nondetected value was $<0.00341 \mu \mathrm{Ci} / \mathrm{mL}$. The tank 241-AW-106 supernatant sample and the evaporator slurry sample were also tested for total alpha activity, but the results for each sample were below detection limits. Confidence intervals could not be calculated because of the nondetected results. The results indicate no criticality concern exists for this waste.

\subsection{WASTE COMPATIBILITY EVALUATION}

The purpose of the waste compatibility evaluation is to assess the safety and operational implications of combining wastes in tank 241-AP-101 with other wastes in the double-shell tank system. Safety considerations include criticality, flammable gas accumulation, energetics, tank corrosion, and chemical compatibility. Operational considerations include transuranic (TRU) and complexant waste segregation, heat generation rates, waste 
pumpability, mixing of different waste types, and mixing of high phosphate waste. Some safety and operational considerations are outside the scope of this report, namely the chemical reactivity of the waste, waste pumpability, and mixing of different waste types. Data requirements for this evaluation are documented in Data Quality Objectives for Tank Farms Waste Compatibility Program (Fowler 1995).

\subsubsection{Safety Considerations}

The decision criteria threshold for criticality in source wastes is $0.013 \mathrm{~g} / \mathrm{L}$ plutonium. Using the specific activity of ${ }^{239} \mathrm{Pu}$, this limit was converted to $0.800 \mu \mathrm{Ci} / \mathrm{mL}$. The tank 241-AP-101 and 241-AW-106 mean results for ${ }^{239 / 240} \mathrm{Pu}$ were $1.64 \mathrm{E}-04$ and $2.18 \mathrm{E}-04 \mu \mathrm{Ci} / \mathrm{mL}$, respectively, well below the threshold.

To prevent the accumulation of flammable gas, a specific gravity decision criteria threshold of 1.3 has been established for source wastes. The tank 241-AP-101 and 241-AW-106 mean specific gravities were 1.31 and 1.26 , respectively. Therefore, the specific gravity mean from the six grab samples from tank 241-AP-101 slightly exceeded the limit. Combining the two specific gravity means (and weighting according to the volume of each portion) yielded an overall waste mean of 1.30 . Waste with specific gravities greater than 1.3 are still eligible for mixing with other tank wastes if the specific gravity of the commingled waste will be less than or equal to 1.41 .

Waste compatibility energetics concerns are evaluated using two decision rules. The first has to do with the exotherm/endotherm ratio for the waste; the waste must have a ratio less than 1 (that is, the net enthalpy change for the sample must be endothermic). Four of six grab samples did not exhibit any exothermic reactions. The two grab samples that did exhibit exothermic reactions had exotherm to endotherm ratios of 0.045 and 0.27 , well below the limit. The highest ratio (0.27) was calculated for sample 1AP-95-6. As reported in Section 2.1.1, the exotherm for this sample was attributed to anomalous material; therefore, the actual exotherm/endotherm ratio for the sample is expected to be much lower than 0.27 . The tank 241-AW-106 supernatant sample and the evaporator slurry sample exhibited no exotherms. The second decision rule directs an investigation of the samples for a separable organic layer. No organic layer was observed in any sample from either tank.

The corrosion decision rule specifies decision criteria thresholds for hydroxide, nitrite, and nitrate to prevent corrosion of the carbon steel tank components. The applicable corrosion decision rule in Fowler (1995) states that if the following conditions are met, a transfer of this waste may be allowed:

$$
\begin{gathered}
1.0 M<\left[\mathrm{NO}_{3}^{-}\right] \leq 3.0 \mathrm{M} ; \text { and } 0.1 \times\left[\mathrm{NO}_{3}^{-}\right] \leq\left[\mathrm{OH}^{-}\right]<10.0 \mathrm{M} ; \text { and } \\
{\left[\mathrm{OH}^{-}\right]+\left[\mathrm{NO}_{2}^{-}\right] \geq 0.4 \times\left[\mathrm{NO}_{3}^{-}\right]}
\end{gathered}
$$


The molarities of $2.48,0.907$, and 2.91 for nitrate, nitrite, and hydroxide (based on the tank 241-AP-101 samples), respectively, satisfied the specifications of this decision rule. Likewise, the tank 241-AW-106 and evaporator slurry samples also satisfied these criteria, with molarities of $1.52,0.846$, and 1.74 , for nitrate, nitrite, and hydroxide, respectively.

\subsubsection{Operational Considerations}

The TRU waste segregation decision criteria threshold is $100 \mathrm{nCi} / \mathrm{g}(0.1 \mu \mathrm{Ci} / \mathrm{g})$. Waste, which exceeds the criterion, must be stored in a TRU storage tank. For tank 241-AP-101, the mean analytical results for ${ }^{241} \mathrm{Am}$ and ${ }^{239 / 240} \mathrm{Pu}$ were summed, then divided by the mean specific gravity (1.31) to derive a TRU concentration of $3.73 \mathrm{E}-04 \mu \mathrm{Ci} / \mathrm{g}$. Similarly, for tank 241-AW-106 waste, a TRU concentration of $0.00104 \mu \mathrm{Ci} / \mathrm{g}$ was obtained using a mean specific gravity of 1.26 . Note the value used for ${ }^{241} \mathrm{Am}$ was the highest nondetect value. Based on these calculations, the waste is not TRU.

High phosphate waste should not be mixed with certain other waste types. Wastes with a phosphate concentration greater than $0.1 M(9,500 \mu \mathrm{g} / \mathrm{mL})$ are considered high phosphate waste. The mean phosphate results for tanks $241-\mathrm{AP}-101$ and $241-\mathrm{AW}-106$ were well below the limit with results of 908 and $1,560 \mu \mathrm{g} / \mathrm{mL}$, respectively.

A factor in assessing tank safety is the heat generation and temperature of the waste. Heat is generated in the tanks from radioactive decay. The waste compatibility DQO decision threshold for the heat generation rate of the waste is the same as the operating specification document limit. Table 2-1 show the radionuclide analytical data used to calculate the tank heat load. Only radionuclides with detected results in both data sets and with decay heats listed in Kirkpatrick and Brown (1984) were used in the calculation. The calculated heat load of $3,170 \mathrm{~W}(10,800 \mathrm{Btu} / \mathrm{hr})$ is well below the operating specification of $20,500 \mathrm{~W}$ (70,000 Btu/hr) for the AP Tank Farm (Harris 1996). No heat load estimates were available based on process history or tank headspace temperatures.

Table 2-1. Tank 241-AP-101 Projected Heat Load.

\begin{tabular}{|c|c|c|c|}
\hline 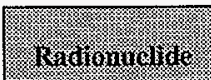 & 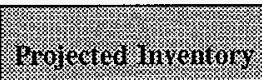 & 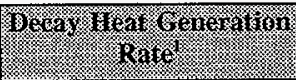 & 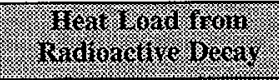 \\
\hline & 1: & 9. & (4) \\
\hline 装7 $\mathrm{Cs}$ & $6.72 \mathrm{E}+05$ & 0.00472 & 3,170 \\
\hline${ }^{239 / 240} \mathrm{Pu}$ & 0.709 & 0.0306 & 0.0217 \\
\hline${ }^{89 / 90} \mathrm{Sr}$ & 548 & 0.00669 & 3.67 \\
\hline Total & & & 3,170 \\
\hline
\end{tabular}

Note:

${ }^{1}$ Kirkpatrick and Brown (1984) 


\subsection{SUMMARY}

Because tank 241-AP-101 has not been sampled since the latest transfers of waste into the tank, characterization data from an earlier sampling event and analytical data for the waste transferred into the tank were both evaluated. Together, these results adequately describe the waste currently in the tank. The results from all analyses performed to address potential safety issues of the safety screening DQO (Dukelow et al. 1995) showed that no primary analyte exceeded the decision threshold limits. Although one sample did produce an exothermic reaction greater than the safety screening limit, this observation was not reproducible and was attributed to some anomalous material.

The flammability screening was performed before the last waste additions to the tank.

The waste compatibility evaluation revealed that, except for specific gravity, the results were within the desired ranges of the waste compatibility DQO (Fowler). Although the specific gravity of the tank 241-AP-101 grab samples slightly exceeded the 1.3 limit for source wastes, the mean analytical result of 1.31 was below the commingled waste threshold of 1.41. Table 2-2 summarizes the safety screening and waste compatibility evaluations. 
Table 2-2. Summary of Safety Screening and Waste Compatibility Evaluations. (2 sheets)

\begin{tabular}{|c|c|c|}
\hline 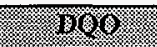 & 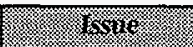 & Residil. \\
\hline \multirow[t]{4}{*}{$\begin{array}{l}\text { Safety } \\
\text { screening }\end{array}$} & Energetics & $\begin{array}{l}\text { Two samples exhibited exothermic reactions. One } \\
\text { exotherm exceeded the } 480 \mathrm{~J} / \mathrm{g} \text { limit, but it was not } \\
\text { reproducible and was attributed to an anomalous material. }\end{array}$ \\
\hline & Flammable gas & $\begin{array}{l}\text { Vapor measurement (by combustible gas meter) reported } \\
0 \text { percent of LFL. It was performed before waste was } \\
\text { added from tank } 241-\mathrm{AW}-106 \text {. }\end{array}$ \\
\hline & Criticality & $\begin{array}{l}\text { All total alpha activity results and } 95 \text { percent confidence } \\
\text { interval upper limits were well below } 61.5 \mu \mathrm{Ci} / \mathrm{mL} \\
\text { threshold. }\end{array}$ \\
\hline & $\begin{array}{l}\text { Separable } \\
\text { organic layer }\end{array}$ & $\begin{array}{l}\text { No separable organic layer was found in any grab } \\
\text { sample. }\end{array}$ \\
\hline \multirow{9}{*}{$\begin{array}{l}\text { Waste } \\
\text { compatibility }\end{array}$} & \multicolumn{2}{|c|}{ 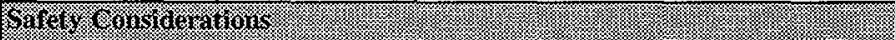 } \\
\hline & Criticality & $\begin{array}{l}\text { All results were below the limit of } 0.013 \mathrm{~g} / \mathrm{L}(0.800 \\
\mu \mathrm{Ci} / \mathrm{mL}) \text {. }\end{array}$ \\
\hline & Flammable gas & $\begin{array}{l}\text { The mean specific gravity of tank } 241-\mathrm{AP}-101 \text { grab } \\
\text { samples was } 1.31 \text { slightly exceeding the } 1.3 \text { limit for } \\
\text { source wastes, but it was below the } 1.41 \text { limit for } \\
\text { commingled wastes. The mean tank } 241-\mathrm{AW}-106 \text { result } \\
\text { was below the } 1.3 \text { limit. }\end{array}$ \\
\hline & Energetics & $\begin{array}{l}\text { All samples had an exotherm to endotherm ratio }<1 \text {. No } \\
\text { separable organic layer was observed in any sample. }\end{array}$ \\
\hline & Corrosion & Results were within the corrosion specifications. \\
\hline & \multicolumn{2}{|c|}{ 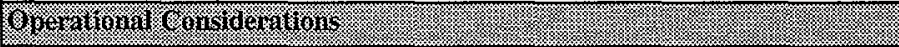 } \\
\hline & $\begin{array}{l}\text { TRU waste } \\
\text { segregation }\end{array}$ & $\begin{array}{l}\text { All analytical results were below the } 100 \mathrm{nCi} / \mathrm{g} \text { TRU } \\
\text { waste segregation limit; therefore, waste does not need to } \\
\text { be segregated for TRU waste reasons. }\end{array}$ \\
\hline & Heat generation & $\begin{array}{l}\text { The estimated tank heat load was far below the operating } \\
\text { specification document limit for tank 241-AP-101. }\end{array}$ \\
\hline & $\begin{array}{l}\text { High phosphate } \\
\text { waste }\end{array}$ & $\begin{array}{l}\text { The waste in tank } 241-\mathrm{AP}-101 \text { is not high in phosphate; } \\
\text { all results were below the } 0.1 M(9,500 \mu \mathrm{g} / \mathrm{mL}) \text { limit. }\end{array}$ \\
\hline
\end{tabular}




\subsection{BEST-BASIS STANDARD INVENTORY ESTIMATE}

Information about the chemical and/or physical properties of tank wastes is used to perform safety analyses, engineering evaluations, and risk assessments associated with waste management activities, as well as to address regulatory issues. Waste management activities include overseeing tank farm operations and identifying, monitoring, and resolving safety issues associated with these operations and with the tank wastes. Disposal activities involve designing equipment, processes, and facilities for retrieving wastes and processing the wastes into a form that is suitable for long-term storage. Chemical inventory information generally is derived using two approaches: 1) component inventories are estimated using the results of sample analyses, and 2) component inventories are predicted using a model based on process knowledge and historical information. The most recent model was developed by Los Alamos National Laboratory (Agnew et al. 1996). Information derived from these different approaches is often inconsistent.

An effort is underway to provide waste inventory estimates that will serve as standard characterization information for the various waste management activities (Hodgson and LeClair 1996). As part of this effort, an evaluation of available chemical information for tank 241-AP-101 was performed. It included the following:

- Characterization results from the July 1993 "bottle-on-a-string" sampling event at a time when $295 \mathrm{~kL}$ (78 kgal) of dilute noncomplexed waste was in the tank. Table 5-5 of DiCenso et al. (1994) summarizes the results from the statistical analysis of data from the sample event.

- Beginning in October 1994, the contents of tank 241-AP-108 were transferred to tank 241-AP-101. Characterization results from the June 1994 grab sampling event for tank 241-AP-108 (Miller 1994, Table 14) were used to provide a composition for this waste.

- In August 1995, 2,450 kL (660 kgal) of waste from tank 241-AP-105 were transferred to tank 241-AP-101. The composition for this waste was taken from the characterization results of the March 1993 "bottle-on-a-string" sampling event given in the Tank Characterization Report for Double-Shell Tank 241-AP-105 (De Lorenzo et al. 1994, Table 5-6).

- The final report for grab samples taken in November 1995 (Esch 1996, Table 1) provides characterization results for tank 241-AP-101 after it received DSSF from tanks 241-AP-105 and 241-AP-108. 
- The 242-A Campaign 95-1 Post Run Document (Guthrie 1996, Table 10) and the final report for the August 1995 tank 241-AW-106 grab samples (Esch $1995)$ provided characterization results for the $1,438 \mathrm{~kL}(380 \mathrm{kgal})$ of DSSF transferred from tank 241-AW-106 to tank 241-AP-101 in March 1996 and January 1997.

- The Hanford Defined Waste (HDW) model document (Agnew et al. 1996) provides tank content estimates derived from the Los Alamos National Laboratory model in terms of component concentrations and inventories. Appendix D provides a complete list of data sources used in this evaluation.

The sample-based data should serve as the basis for the best estimate inventory for tank 241-AP-101 for the following reasons:

1. Although no individual samples of waste currently stored in tank 241-AP-101 exist, data from the tank samples taken in November 1995 and from waste produced in Evaporator Campaign 95-1 can be combined to describe the waste in tank 241-AP-101.

2. The HDW model estimate is outdated because of a large number of waste transfers that have occurred subsequent to the model development.

Tables 3-1 and 3-2 show best-basis inventory estimates for tank 241-AP-101. The data were calculated from sampling data from the 242-A Evaporator (Campaign 95-1), from tank 241-AW-106, and from tank 241-AP-101. Appendix D describes the method used to calculate the inventory from the sampling data.

Table 3-1. Best-Basis Inventory Estimates for Nonradioactive Components in Tank 241-AP-101 as of January 31, 1997. (2 sheets)

\begin{tabular}{|c|c|c|c|}
\hline 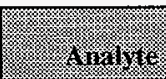 & Wow & 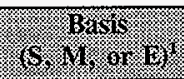 & 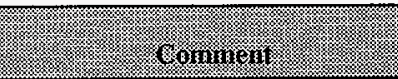 \\
\hline Al & 40,400 & S & \\
\hline $\mathrm{Ca}$ & 237 & $S$ & Campaign 95-1 data not available \\
\hline $\mathrm{Cl}$ & 5,680 & $\mathbf{S}$ & \\
\hline TIC as $\mathrm{CO}_{3}{ }^{2-}$ & $1.13 \mathrm{E}+05$ & $S$ & \\
\hline $\mathrm{Cr}$ & 662 & $S$ & Campaign 95-1 data not available \\
\hline $\bar{F}$ & 8,990 & $S$ & \\
\hline $\mathrm{Fe}$ & 23.5 & $S$ & \\
\hline $\mathrm{K}$ & $1.09 \mathrm{E}+05$ & $S$ & Campaign 95-1 data not available \\
\hline $\mathrm{Na}$ & $6.01 \mathrm{E}+05$ & $S$ & \\
\hline
\end{tabular}


Table 3-1. Best-Basis Inventory Estimates for Nonradioactive Components in Tank 241-AP-101 as of January 31, 1997. (2 sheets)

\begin{tabular}{|c|c|c|c|}
\hline 100 & 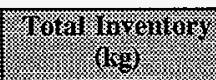 & 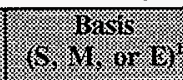 & Cominimin \\
\hline $\mathrm{Ni}$ & 38.5 & $\mathrm{~S}$ & Campaign 95-1 data not available \\
\hline $\mathrm{NO}_{2}^{-}$ & $1.63 \mathrm{E}+05$ & $\mathrm{~S}$ & \\
\hline $\mathrm{NO}_{3}^{-}$ & $5.42 \mathrm{E}+05$ & $\mathrm{~S}$ & . \\
\hline $\mathrm{OH}^{-}$ & $1.75 \mathrm{E}+05$ & $S$ & \\
\hline $\mathrm{Pb}$ & 19.0 & S & Campaign 95-1 data not available \\
\hline $\mathrm{PO}_{4}$ & 4,280 & $\mathrm{~S}$ & $\begin{array}{l}45 \text { percent disparity between } \\
\text { historical and analytical results }\end{array}$ \\
\hline Si & 512 & $\mathrm{~S}$ & Campaign $95-1$ data not available \\
\hline $\mathrm{SO}_{4}$ & 13,400 & S & \\
\hline TOC & 12,400 & $S$ & \\
\hline$\overline{\mathrm{U}_{\text {TOTAL }}}$ & 191 & $S$ & \\
\hline
\end{tabular}

Note:

${ }^{1} \mathrm{~S}=$ sample-based, $\mathrm{M}=\mathrm{HDW}$ model-based, $\mathrm{E}=$ engineering assessment-based.

Table 3-2. Best-Basis Inventory Estimates for Radioactive Components in Tank 241-AP-101 as of January 31, 1997 (Decayed to January 1, 1994).

\begin{tabular}{|c|c|c|c|}
\hline (2) & 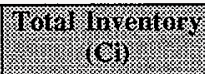 & 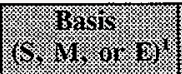 & gonininin \\
\hline${ }^{14} \mathrm{C}$ & 0.744 & $\mathrm{~S}$ & \\
\hline${ }^{90} \mathrm{Sr}$ & 679 & S & \\
\hline${ }^{90} \mathrm{Y}$ & 679 & $\mathbf{S}$ & \\
\hline${ }^{99} \mathrm{Tc}$ & 212 & $\mathbf{S}$ & \\
\hline${ }^{137} \mathrm{Cs}$ & $7.14 \mathrm{E}+05$ & $\mathbf{S}$ & \\
\hline${ }^{137 \mathrm{~m}} \mathrm{Ba}$ & $6.78 \mathrm{E}+05$ & $\mathbf{S}$ & \\
\hline${ }^{154} \mathrm{Eu}$ & 210 & & \\
\hline${ }^{237} \mathrm{~Np}$ & 1.11 & S & Campaign 95-1 data not available \\
\hline${ }^{238} \mathrm{U}$ & 0.0518 & S & Campaign 95-1 data not available \\
\hline${ }^{239 / 240} \mathrm{Pu}$ & 0.713 & $S$ & \\
\hline${ }^{241} \mathrm{Am}$ & 0.843 & $S$ & \\
\hline
\end{tabular}

Note:

${ }^{1} \mathrm{~S}=$ sample-based, $\mathrm{M}=\mathrm{HDW}$ model-based, $\mathrm{E}$ = engineering assessment-based 
HNF-SD-WM-ER-357 Rev. 1

This page intentionally left blank. 


\subsection{RECOMMENDATIONS}

The sampling and analysis activities performed for tank 241-AP-101 have met all the requirements of the safety screening and waste compatibility DQOs. However, the flammability screening is no longer valid. Transfers of waste into the tank have occurred since the flammability screening was performed.

All other issues have been addressed. Because no samples have been taken of the waste currently in the tank, results from earlier samples from tank 241-AP-101 and samples of the waste stream later transferred into the tank were considered. As stated in Section 2, comparison of the analytical results with the safety screening thresholds revealed that one sample did exceed the energetics limit. However, the exotherm for this sample was not reproducible and is considered an anomaly. All other safety issues were satisfied. The specific gravity of tank 241-AP-101 samples slightly exceeded the waste compatibility threshold. However, the overall tank mean was within the compatibility specifications. A characterization best-basis inventory was also developed for the tank contents.

Table 4-1 summarizes the status of Project Hanford Management Contractor (PHMC) TWRS Program review and acceptance of the sampling and analysis results reported in this tank characterization report. Column 1 of Table 4-1 addresses all DQO issues required by sampling and analysis. Column 2 indicates whether the requirements of the DQO were met by the sampling and analysis activities performed and is answered with a "yes" or a "no." Column 3 indicates concurrence and acceptance by the program in PHMC TWRS that is responsible for the DQO that the sampling and analysis activities performed adequately meet the needs of the DQO. A "yes" or "no" indicates acceptance or disapproval of the sampling and analysis information presented in the TCR. If the results and information have not yet been reviewed, "N/R" is shown in the column. If the results and information have been reviewed, but acceptance or disapproval has not been decided, "N/D" is shown.

Table 4-1. Acceptance of Tank 241-AP-101 Sampling and Analysis. ${ }^{1}$

\begin{tabular}{|c|c|c|}
\hline 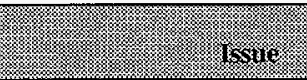 & $\begin{array}{l}\text { Tratintion } \\
\text { portomined }\end{array}$ & 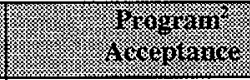 \\
\hline Safety screening DQO & Yes & No (vapor open) \\
\hline Waste compatibility DQO & Yes & Yes \\
\hline
\end{tabular}

Note:

IValid for tank contents as of May 30, 1997.

${ }^{2}$ PHMC TWRS 
Table 4-2 summarizes the status of PHMC TWRS Program review and acceptance of the evaluations and other characterization information contained in this report. The evaluations outlined in this report determine whether the tank is safe, conditionally safe, or unsafe, and whether the tank waste will be compatible with other tank wastes in the double-shell tank system. Column 1 lists the different evaluations performed. Columns 2 and 3 are in the same format as Table 4-1. The manner in which concurrence and acceptance are summarized is also the same as that in Table 4-1.

Table 4-2. Acceptance of Evaluation of Characterization Data and Information for Tank 241-AP-101. ${ }^{1}$

\begin{tabular}{|c|c|c|}
\hline 4 & 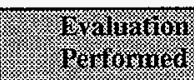 & 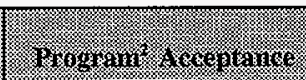 \\
\hline Safety categorization (The tank is safe.) & Yes & No (vapor open) \\
\hline $\begin{array}{l}\text { Waste compatibility assessment (Wastes } \\
\text { are compatible with other wastes in the } \\
\text { double-shell tank system.) }\end{array}$ & Yes & Yes \\
\hline
\end{tabular}

Note:

'Valid for tank contents as of May 30, 1997.

${ }^{2} \mathrm{PHMC}$ TWRS

If tank 241-AP-101 receives waste in the future, the results of this assessment may no longer be valid. 


\subsection{REFERENCES}

Agnew, S. F., J. Boyer, R. A. Corbin, T. B. Duran, J. R. Fitzpatrick, K. A. Jurgensen, T. P. Ortiz, and B. L. Young, 1996, Hanford Tank Chemical and Radionuclide Inventories: HDW Model Rev. 3, LA-UR-96-858, Rev. 0, Los Alamos National Laboratory, Los Alamos, New Mexico.

Bushaw, T. H., 1996, AP-101 DSC Anomaly, (internal memorandum 75763-96-002 to J. G. Kristofzski, January 26), Westinghouse Hanford Company, Richland, Washington.

DeLorenzo, D. S., A. T. DiCenso, L. C. Amato, R. H. Stephens, K. W. Johnson, B. C. Simpson, and T. L. Welsh, 1994, Tank Characterization Report for Double-Shell Tank 241-AP-105, WHC-SD-WM-ER-360, Rev. 0, Westinghouse Hanford Company, Richland, Washington.

DiCenso, A. T., D. S. De Lorenzo, L. C. Amato, J. D. Franklin, R. W. Lambie, and B. C. Simpson, 1994, Tank Characterization Report for Double-Shell Tank 241-AP-101, WHC-SD-WM-ER-357, Rev. 0, Westinghouse Hanford Company, Richland, Washington.

Dukelow, G. T., J. W. Hunt, H. Babad, and J. E. Meacham, 1995, Tank Safety Screening Data Quality Objective, WHC-SD-WM-SP-004, Rev. 2, Westinghouse Hanford Company, Richland, Washington.

Ecology, EPA, and DOE, 1996, Hanford Federal Facility Agreement and Consent Order, as amended, Washington State Department of Ecology, U.S. Environmental Protection Agency, and U.S. Department of Energy, Olympia, Washington.

Esch, R. A., 1995, 60-Day Waste Compatibility Safety Issue and Final Results for Tank 241-AW-106, Grab Samples 6AW-95-1, 6AW-95-2, and 6AW-95-3, WHC-SD-WM-DP-147, Rev. 0, Westinghouse Hanford Company, Richland, Washington.

Esch, R. A., 1996, Final Report for Tank 241-AP-101, Grab Samples 2AP-95-1, 2AP-95-2, $2 A P-95-3,2 A P-95-4,2 A P-95-5$, and 2AP-95-6, WHC-SD-WM-DP-161, Rev. 1, Westinghouse Hanford Company, Richland, Washington.

Fowler, K. D., 1995, Data Quality Objectives for Tank Farms Waste Compatibility Program, WHC-SD-WM-DQO-001, Rev. 1, Westinghouse Hanford Company, Richland, Washington.

Guthrie, M. D., 1996, 242-A Campaign 95-1 Post Run Document, WHC-SD-WM-PE-055, Rev. 0, Westinghouse Hanford Company, Richland, Washington. 
Hanlon, B. M., 1997, Waste Tank Summary Report for Month Ending January 31, 1997, HNF-EP-0182-106, Lockheed Martin Hanford Corporation, Richland, Washington.

Harris, J. P., 1996, Unclassified Operating Specifications for the 241-AN, AP, AW, AT, $A Z$ and SY Tank Farms, OSD-T-151-00007, Rev. H-18, Lockheed Martin Hanford Company, Richland, Washington.

Hodgson, K. M., and M. D. LeClair, 1996, Work Plan for Defining a Standard Inventory Estimate for Wastes Stored in Hanford Site Underground Tanks, WHC-SD-WM-WP-311, Rev. 1, Lockheed Martin Hanford Corporation, Richland, Washington.

Kirkpatrick, T. D., and R. C. Brown, 1984, Basis and Values for Specific Activity and Decay Heat Generation Rates for Selected Radionuclides, SD-RE-TI-131, Rev. 0, Rockwell Hanford Operations, Richland, Washington.

LMHC, 1997, Surveillance Analysis Computer System database, January 21, 1997, Tank Farm Surveillance Engineering, Lockheed Martin Hanford Corporation, Richland, Washington.

Miller, G. L., 1994, Analysis and Characterization of Double-Shell Tank 241-AP-108, WHC-SD-WM-DP-065, Rev. 0, Westinghouse Hanford Company, Richland, Washington.

Public Law 101-510, 1990, "Safety Measures for Waste Tanks at Hanford Nuclear Reservation," Section 3137 of National Defense Authorization Act for Fiscal Year 1991. 
HNF-SD-WM-ER-357 Rev. 1

APPENDIX A

HISTORICAL TANK INFORMATION

A-1 
HNF-SD-WM-ER-357 Rev, 1

This page intentionally left blank. 


\section{APPENDIX A}

\section{HISTORICAL TANK INFORMATION}

Appendix A describes tank 241-AP-101 based on historical information. For this report, historical information includes information about the fill history, waste types, surveillance, or modeling data about the tank. This information can be used to support or challenge conclusions based on sampling and analysis.

This appendix contains the following information:

- Section A1: Current status of the tank including the current waste levels and the stabilization and isolation status.

- Section A2: Information about the tank design.

- Section A3: Process knowledge about the tank, that is, the waste transfer history and the estimated contents of the tank based on modeling data.

- Section A4: Surveillance data for tank 241-AP-101 including surface-level readings and temperatures.

- Section A5: References for Appendix A.

Historical sampling results are included in Appendix B.

\section{A1.0 CURRENT TANK STATUS}

As of January 31, 1997, tank 241-AP-101 contained an estimated 4,224 kL (1,116 kgal) of waste classified as double-shell slurry feed. The liquid volume was estimated using a Food Instrument Corporation gauge and manual tape (LMHC 1997). Table A1-1 shows the volumes of the waste phases found in the tank.

Tank 241-AP-101 is still in service and is categorized as sound. This actively ventilated tank is not on the Watch List (Public Law 101-510). All monitoring systems were in compliance with documented standards as of October 31, 1996 (Hanlon 1996). 
Table A1-1. Estimated Tank Contents as of January $31,1997 .^{1}$

\begin{tabular}{|l|l|l|}
\hline & & \\
\hline & & \\
\hline & & \\
\hline Total waste & 4,224 & 1,116 \\
\hline Supernatant liquid & 4,224 & 1,116 \\
\hline Sludge & 0 & 0 \\
\hline Saltcake & 0 & 0 \\
\hline Drainable interstitial liquid & 0 & 0 \\
\hline Drainable liquid remaining & 4,224 & 1,116 \\
\hline Pumpable liquid remaining & 4,224 & 1,116 \\
\hline
\end{tabular}

Note:

'For definitions and calculation methods refer to Appendix C of Hanlon (1997).

\section{A2.0 TANK DESIGN AND BACKGROUND}

The AP Tank Farm was constructed from 1983 to 1986 in the 200 East Area. The tank farm contains eight double-shell tanks. Each tank has a capacity of 4,390 kL $(1,160 \mathrm{kgal})$, a diameter of $22.9 \mathrm{~m}(75.0 \mathrm{ft})$, and an operating depth of $10.7 \mathrm{~m}(35.2 \mathrm{ft})$. These tanks were designed to hold concentrated supernatant. The maximum design temperature for liquid storage is $149^{\circ} \mathrm{C}\left(300^{\circ} \mathrm{F}\right)$ (Brevick et al. 1995).

Tank 241-AP-101 was constructed with a primary carbon steel liner (heat-treated and stress-relieved), a secondary carbon steel liner (not heat-treated), and a reinforced concrete shell. The bottom of the primary liner is $13 \mathrm{~mm}(0.5 \mathrm{in}$.) thick, the lower portion of the sides is $19 \mathrm{~mm}(0.75 \mathrm{in}$.) thick, the upper portion of the sides is $13 \mathrm{~mm}(0.5 \mathrm{in}$.) thick, and the dome liner is $9.5 \mathrm{~mm}(0.375 \mathrm{in}$.) thick. The secondary liner is $9.5 \mathrm{~mm}(0.375$ in.) thick. The concrete walls are $460 \mathrm{~mm}(1.5 \mathrm{ft})$ thick, and the dome is $380 \mathrm{~mm}(1.25 \mathrm{ft})$ thick. The tank has a flat bottom. The bottom of the primary and secondary liners are separated by an insulating concrete layer. There is a grid of drain slots in the concrete foundation beneath the secondary steel liner. The grid's function is to collect waste that may leak from the tank and divert it to the leak detection well.

Tank 241-AP-101 has 29 risers, ranging in diameter from $100 \mathrm{~mm}$ (4 in.) to $1.1 \mathrm{~m}$ (42 in.), that provide access to the tank and 42 risers that provide access to the annulus. Table A2-1 shows numbers, diameters, and descriptions of the risers (annular risers not included).

Figure A2-1 shows the riser configuration. Eight 100-mm (4-in.)-diameter risers (no. 1 [A-C] 15, 21, 24, 26, and no. 28), three 305-mm (12-in.)-diameter risers (two no. 10s, and 
no. 12), and two 1.1-m (42-in.)-diameter risers (two no. $5 \mathrm{~s}$ ) are available to reach the tank interior. Figure A2-2 shows a tank cross section, the approximate waste level, and a schematic of tank equipment.

Table A2-1. Tank 241-AP-101 Risers. ${ }^{1,2,3,4}$ (2 sheets)

\begin{tabular}{|c|c|c|c|}
\hline Niminer: & (1) & (4) & 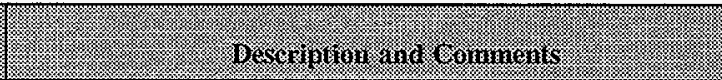 \\
\hline 1 & 10 & 4 & Sludge measurement port \\
\hline 1 & 10 & 4 & Sludge measurement port \\
\hline 1 & 10 & 4 & Sludge measurement port \\
\hline 2 & 10 & 4 & $\begin{array}{l}\text { Automatic liquid indicator tape (Food Instrument Corporation } \\
\text { gauge) }\end{array}$ \\
\hline 3 & 30 & 12 & Supernatant pump (central pump pit) \\
\hline 4 & 30 & 12 & Thermocouple probe \\
\hline 5 & 110 & 42 & Spare, riser plug below grade (manhole) \\
\hline 5 & 110 & 42 & Spare, riser plug below grade (manhole) \\
\hline 7 at $120^{\circ 5}$ & 30 & 12 & Spare, riser plug \\
\hline 7 at $75^{\circ 5}$ & 30 & 12 & Primary tank exhaust \\
\hline 10 & 30 & 12 & Spare, riser plug \\
\hline 10 & 30 & 12 & Spare, riser plug \\
\hline 11 & 110 & 42 & Slurry distributor (central pump pit) \\
\hline 12 & 30 & 12 & Observation port \\
\hline 13 & 30 & 12 & Tank pressure \\
\hline 14 & 10 & 4 & Supernatant return \\
\hline 15 & 10 & 4 & Spare, riser plug \\
\hline 16 & 30 & 12 & Sludge measurement port \\
\hline 16 & 30 & 12 & Sludge measurement port \\
\hline 16 & 30 & 12 & Sludge measurement port \\
\hline 21 & 10 & 4 & Spare, riser plug \\
\hline 22 & 10 & 4 & Sludge measurement port \\
\hline 24 & 10 & 4 & Spare, riser plug \\
\hline 25 & 10 & 4 & High liquid-level sensor \\
\hline 26 & 10 & 4 & Liquid-level indicator (manual tape) \\
\hline
\end{tabular}




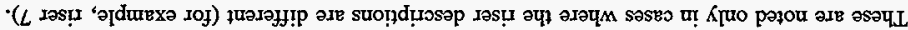

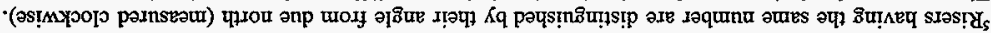

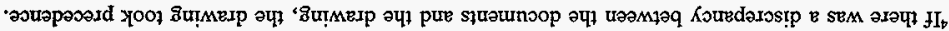

(286I) $\mathrm{HaX}_{\varepsilon}$

(

(†66I) MEZETES :SOION

\begin{tabular}{|c|c|c|c|c|}
\hline & 8̊nId Iəs!̣ 'әIEds & $t$ & OI & 82 \\
\hline & ônyd Iəsṭ 'əreds & † & OI & $\angle Z$ \\
\hline & 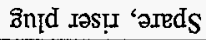 & t & OT & $L Z$ \\
\hline & 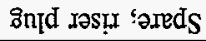 & $t$ & OI & $\angle Z$ \\
\hline 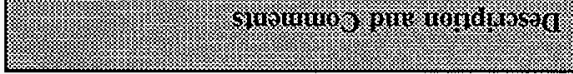 & & sats & (19.8. & 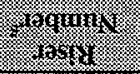 \\
\hline
\end{tabular}

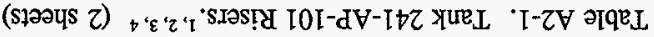


Figure A2-1. Riser Configuration for Tank 241-AP-101.

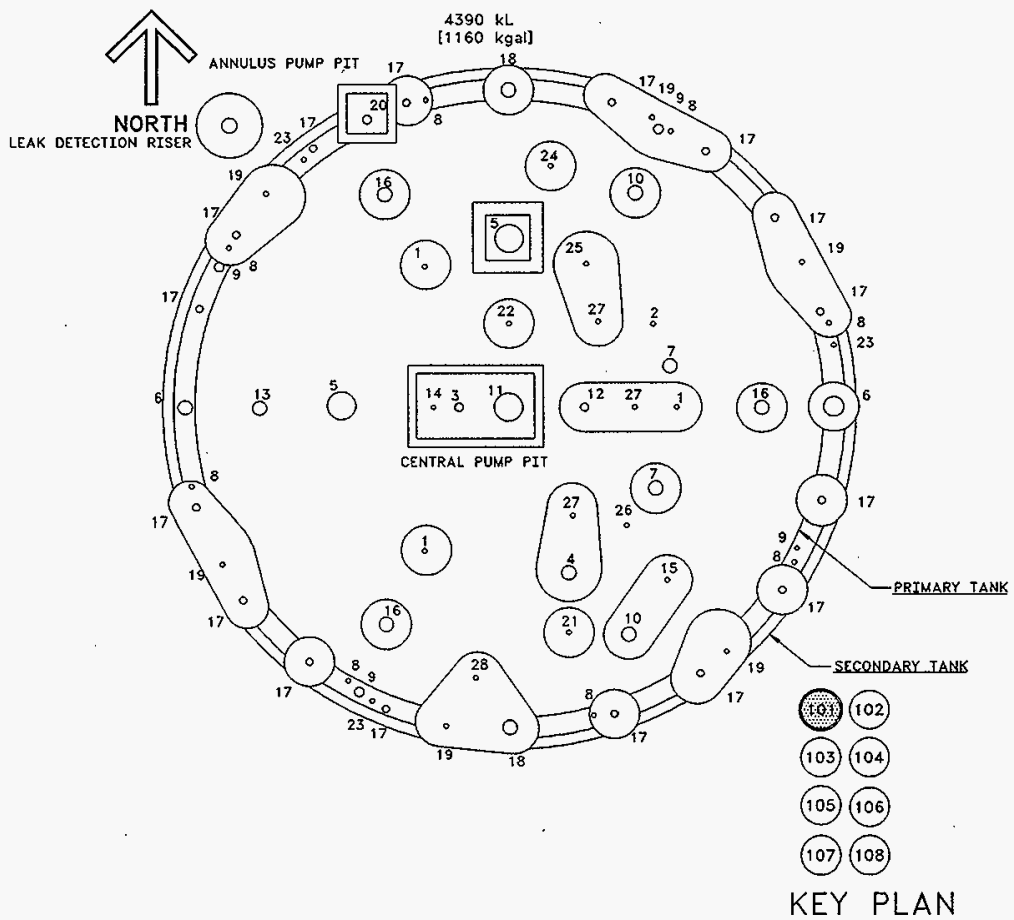




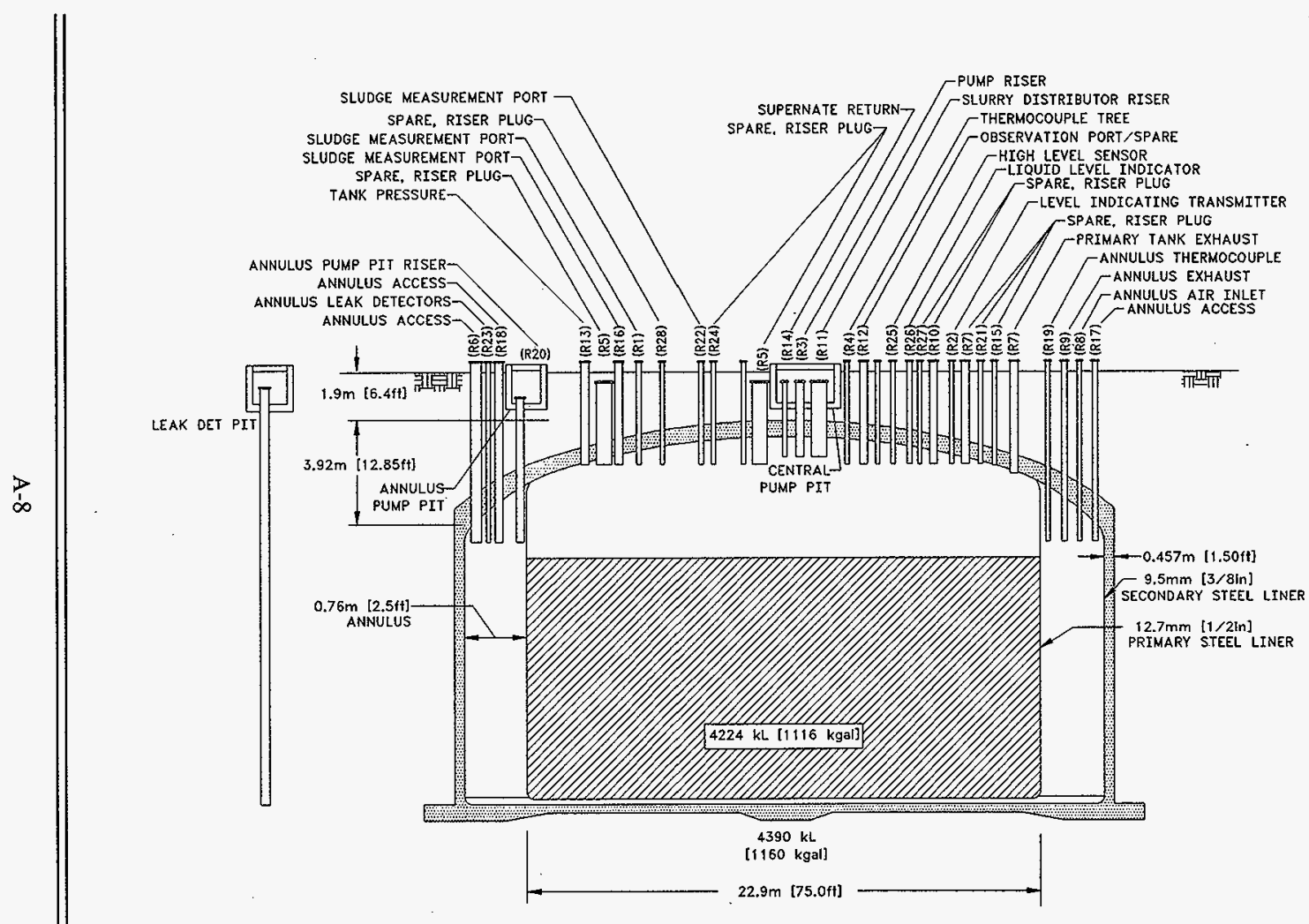

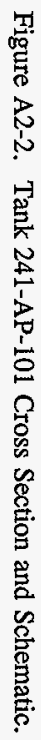




\section{A3.0 PROCESS KNOWLEDGE}

The sections below: 1) provide information about the transfer history of tank 241-AP-101, 2) describe the process wastes that made up the transfers, and 3) give an estimate of the current tank contents based on transfer history.

\section{A3.1 WASTE TRANSFER HISTORY}

Tank 241-AP-101 first received about $68 \mathrm{~kL}$ (18 kgal) of unknown waste (likely an addition of water) during the fourth quarter of 1986 . The tank received a small transfer of $4 \mathrm{~kL}$ (1 kgal) of PUREX decladding supernatant and $72 \mathrm{~kL}$ (19 kgal) of an unknown waste during the third quarter of 1987. During the second quarter of 1988, the tank received the first of a series of transfers of PUREX ammonia scrubber feed (PASF) from the PUREX Plant. During 1988 and 1989, the tank received a total of about 7,301 kL (1,929 kgal) of PASF. Flush water was sent to the tank in 1988 and 1989. From September through December 1988 , more than $2,737 \mathrm{~kL}$ ( $723 \mathrm{kgal})$ of waste was transferred from tank 241-AP-101 to tank 241-AW-102 (242-A Evaporator feed tank) for processing during Evaporator Campaign 89-1 (Jonas 1989). Also during the fourth quarter of 1988, about 2,188 kL (578 kgal) was transferred from tank 241-AP-101 to tank 241-AP-103.

During the fourth quarter of 1989 , tank 241-AP-101 received a transfer of about 2,332 kL (616 kgal) of waste from tank 241-AP-103. This waste consisted of the waste transferred from tank 241-AP-101 to tank 241-AP-103 during the previous year and some additional PASF and flush water.

No further transfer activity was recorded for this tank until August 1994 when the Evaporator Campaign 94-2 began (Guthrie 1995). Near the beginning of the campaign, about $2,816 \mathrm{~kL}$ (744 kgal) of waste was transferred from tank 241-AP-101 to tank 241-AW-102 near the beginning of the campaign. In October, about 1,075 kL (284 kgal) of supernatant was added to tank 241-AP-101 from tank 241-AP-108.

Subsequently about $1,707 \mathrm{~kL}$ (451 kgal) was transferred from tank 241-AP-101 to tank 241-AW-102.

During January 1995, tank 241-AP-101 received a transfer of about 2,896 kL (765 kgal) of dilute noncomplexed waste from tank 241-AP-108. Subsequently about 3,164 kL ( $836 \mathrm{kgal}$ ) of waste was transferred from tank 241-AP-101 to tank 241-AP-107 leaving a total waste volume in tank 241 -AP-101 of about $295 \mathrm{~kL}$ (78 kgal). During August 1995, tank 241-AP-101 received 2,498 kL (660 kgal) of DSSF from tank 241-AP-105. During March 1996, a transfer of $1,158 \mathrm{~kL}$ (306 kgal) of dilute noncomplexed waste was sent tank 241-AP-101 from tank 241-AW-106, and during January 1997, another $280 \mathrm{~kL}$ (74 kgal) transfer from 241-AW-106 occurred. This waste consisted of DSSF produced during the 242-A Evaporator Campaign 95-1 (Guthrie 1996). 
Table A3-1 summarizes major waste transfers into tank 241-AP-101.

Table A3-1. Tank 241-AP-101 Transfer History.

\begin{tabular}{|c|c|c|c|c|c|}
\hline 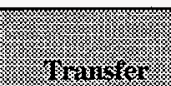 & Thransfer: & & & Esta & $\frac{11}{110}$ \\
\hline 503142 & ocstination & 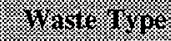 & rine ronird & (6) & (Igai: \\
\hline PUREX plant & & Supernatant & 1987 & 4 & 1 \\
\hline Unknown & & Unknown & 1987 & 72 & 19 \\
\hline PUREX plant & & PASF & 1988 to 1989 & 7,301 & 1,929 \\
\hline & 241-AW-102 & Supernatant & 1988 & $-2,737$ & -723 \\
\hline $\begin{array}{l}\text { Miscellaneous } \\
\text { sources }\end{array}$ & & Flush water & 1988 to 1989 & 227 & 60 \\
\hline 241-AP-103 & & Supernatant & 1989 & 2,332 & 616 \\
\hline & 241-AW-102 & Supernatant & 1994 & $-4,523$ & $-1,195$ \\
\hline 241-AP-108 & & Supernatant & 1994 to 1995 & 3,970 & 1,049 \\
\hline & 241-AP-107 & Supernatant & 1995 & $-3,164$ & -836 \\
\hline 241-AP-105 & & Supernatant & 1995 & 2,498 & 660 \\
\hline $241-A W-106$ & & Supernatant & 1996 to 1997 & 1,438 & 380 \\
\hline
\end{tabular}

Note:

${ }^{1}$ Because only major transfers are listed, the sum of these transfers will not equal the current waste tank volume. 


\section{A3.2 HISTORICAL ESTIMATION OF TANK CONTENTS}

The historical transfer data used for this estimate are from the following sources:

- Waste Status and Transaction Record Summary for the Southwest Quadrant of the Hanford 200 East Area (WSTRS) (Agnew et al. 1996). This document is a tank-by-tank quarterly summary spreadsheet of waste transactions.

- Hanford Tank Chemical and Radionuclide Inventories: HDW Model Rev 4 (Agnew et al. 1997). This document contains the HDW list, the Supernatant Mixing Model, and the Tank Layer Model).

- The Historical Tank Content Estimate for the Northeast Quadrant of the Hanford 200 East Area (Brevick et al. 1996), Historical Tank Content Estimate for the Northwest Quadrant of the Hanford 200 West Area (Brevick et al. 1997a), Historical Tank Estimate for the Southeast Quadrant of the Hanford 200 East Area (Brevick et al. 1997b), and the Historical Tank Content Estimate for the Southwest Quadrant of the Hanford 200 West Area (Brevick et al. 1997c) compile and summarize much of the process history, design, and technical information regarding the underground waste storage tanks in the 200 Areas.

- Tank Layer Model (TLM). The TLM defines the sludge and saltcake layers in each tank using waste composition and waste transfer information.

- Supernatant Mixing Model (SMM). This is a subroutine within the HDW model that calculates the volume and composition of certain supernatant blends and concentrates.

Using these records, the TLM defines the sludge and saltcake layers in each tank. The SMM uses information from the WSTRS and the TLM to describe the supernatants and concentrates in each tank. Together the WSTRS, TLM, and SMM determine each tank's inventory estimate. These model predictions are considered estimates that require further evaluation using analytical data.

This sources are combined to produce a historical tank inventory estimate for each of 177 tanks. These predictions have not been validated and should be used with caution. In some cases, the available data are incomplete, thereby reducing the reliability of the transfer data and the modeling results derived from them. Therefore, these predictions can be considered estimates that require further evaluation using analytical data.

These models have not been updated for waste transfers since January 1, 1994. The volume of waste in tank 241-AP-101 was $295 \mathrm{~kL}$ (78 kgal) in January 1995, and the current volume is $4,225 \mathrm{~kL}(1,116 \mathrm{kgal})$. Therefore, the HDW model estimate for tank 241-AP-101 is not given here because it does not represent the waste currently in the tank. 


\section{A4.0 SURVEILLANCE DATA}

Tank 241-AP-101 surveillance data consist of surface-level measurements (liquid and solid), temperature monitoring inside the tank (waste and headspace), and leak detection well monitoring for radioactive liquids outside the primary tank. Liquid-level measurements indicate major leaks into or out of the tank. Leak detection systems within the annulus of the tank will detect leaks from the primary tank. These data provide the basis for determining tank integrity.

\section{A4.1 SURFACE LEVEL READINGS}

Waste surface-level monitoring is performed with a Food Instrument Corporation gauge (riser 2) and a manual tape (riser 26). Because this is an active tank, the surface level is continually subject to change. The waste surface level on January 14, 1997, was $10.31 \mathrm{~m}$ (405.8 in.) by an automatic Food Instrument Corporation gauge (LMHC 1997). Figure A4-1 is a graph of the volume measurements.

\section{A4.2 INTERNAL TANK TEMPERATURES}

Temperature data for tank 241-AP-101 are recorded by 18 thermocouples on one thermocouple tree located in riser 4. Data are recorded weekly. Temperature data were evaluated from the Surveillance Analysis Computer System (LMHC 1997) recorded from July 1989 to January 1997 . Not all thermocouples have data covering the entire period. Currently, data are only reported for thermocouples $1,3,5,7,11$, and 17. The average temperature during this period was $17^{\circ} \mathrm{C}\left(62^{\circ} \mathrm{F}\right)$ with a minimum of $12{ }^{\circ} \mathrm{C}\left(53^{\circ} \mathrm{F}\right)$ and a maximum of $23{ }^{\circ} \mathrm{C}\left(74^{\circ} \mathrm{F}\right)$.

The minimum temperature on January 6,1997 , was $17.9^{\circ} \mathrm{C}\left(64.2^{\circ} \mathrm{F}\right)$ at thermocouple 17 ; the maximum temperature on the same date was $19.8^{\circ} \mathrm{C}\left(67.8^{\circ} \mathrm{F}\right)$ at thermocouple 11 . Figure A4-2 shows a graph of the weekly high temperatures.

\section{A4.3 TANK 241-AP-101 PHOTOGRAPHS}

No interior photographs are available. 
Figure A4-1. Tank 241-AP-101 Level History.

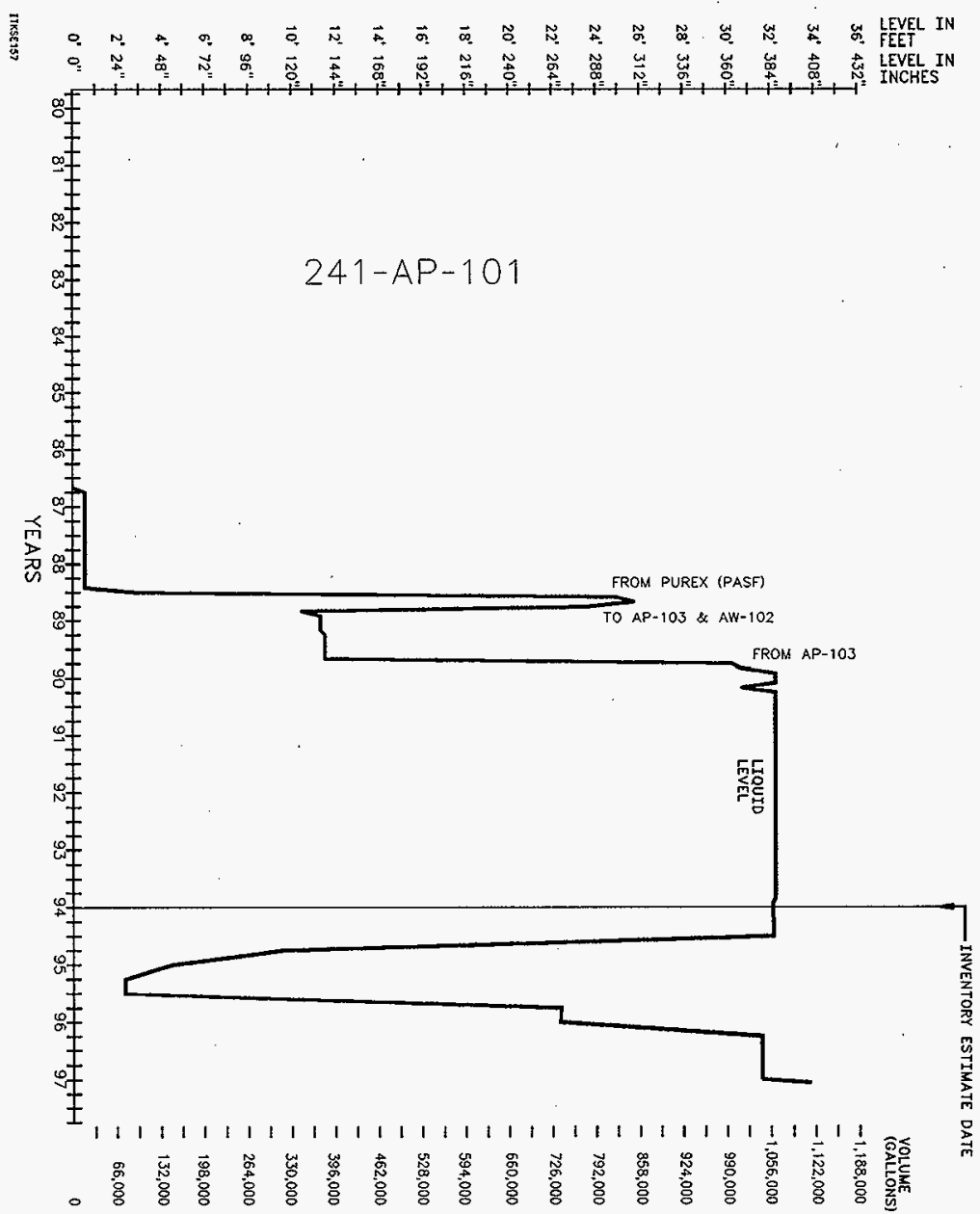


HNF-SD-WM-ER-357 Rev. 1

Figure A4-2. Tank 241-AP-101 High Temperature Plot.

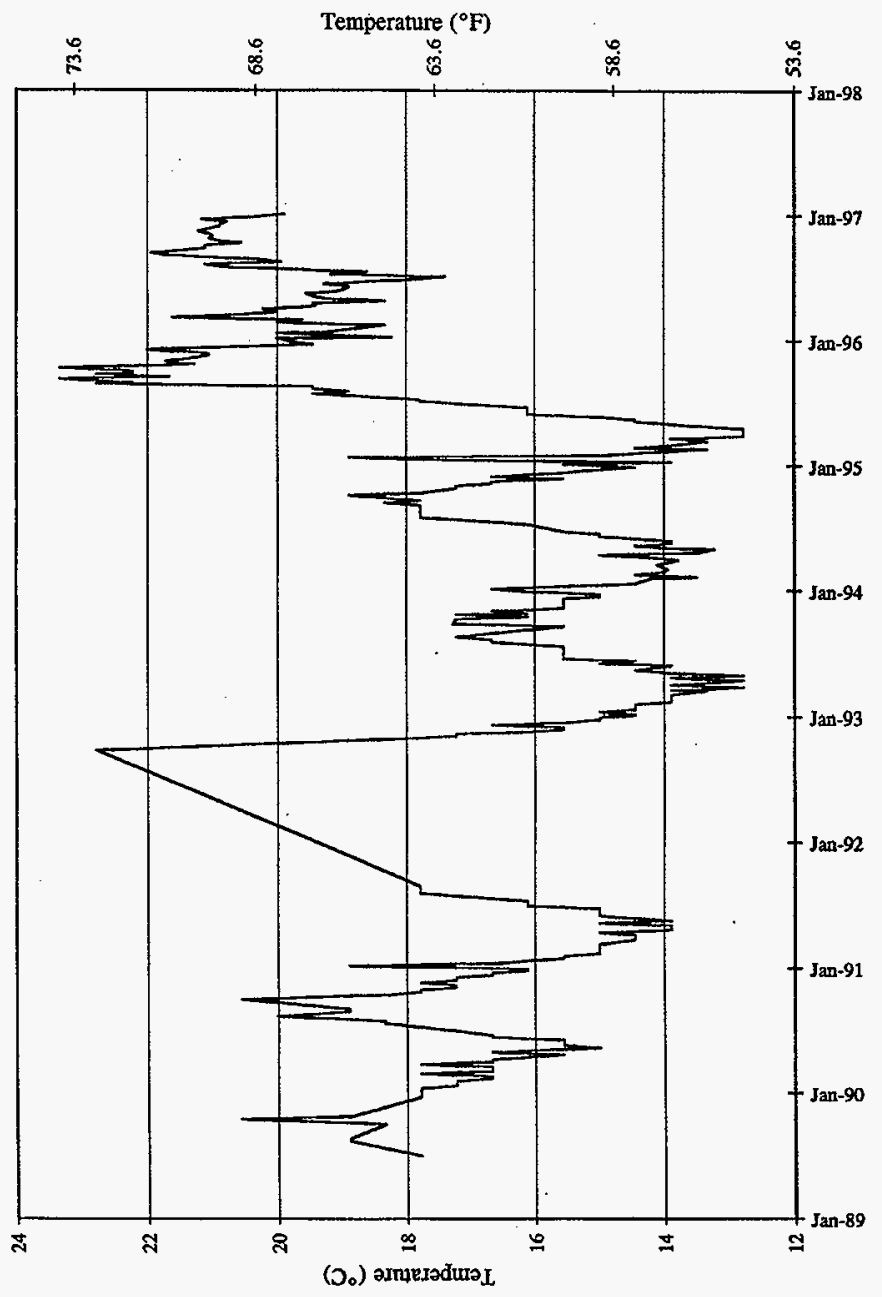




\section{A5.0 APPENDIX A REFERENCES}

Agnew, S. F., R. A. Corbin, T. B. Duran, K. A. Jurgensen, T. P. Ortiz, and B. L. Young, 1996, Waste Status and Transaction Record Summary for the Southeast Quadrant of the Hanford 200 East Area, WHC-SD-WM-TI-689, Rev. 1, Westinghouse Hanford Company, Richland, Washington.

Agnew, S. F., J. Boyer, R. A. Corbin, T. B. Duran, J. R. Fitzpatrick, K. A. Jurgensen, T. P. Ortiz, and B. L. Young, 1997, Hanford Tank Chemical and Radionuclide Inventories: HDW Model Rev. 4, LA-UR-96-3680, Rev. 0, Los Alamos National Laboratory, Los Alamos, New Mexico.

Brevick, C. H., L. A. Gaddis, and S. D. Consort, 1995, Supporting Document for the Historical Tank Content Estimate for AP Tank Farm - Volumes I and 2, WHC-SD-WM-ER-315, Rev. 0, Westinghouse Hanford Company, Richland, Washington.

Brevick, C. H., J. W. Funk, and J. L. Stroup, 1996, Historical Tank Content Estimate for the Northeast Quadrant of the Hanford 200 East Area, WHC-SD-WM-ER-349, Rev. 1, Westinghouse Hanford Company, Richland, Washington.

Brevick, C. H., K. L. Ewer, J. W. Funk, R. G. Hale, G. A. Lisle, C. V. Salois, and M. R. Humphrey, 1997a, Historical Tank Content Estimate for the Northwest Quadrant of the Hanford 200 West Area, HNF-SD-WM-ER-351, Rev. 1, Fluor Daniel Northwest, Inc., Richland, Washington.

Brevick, C. H., J. W. Funk, R. G. Hale, G. A. Lisle, C. V. Salois, and M. R. Umphrey, 1997b, Historical Content Estimate for the Southeast Quadrant of the Hanford 200 East Area, HNF-SD-WM-ER-530, Rev. 1, Fluor Daniel Northwest, Inc., Richland, Washington.

Brevick, C. H., K. L. Ewer, J. W. Funk, R. G. Hale, G. A. Lisle, C. V. Salois, and M. R. Umphrey, 1997c, Historical Tank Content Estimate for the Southwest Quadrant of the Hanford 200 West Area, HNF-SD-WM-ER-352, Rev. 1, Fluor Daniel Northwest, Inc., Richland, Washington.

Guthrie, M. D., 1995, 242-A Campaign 94-2 Post Run Document, WHC-SD-WM-PE-054, Rev. 0, Westinghouse Hanford Company, Richland, Washington. 
Guthrie, M. D., 1996, 242-A Campaign 95-1 Post Run Document, WHC-SD-WM-PE-055, Rev. 0, Westinghouse Hanford Company, Richland, Washington.

Hanlon, B. M., 1997, Waste Tank Summary Report for Month Ending January 31, 1997, WHC-EP-0182-106, Westinghouse Hanford Company, Richland, Washington.

Jonas, A. L., 1989, 242-A Evaporator FY 1989 Campaign Run 89-1 Post Run Document, WHC-SD-WM-PE-037, Rev. 0, Westinghouse Hanford Company, Richland, Washington.

KEH, 1982, "Plan Tank Penetrations 241-AP-101 and 103," Drawing H-2-90538, Rev. 1, Kaiser Engineers Hanford, Richland, Washington.

LMHC, 1997, SACS: Surveillance Analysis Computer System, In: SYBASE/Visual BASIC (Mainframe). Available: HLAN, Lockheed Martin Hanford Corporation, Richland, Washington.

Public Law 101-510, 1990, "Safety Measures for Waste Tanks at Hanford Nuclear Reservation," Section 3137 of National Defense Authorization Act for Fiscal Year 1991.

Salazar, B. E., 1994, Double-Shell Underground Waste Storage Tanks Riser Survey, WHC-SD-RE-TI-093, Rev. 4, Westinghouse Hanford Company, Richland, Washington.

WHC, 1994, "Piping Plan Tank 101," Drawing H-2-90553, Rev. 4, Westinghouse Hanford Company, Richland, Washington. 
HNF-SD-WM-ER-357 Rev. 1

APPENDIX B

SAMPLING OF TANK 241-AP-101

B-1 
HNF-SD-WM-ER-357 Rev. 1

This page intentionally left blank. 


\section{APPENDIX B}

\section{SAMPLING OF TANK 241-AP-101}

Appendix B provides sampling and analysis information for each known sampling event for tank 241-AP-101, and it assesses the November 1995 grab sampling results.

- Section B1: Tank Sampling Overview

- Section B2: Analytical Results

- Section B3: Assessment of Characterization Results

- $\quad$ Section B4: References for Appendix B

\section{B1.0 TANK SAMPLING OVERVIEW}

This section describes the November 1995 sampling and analysis event for tank 241-AP-101 and two other sampling events used in the characterization of this tank. During November 1995, six supernatant grab samples and one field blank were taken to satisfy the requirements of the Tank Safety Screening Data Quality Objective (Dukelow et al. 1995) and the Data Quality Objectives for Tank Farms Waste Compatibility Program (Fowler 1995). The sampling and analysis were performed in accordance with the Tank 241-AP-101 Grab Sampling and Analysis Plan (Esch 1995b).

After the November 1995 sampling, 1,438 kL (380 kgal) of evaporated waste were transferred from tank 241-AW-106 to tank 241-AP-101 (March 1996 and January 1997). A sample obtained from the 242-A Evaporator in July 1995 during Campaign $95-1$ and a grab sample taken from tank 241-AW-106 on August 24, 1995, provide characterization data for the evaporator slurry waste. Section B1.2 describes these two sampling events. For further discussion of the sampling and analysis procedures, refer to the Tank Characterization Reference Guide (DeLorenzo et al. 1994). 


\section{B1.1 TANK 241-AP-101 1995 GRAB SAMPLING}

\section{B1.1.1 Description of Sampling Event}

Six supernatant grab samples and one field blank were collected from tank 241-AP-101 on November 10 and 13,1995, using the bottle-on-a-string method. Three supernatant samples each were obtained from risers 1 at $210^{\circ}(\mathrm{SW})$ and 1 at $330^{\circ}(\mathrm{NW})$ at depths specified by the sampling and analysis plan (Esch 1995b). All samples were received by the 222-S Laboratory on the same day the samples were collected. Table B1-1 summarizes applicable DQOs and sampling and analysis requirements for this sampling event.

Before collecting the grab samples, the tank headspace was sampled below risers $1 \mathrm{SW}$ and $1 \mathrm{NW}$ and analyzed for the presence of flammable gases as required by Esch (1995a).

Table B1-1. Integrated Data Quality Objective Requirements for Tank 241-AP-101. ${ }^{1}$

\begin{tabular}{|c|c|c|c|}
\hline 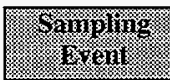 & 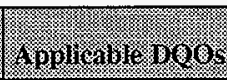 & 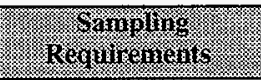 & 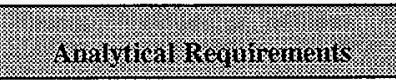 \\
\hline \multirow[t]{2}{*}{$\begin{array}{l}1995 \text { grab } \\
\text { sampling }\end{array}$} & $\begin{array}{l}\text { Safety screening } \\
\text { (Dukelow et al. } \\
1995 \text { ) }\end{array}$ & $\begin{array}{l}\text { Vertical profiles from } \\
\text { two widely spaced } \\
\text { risers }\end{array}$ & $\begin{array}{l}\text { - Energetics } \\
\text { - Moisture content } \\
\text { - Total alpha activity } \\
\text { - Specific gravity } \\
\text { - Visual check for organic layer }\end{array}$ \\
\hline & $\begin{array}{l}\text { Waste } \\
\text { compatibility } \\
\text { (Fowler 1995) }\end{array}$ & $\begin{array}{l}\text { Grab samples from } \\
\text { varying depths }\end{array}$ & $\begin{array}{l}\text { - Energetics } \\
\text { - Moisture content } \\
\text { - Misual check for organic layer } \\
\text { - Anions by IC } \\
\text { - Radionuclides } \\
\text { - TIC, TOC } \\
\text { - Hydroxide } \\
\text { - Specific gravity } \\
\text { - pH } \\
\text { - Percent solids }\end{array}$ \\
\hline $\begin{array}{l}\text { Combustible } \\
\text { gas meter } \\
\text { reading }\end{array}$ & Safety screening & $\begin{array}{l}\text { Flammable gas } \\
\text { concentration } \\
\text { measured in the tank } \\
\text { headspace }\end{array}$ & - Percent of LFL \\
\hline
\end{tabular}

Note:

${ }^{1}$ Esch (1995a) 


\section{B1.1.2 Sample Handling}

The samples were prepared for analysis at the 222-S Laboratory. All samples were visually inspected for color, clarity, solids content, and the presence of a potential organic layer. All samples (except for the field blank) were described as yellow and clear. Two 20-mL subsamples were then removed from each sample for analysis; the remainder of each sample was archived. Table B1-2 relates sample numbers used in the field with sample numbers assigned in the laboratory. It also shows the riser location and height from which each sample was obtained. Note that sample 1 AP-95-1 was actually taken from a lower depth than sample 1AP-95-2. In addition, over-the-top dose rate readings and data from the visual inspection conducted at the laboratory are shown.

Table B1-2. Grab Sample Descriptions. ${ }^{1}$

\begin{tabular}{|c|c|c|c|c|c|c|c|}
\hline 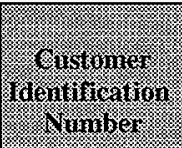 & 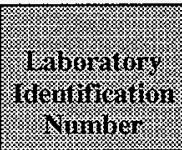 & 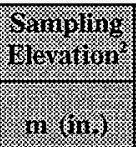 & 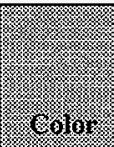 & gramits: & solitas: & $\begin{array}{l}\text { Privinal } \\
\text { Orgounice }\end{array}$ & 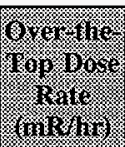 \\
\hline (1. & : & \multicolumn{6}{|c|}{ (Riker } \\
\hline $1 \mathrm{AP}-95-1$ & S95T003717 & $3.40(134)$ & Yellow & Clear & None & None & 3,300 \\
\hline $1 \mathrm{AP}-95-2$ & S95T003718 & $6.78(267)$ & Yellow & Clear & None & None & 3,500 \\
\hline $1 \mathrm{AP}-95-3$ & $\$ 95 T 003719$ & $0.25(10)$ & Yellow & Clear & None & None & 3,500 \\
\hline $\begin{array}{l}1 \text { AP-95-7 } \\
\text { (Field blank) }\end{array}$ & S95T003720 & $10.4(410)$ & Colorless & Clear & None & None & 0.5 \\
\hline \multicolumn{8}{|c|}{ 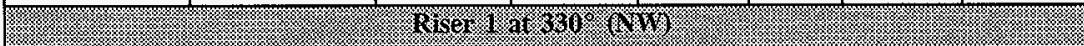 } \\
\hline 1AP-95-4 & S95T003725 & $6.78(267)$ & Yellow & Clear & None & None & 3,000 \\
\hline $1 \mathrm{AP}-95-5$ & S95T003726 & $3.40(134)$ & Yellow & Clear & None & None & 3,400 \\
\hline $1 \mathrm{AP}-95-6$ & S95T003727 & $0.25(10)$ & Yellow & Clear & None & None & 3,800 \\
\hline
\end{tabular}

Notes:

$\mathrm{mR} / \mathrm{hr}=\operatorname{millirad}$ per hour

${ }^{1}$ Esch (1996)

${ }^{2}$ Above the tank bottom

\section{B1.1.3 Sample Analysis}

The grab samples were analyzed for safety screening and waste compatibility assessments. As noted in Table B1-1, the safety screening DQO required analyses for energetics by DSC, weight percent water by thermogravimetric analysis (TGA), fissile content by total alpha 
analysis using an alpha proportional counter, and specific gravity. The analyses required by the waste compatibility DQO included all primary safety screening analytes (except total alpha activity) and the following: total inorganic carbon (TIC) and TOC by furnace oxidation; hydroxide by potentiometric titration; $\mathrm{pH} ;{ }^{137} \mathrm{Cs}$ by gamma energy analysis (GEA); ${ }^{90} \mathrm{Sr}$ by beta proportional counting; ${ }^{241} \mathrm{Am}$ and ${ }^{239} / 240 \mathrm{Pu}$ by alpha proportional counting; aluminum, iron, and sodium by inductively coupled plasma spectroscopy (ICP); anions ( $\mathrm{Cl}^{-}$, $\mathrm{F}, \mathrm{NO}_{3}{ }^{-}, \mathrm{NO}_{2}{ }^{-}, \mathrm{PO}_{4}{ }^{3-}, \mathrm{SO}_{4}{ }^{2-}$ ) by ion chromatography (IC); and centrifugation for volume percent solids. The tank vapor phase was screened in the field by means of a combustible gas meter.

All reported analyses were performed directly on subsamples according to approved laboratory procedures. Because of the absence of solids in the samples, the volume percent solids by centrifugation test was not performed. Specific gravity was not performed in duplicate for subsample S95T003724 because of an insufficient amount of sample material. Laboratory quality control (QC) checks included, where appropriate, laboratory control standards, matrix spikes, duplicate analyses, and blanks. Section B3.2 shows an assessment of the QC procedures and data.

Table B1-3 lists the sample numbers and applicable analyses.

Table B1-3. Sample Analysis Summary. ${ }^{1}$ (2 sheets)

\begin{tabular}{|c|c|c|}
\hline 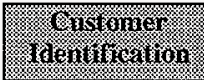 & 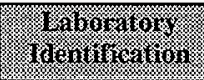 & \\
\hline : & : & 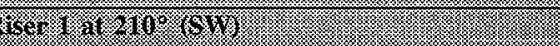 \\
\hline \multirow[t]{2}{*}{$1 \mathrm{AP}-95-1$} & S95T003721 & DSC, TGA, TIC/TOC, ICP, IC, pH, OH', SpG \\
\hline & S95T003731 & GEA, ${ }^{239 / 240} \mathrm{Pu},{ }^{90} \mathrm{Sr},{ }^{241} \mathrm{Am}$, total alpha activity \\
\hline \multirow[t]{2}{*}{$1 \mathrm{AP}-95-2$} & S95T003722 & DSC, TGA, TIC/TOC, ICP, IC, $\mathrm{pH}, \mathrm{OH}^{-}, \mathrm{SpG}$ \\
\hline & S95T003732 & GEA, ${ }^{239 / 240} \mathrm{Pu},{ }^{90} \mathrm{Sr},{ }^{241} \mathrm{Am}$, total alpha activity \\
\hline \multirow[t]{2}{*}{$1 \mathrm{AP}-95-3$} & S95T003723 & DSC, TGA, TIC/TOC, ICP, IC, $\mathrm{pH}, \mathrm{OH}, \mathrm{SpG}$ \\
\hline & S95T003733 & GEA, ${ }^{239 / 240} \mathrm{Pu},{ }^{90} \mathrm{Sr},{ }^{241} \mathrm{Am}$, total alpha activity \\
\hline \multirow{2}{*}{$\begin{array}{l}\text { 1AP-95-7 } \\
\text { (Field blank) }\end{array}$} & S95T003724 & DSC, TGA, TIC/TOC, ICP, IC, $\mathrm{pH}, \mathrm{OH}^{-}, \mathrm{SpG}$ \\
\hline & S95T003734 & GEA, ${ }^{239 / 240} \mathrm{Pu},{ }^{90} \mathrm{Sr},{ }^{241} \mathrm{Am}$, total alpha activity \\
\hline
\end{tabular}


Table B1-3. Sample Analysis Summary. ${ }^{1}$ (2 sheets)

\begin{tabular}{|c|c|c|}
\hline 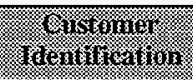 & Theritificatiton & Nonagk \\
\hline (3) & 1 & 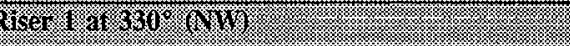 \\
\hline \multirow[t]{2}{*}{$1 \mathrm{AP}-95-4$} & S95T003728 & DSC, TGA, TIC/TOC, ICP, IC, pH, OH', SpG \\
\hline & S95T003735 & GEA, ${ }^{239 / 240} \mathrm{Pu},{ }^{90} \mathrm{Sr},{ }^{241} \mathrm{Am}$, total alpha activity \\
\hline \multirow[t]{2}{*}{$1 \mathrm{AP}-95-5$} & S95T003729 & DSC, TGA, TIC/TOC, ICP, IC, pH, OH-, SpG \\
\hline & S95T003736 & GEA, ${ }^{239 / 240} \mathrm{Pu},{ }^{90} \mathrm{Sr},{ }^{241} \mathrm{Am}$, total alpha activity \\
\hline \multirow[t]{2}{*}{ 1AP-95-6 } & S95T003730 & DSC, TGA, TIC/TOC, ICP, IC, pH, OH', SpG \\
\hline & S95T003737 & GEA, ${ }^{239 / 240} \mathrm{Pu},{ }^{90} \mathrm{Sr},{ }^{241} \mathrm{Am}$, total alpha activity \\
\hline
\end{tabular}

Notes:

SpG $=$ specific gravity

${ }^{1}$ Esch (1996)

\section{B1.2 EVAPORATOR SLURRY SAMPLING}

\section{B1.2.1 242-A Evaporator Campaign 95-1 Sampling}

Tank 241-AW-106 was one of four tanks providing feed for Evaporator Campaign 95-1, and it also acted as the slurry receiver for the Evaporator Campaign 95-1 (Guthrie 1996). A sample (T2270) was drawn of the slurry product on July 21, 1995, and it was subsequently analyzed in accordance with the 242-A Evaporator Sample Schedule for Campaign 95-1 (Le 1995). The over-the-top dose rate was 1,250 millirad per hour, and the settled percent solids was 3.4 volume percent. The sample was analyzed for the following: DSC, pH, specific gravity, TIC, TOC, total carbon, fluoride, nitrite, nitrate, phosphate, sulfate, hydroxide, ammonia, aluminum, sodium, total beta activity, total alpha activity, uranium, ${ }^{3} \mathrm{H},{ }^{14} \mathrm{C},{ }^{60} \mathrm{Co},{ }^{79} \mathrm{Se},{ }^{89 / 90} \mathrm{Sr},{ }^{94} \mathrm{Nb},{ }^{99} \mathrm{Tc},{ }^{106} \mathrm{RuRh},{ }^{129} \mathrm{I},{ }^{134} \mathrm{Cs},{ }^{137} \mathrm{Cs},{ }^{144} \mathrm{Ce},{ }^{154} \mathrm{Eu},{ }^{155} \mathrm{Eu}$, ${ }^{226} \mathrm{Ra},{ }^{237} \mathrm{~Np},{ }^{238} \mathrm{Pu},{ }^{239 / 240} \mathrm{Pu},{ }^{241} \mathrm{Am}$, and ${ }^{244} \mathrm{Cm}$.

\section{B1.2.2 Tank 241-AW-106 August 1995 Grab Sampling}

Three grab samples (one liquid and two sludge) were taken from riser 16B of tank 241-AW-106 on August 24, 1995 (Esch 1995a). The samples were collected and analyzed to support the waste compatibility safety program and to resolve process control questions from the most recent evaporator campaign. Because only the supernatant sample (sample 6AW-95-1) represents the waste transferred to tank 241-AP-101 in March 1996 and 


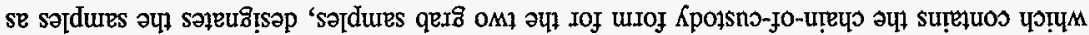

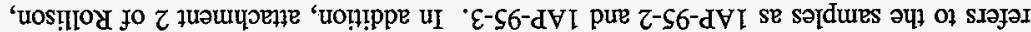

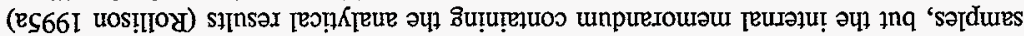

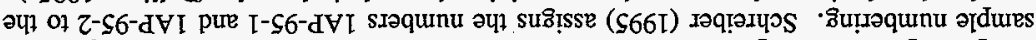

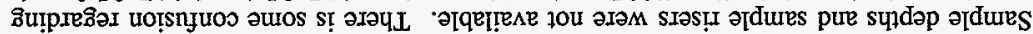

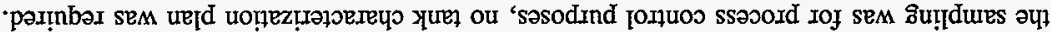

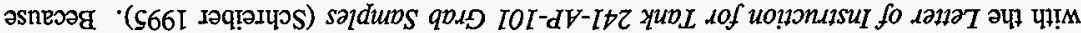

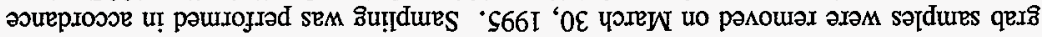

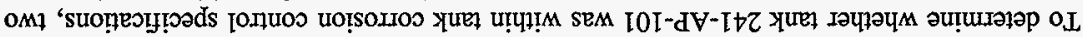

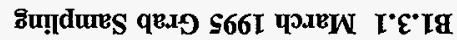

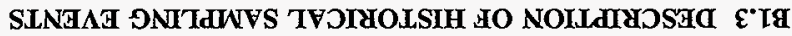

(9S66I) घos解

$: 210 \mathrm{~N}$

\begin{tabular}{|c|c|c|}
\hline 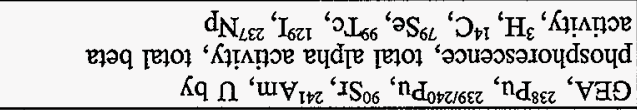 & LI0Z00LS6S & \\
\hline 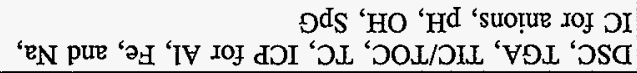 & 9L0Z00LS6S & $I-S 6-M \vee 9$ \\
\hline $8 \mathrm{OS}$ & & \\
\hline 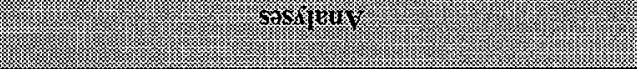 & (106) & 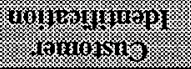 \\
\hline
\end{tabular}

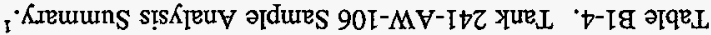

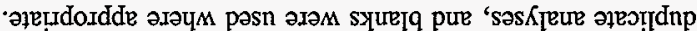

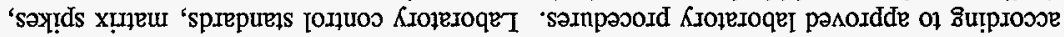

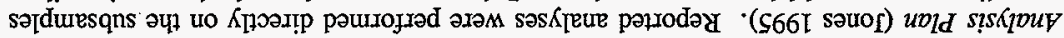

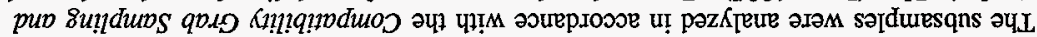

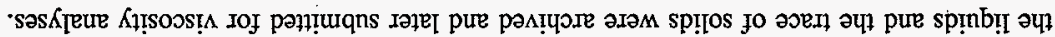

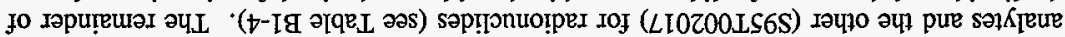

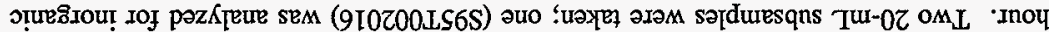

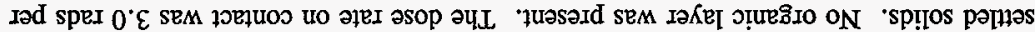

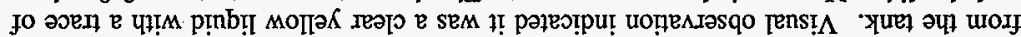

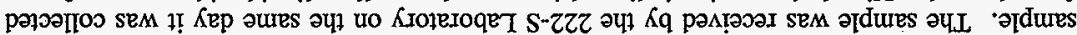

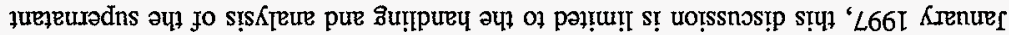


101-AP-2 and 101-AP-3. Dose rates on contact were 25 and 40 millirads per hour, respectively. A full recovery of $125 \mathrm{~mL}$ was obtained for both grab samples. No other information regarding the sampling event was available.

The samples were received by the 222-S Laboratory on March 30, 1995. The required analytes included $\mathrm{pH}$, chloride, fluoride, hydroxide, nitrate, nitrite, phosphate, sulfate, and TIC. Section B2.3.1 shows the results from the sampling event. Because tank 241-AP-101 has been active, that is, wastes have been received and transferred since the sampling event, the results no longer represent current tank contents.

\section{B1.3.2 December 1994 Grab Sampling}

The December 1994 grab samples were also taken to determine whether tank 241-AP-101 was within tank corrosion control specifications. Again, no tank characterization plan was required because sampling was done for process control reasons. The sampling was directed by "Letter of Instruction for Tank 241-AP-101 Grab Samples" (Bratzel 1994).

Information regarding the sampling event was limited. Two grab samples were obtained, and were assigned numbers 101-AP-1 and 101-AP-2 (Bratzel (1994). Sample depths and sample risers were not available. The samples were received by the 222-S Laboratory on December 16, 1994. Before analysis, the samples were assigned laboratory identification numbers $\mathrm{R} 6833$ and $\mathrm{R} 6834$. The required analytes included $\mathrm{pH}$, chloride, fluoride, hydroxide, nitrate, nitrite, phosphate, sulfate, and TIC. Results for these analytes were reported in Rollison (1995b) and are shown in Section B2.3.2. These results should be used with caution because they no longer represent current tank contents.

\section{B1.3.3 July 1993 Grab Sampling}

Tank 241-AP-101 was sampled in 1993 to evaluate the fitness of the tank waste to be processed in the 242-A Evaporator. Analytical results from these samples were previously reported in the 222-S Validation Summary for Double-Shell Tank 241-AP-101 (Miller 1993) and Revision 0 of this TCR. Given the active waste transfer history of the tank, analytical results from these samples do not represent the current contents of the tank.

On July 20, 1993, supernatant samples were collected in duplicate from risers 1 at $90^{\circ}$ (E), 2 at $210^{\circ}(\mathrm{SW})$, and 3 at $330^{\circ}$ (NW) at five locations within the waste using the bottle-on-a-string method. An additional sample was collected (from riser 1 at $210^{\circ}$ ) from the waste surface level for a TOC analysis. Each sample bottle collected approximately $100 \mathrm{~mL}$ of liquid. One complete set of samples was delivered to the Pacific Northwest Laboratory for organic analyses; the remaining set was delivered to the 222-S Laboratory where it underwent inorganic and physical property analyses. A composite sample was prepared from equal portions of the five samples for radiological analyses at the 
222-S Laboratory. All samples were described as being similar in appearance: colorless and clear liquids containing no visible solids. Section B2.3.3 shows the analytical results.

\section{B2.0 ANALYTICAL RESULTS}

This section summarizes the sampling and analytical results associated with the November 1995 sampling and analysis of tank 241-AP-101. Table B2-1 shows the total alpha activity, radionuclide, percent water, energetics, specific gravity, $\mathrm{pH}, \mathrm{IC}$, and ICP analytical results associated with this tank. The results are documented in Esch (1996).

This section also summarizes the sampling and analytical results associated with the July 1995 sampling of 242-A Evaporator slurry and the August 1995 sampling of tank 241-AW-106. These results are documented in Guthrie (1996) and Esch (1995b). These sampling events provide data for supernatant which was transferred from tank 241-AW-106 to tank 241-AP-101 in March 1996 and January 1997.

Table B2-1. Analytical Presentation Tables.

\begin{tabular}{|c|c|}
\hline 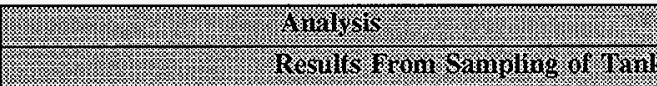 & 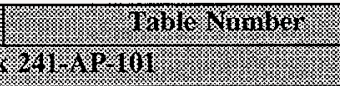 \\
\hline Metals by ICP & B2-2 through B2-4 \\
\hline Anions by IC and hydroxide by potentiometric titration & B2-5 through B2-11 \\
\hline Total inorganic and organic carbon & $\mathrm{B} 2-12$ and $\mathrm{B} 2-13$ \\
\hline Radionuclides & B2-14 through B2-19 \\
\hline Weight percent water & $\mathrm{B} 2-20$ \\
\hline Differential scanning calorimetry & B2-21 \\
\hline Specific gravity & $B 2-22$ \\
\hline $\mathrm{pH}$ & $\mathrm{B} 2-23$ \\
\hline Vapor phase measurements & $\mathrm{B} 2-24$ \\
\hline 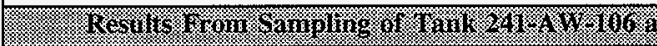 & 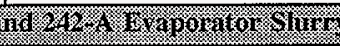 \\
\hline Chemical data & $\mathrm{B} 2-25$ \\
\hline Weight percent water & $B 2-26$ \\
\hline Differential scanning calorimetry & B2-27 \\
\hline 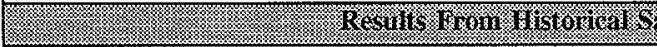 & ampling \\
\hline Results from March 1995 grab sampling & B2-28 \\
\hline Results from December 1994 grab sampling & B2-29 \\
\hline Results from July 1993 grab sampling & $\mathrm{B} 2-30$ \\
\hline
\end{tabular}




\section{B2.1 RESULTS FROM 1995 GRAB SAMPLING OF TANK 241-AP-101}

The four QC parameters assessed in conjunction with tank 241-AP-101 samples were standard recoveries, spike recoveries, duplicate analyses (relative percent differences [RPDs]), and blanks. The QC criteria specified in the sampling and analysis plan (SAP) (Esch 1995b) were 90 to 110 percent for standards and spikes and $\leq 10$ percent for RPDs for DSC and TGA. For all other analytes, the QC criteria were 80 to 120 percent for standards and spikes and $\leq 20$ percent for RPDs. The only QC parameter for which limits are not specified in the SAP is blank contamination. The limits for blanks are in laboratory guidelines, and all data results in this report have met those guidelines. Sample and duplicate pairs, in which any of the QC parameters were outside of these limits, are footnoted in the sample mean column of the data summary tables with an $a, b, c$, d, or e as follows:

- $\quad$ "a" indicates the standard recovery was below the QC limit.

- $\quad$ " $b "$ indicates the standard recovery was above the QC limit.

- $\quad$ " $c$ " indicates the spike recovery was below the QC limit.

- $\quad \mathrm{d}$ " indicates the spike recovery was above the QC limit.

- $\quad$ "e" indicates the RPD was above the QC limit.

In each data table, the "Mean" column is the average of result and duplicate values. All values, including those below the detection level (designated by $<$ ), were averaged. If result and duplicate values were detected, the mean is expressed as a detected value. If both values were nondetected, or if one value was detected and the other nondetected, the mean is expressed as a nondetected value.

Samples 1AP-95-1 and 1AP-95-2 have been switched from their normal order in the data tables. This was done to maintain depth consistency because sample 1AP-95-1 was actually taken from a lower depth than sample 1AP-95-2.

\section{B2.1.1 Inorganic Analyses}

B2.1.1.1 Inductively Coupled Plasma. The ICP analyses were performed according to procedure LA-505-161, Rev. B-0. Only aluminum, iron, and sodium results were reported. The ICP results are shown in Tables B2-2 through B2-4.

Table B2-2. Tank 241-AP-101 Analytical Results: Aluminum. (2 sheets)

\begin{tabular}{|c|c|c|c|c|c|}
\hline Surno & diser: & $\begin{array}{l}\text { Orab } \\
\text { Samink }\end{array}$ & ressill & Bupluterte & Mern \\
\hline Guperanano & স & & 6.96\% & $.0 \mathrm{gmi}$ & 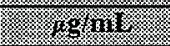 \\
\hline S95T003722 & \multirow[t]{2}{*}{1 at $210^{\circ}$} & $1 \mathrm{AP}-95-2$ & 10,700 & 11,400 & 11,000 \\
\hline S95T003721 & & 1AP-95-1 & 11,500 & 11,600 & 11,600 \\
\hline
\end{tabular}




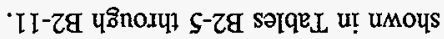

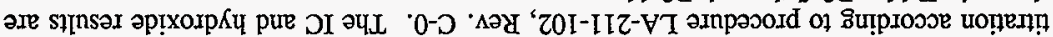

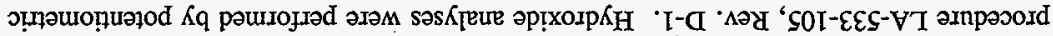

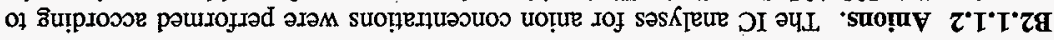

\begin{tabular}{|c|c|c|c|c|c|}
\hline $\mathrm{S}_{0}+\mathrm{B} \downarrow L^{\circ} \mathrm{I}$ & $\mathrm{SO}+\mathrm{B} \angle L^{\prime} \mathrm{I}$ & $S_{0}+\mathrm{E} L L^{\prime} \mathrm{I}$ & $9-\varsigma 6-d V I$ & \multirow[b]{3}{*}{.OEE TE I } & OELEOOLSGS \\
\hline $\mathrm{SO}+\mathrm{G} \angle L^{\circ} \mathrm{I}$ & $\mathrm{S} 0+\mathrm{B} \angle 8^{\circ} \mathrm{I}$ & $S 0+B \angle 9^{\circ} \mathrm{I}$ & $s-s 6-d \forall I$ & & $6 Z L E 00 \mathrm{LS} 6 \mathrm{~S}$ \\
\hline $\mathrm{S}_{0}+\mathrm{A} 8 \mathrm{~S}^{\prime} \mathrm{I}$ & $\mathrm{S}_{0}+\mathrm{B} \angle \mathrm{S}^{\prime} \mathrm{I}$ & $\mathrm{S}_{0}+\exists 8 \mathrm{~S}^{\circ} \mathrm{I}$ & $t-\varsigma 6-d \forall I$ & & $8 Z L E 00 \mathrm{LS} 6 \mathrm{~S}$ \\
\hline $\mathrm{S}_{0}+\mathrm{Z} Z L^{\circ} \mathrm{I}$ & $\mathrm{S}_{0}+\mathrm{B} L L^{\prime} I$ & $S_{0}+\mathrm{BZ} L^{\prime} I$ & $\varepsilon-\mathrm{S} 6-\mathrm{d} \forall I$ & \multirow[b]{3}{*}{$.01 Z 1 E \mathrm{I}$} & $\varepsilon Z \angle \varepsilon 00 L S 6 \mathrm{~S}$ \\
\hline $\mathrm{S}_{0}+\mathrm{B} 6 \mathrm{~S}^{\circ} \mathrm{I}$ & S0+309' I & $\mathrm{S} 0+\mathrm{B} 8 \mathrm{~S}^{\circ} \mathrm{I}$ & $I-s 6-d \forall I$ & & IZLE00IS6S \\
\hline $\mathrm{SO}_{0}+\mathrm{GES}^{\circ} \mathrm{I}$ & $\mathrm{S}_{0}+\mathrm{B} 8 \mathrm{~S}^{\prime} \mathrm{I}$ & $50+Z 8 \nabla^{\circ} I$ & $z-\$ 6-d \forall I$ & & $\tau Z \angle E 00 L S 6 \mathrm{~S}$ \\
\hline I) & Thior & $1478 \%$ & (3) & (2) & 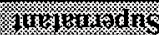 \\
\hline and & 3y & Iysis & 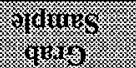 & 40 & 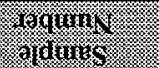 \\
\hline
\end{tabular}

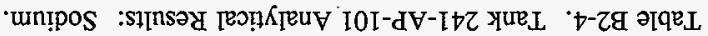

\begin{tabular}{|c|c|c|c|c|c|}
\hline $0.0 z>$ & $0.02>$ & $0.0 z>$ & $9-S_{6}-\mathrm{dVI}$ & \multirow[b]{3}{*}{.0EE I I I } & $0 \varepsilon \angle \varepsilon 00 \perp \subseteq 6 \mathrm{~S}$ \\
\hline $0.0 z>$ & $0.02>$ & $0.0 z>$ & $\varsigma-\varsigma 6-d V I$ & & 6ZLE00LS6S \\
\hline $0.0 z>$ & $0.0 \tau>$ & $0.0 z>$ & $t-56-\mathrm{dVI}$ & & 8ZLE00LS6S \\
\hline $0.02>$ & $0.02>$ & $0.0 z>$ & $\varepsilon-S 6-\mathrm{dVI}$ & \multirow[b]{3}{*}{$.0 I z)$ I } & $\varepsilon Z L E 00 L S 6 S$ \\
\hline $0.0 z>$ & $0.0 z>$ & $0.0 z>$ & $\mathrm{I}-\mathrm{SG}_{6} \mathrm{dVI}$ & & IZLEO0IS6S \\
\hline $0.0 z>$ & $0.0 z>$ & $0.0 z>$ & $\tau-\varsigma 6-d \forall I$ & & ZZLE00LS6S \\
\hline 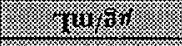 & warn & 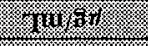 & & & M \\
\hline (3) & anding & minsory & 9 frings & 10038 & rorgury \\
\hline
\end{tabular}

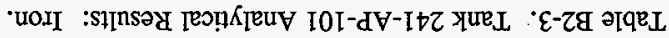

\begin{tabular}{|c|c|c|c|c|c|}
\hline $00 L^{\prime} \mathrm{ZI}$ & $006^{6} \mathrm{ZI}$ & $00 S^{\prime} Z I$ & $9-\varsigma_{6}-\mathrm{dVI}$ & \multirow[b]{3}{*}{ ○OEE TR I } & $0 \varepsilon \angle \varepsilon 00 \perp S 6 \mathrm{~S}$ \\
\hline $00 \varepsilon^{\prime} \varepsilon I$ & $00 I^{6}+I$ & $00 S^{\prime} \mathrm{ZI}$ & $\varsigma-\varsigma 6-d V I$ & & $6 Z L \varepsilon 00 L S 6 S$ \\
\hline $00 S^{\prime} I I$ & $00 t^{6} \mathrm{II}$ & $00 S^{\prime} I I$ & $t-\varsigma 6-\mathrm{dVI}$ & & $8 Z \angle E 00 L S 6 S$ \\
\hline $009^{\prime} \mathrm{ZI}$ & $009^{\prime} \mathrm{ZI}$ & $00 L^{\prime} Z I$ & $\varepsilon-\varsigma 6-d V I$ & .0Tz 78 I & $\varepsilon Z L E 00 I S 6 S$ \\
\hline ngar & anemglim & misory & 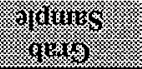 & . 0981 & 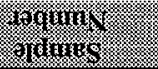 \\
\hline
\end{tabular}

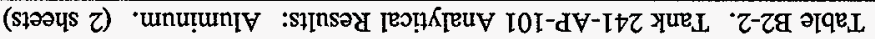




\begin{tabular}{|c|c|c|c|c|c|}
\hline $00 \mathcal{E}^{6} 0 \mathrm{~s}$ & $006^{\circ} 87$ & $00 L^{6} I S$ & $9-56-d V I$ & \multirow[b]{3}{*}{.0EE $¥ \mathrm{E} I$} & OELEO0LS6S \\
\hline $00 I^{6} 0 s$ & $00 \varepsilon^{\prime} 0 S$ & $006^{6} 6 t$ & $s-s 6-d \forall I$ & & 6ZLE00LS6S \\
\hline $00 \angle ' 0 S$ & $000^{\prime} 0 \mathrm{~s}$ & $00 t^{6} \mathrm{IS}$ & $7-56-d V I$ & & 8ZLE00IS6S \\
\hline $006^{\circ} \mathrm{ES}$ & $00 I^{6} \neq S$ & $00 L^{\circ} \varepsilon S$ & $\varepsilon-\varsigma 6-d V I$ & \multirow[b]{3}{*}{$.0 I Z \mathfrak{I E} I$} & EZLE00LS6S \\
\hline $00 z^{6} 6 t$ & $006^{\circ} \angle t$ & $009^{\circ} 0 \$$ & $I-\varsigma 6-d \forall I$ & & IZLEO0LS6S \\
\hline $00 z^{\prime} z t$ & $008^{\prime} z t$ & $00 L^{6} I t$ & $z-\$ 6-d \forall I$ & & ZZLE00IS6S \\
\hline H. & 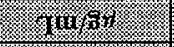 & (1) & & & 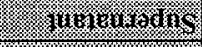 \\
\hline (1) & \%), & 19.6. & 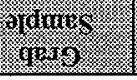 & 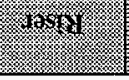 & magring \\
\hline
\end{tabular}

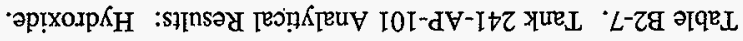

\begin{tabular}{|c|c|c|c|c|c|}
\hline$: 005 I^{6} \mathrm{I}$ & OIE'I $\mathrm{I}$ & 0.786 & $9-\mathrm{s} 6-\mathrm{dVI}$ & \multirow[b]{3}{*}{$.0 E E$ ie I } & $0 \varepsilon \angle E 00 L S 6 \mathrm{~S}$ \\
\hline $0 \tau \varepsilon^{\prime} I$ & $0 z \varepsilon^{6} \mathfrak{I}$ & $0 z \varepsilon^{\prime} \mathrm{I}$ & s-s6-dVI & & 6ZLE00LS6S \\
\hline $0 z 8^{\prime} z$ & $0 \varepsilon 8^{6} z$ & $0 z 8^{\prime} z$ & $t-56-d V I$ & & 8ZLE00IS6S \\
\hline $0 S 0^{\prime} \mathrm{Z}$ & $0 \varepsilon 0^{\circ} \mathrm{Z}$ & $0 \angle 0^{\circ} \mathrm{Z}$ & $\varepsilon-\varsigma 6-d V I$ & \multirow[b]{3}{*}{$.0 I Z \mathfrak{T} I$} & $\varepsilon Z L E 00 L S 6 S$ \\
\hline $0 \operatorname{sit} z$ & $0 t t^{6} \mathrm{z}$ & $0 \sin ^{6} \tau$ & $\mathrm{I}-\mathrm{S}^{-\mathrm{dVI}}$ & & IZLEO0LS6S \\
\hline $00 L^{\prime} z$ & $0 I L^{\prime} Z$ & $069^{\circ} z$ & $\tau-S 6-\mathrm{dVI}$ & & ZZLE00.LS6S \\
\hline 31060 & (18. & 19076ris & & & 14tiveraradns \\
\hline 10u & - & 1MSTU: & $\begin{array}{l}\text { rofuds } \\
\text { 91845 }\end{array}$ & . & 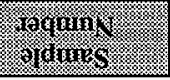 \\
\hline
\end{tabular}

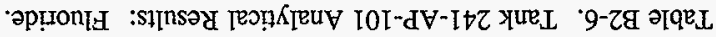

\begin{tabular}{|c|c|c|c|c|c|}
\hline $0 z 0^{\circ} z$ & $0 \varepsilon 6^{6} \mathrm{I}$ & $0 I I^{\prime} z$ & 9-ৎ6-dVI & \multirow[b]{3}{*}{.OEE TE I } & OELEO0LSGS \\
\hline $010^{6} z$ & $010^{6} z$ & $010^{6} z$ & $s-\varsigma 6-d V I$ & & $6 Z L E 00 L S 6 \mathrm{~S}$ \\
\hline $0 z I^{\prime} z$ & $0 Z I^{\prime} Z$ & OZI'Z & $\nabla-\varsigma 6-\mathrm{d} \forall I$ & & 8ZLE00LS6S \\
\hline $0+I^{6} z$ & $0 \varepsilon I^{\prime} z$ & OSI' $\mathrm{Z}$ & $\varepsilon-\varsigma 6-d V I$ & \multirow[b]{3}{*}{$.0[2$ 1 } & EZLE00LS6S \\
\hline $086^{6} \mathrm{I}$ & $0 L 6^{6} \mathrm{~T}$ & $000^{\prime} z$ & $\mathrm{I}-\mathrm{s} 6-\mathrm{dVI}$ & & $I Z \angle E 00$ IS6S \\
\hline $016^{\circ} \mathrm{I}$ & $006^{\circ} \mathrm{T}$ & $0 \varepsilon 6^{\prime} \mathrm{I}$ & $\tau-\varsigma 6-d \forall I$ & & $Z Z \angle E 00 I S 6 S$ \\
\hline gingist & (1) & IIn & & & Hunguradins \\
\hline 1Eง 1 & - 1004 ding & & ofuras & & 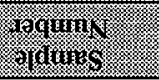 \\
\hline
\end{tabular}

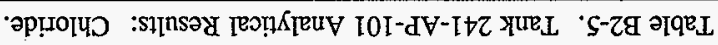


Table B2-8. Tank 241-AP-101 Analytical Results: Nitrate.

\begin{tabular}{|c|c|c|c|c|c|}
\hline S.mpice & Riser & Givilo & 1 resiu & 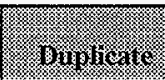 & 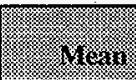 \\
\hline Superintani & (3) & & 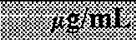 & $(8)$ & 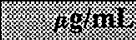 \\
\hline S95T003722 & \multirow[t]{3}{*}{1 at $210^{\circ}$} & $1 \mathrm{AP}-95-2$ & $1.47 \mathrm{E}+05$ & $1.47 \mathrm{E}+05$ & $1.47 \mathrm{E}+05$ \\
\hline S95T003721 & & $1 \mathrm{AP}-95-1$ & $1.50 \mathrm{E}+05$ & $1.51 \mathrm{E}+05$ & $1.50 \mathrm{E}+05$ \\
\hline S95T003723 & & $1 \mathrm{AP}-95-3$ & $1.82 \mathrm{E}+05$ & $1.80 \mathrm{E}+05$ & $1.81 \mathrm{E}+05$ \\
\hline S95T003728 & \multirow[t]{3}{*}{1 at $330^{\circ}$} & $1 \mathrm{AP}-95-4$ & $1.56 \mathrm{E}+05$ & $1.56 \mathrm{E}+05$ & $1.56 \mathrm{E}+05$ \\
\hline S95T003729 & & 1 AP-95-5 & $1.48 \mathrm{E}+05$ & $1.45 \mathrm{E}+05$ & $1.46 \mathrm{E}+05$ \\
\hline S95T003730 & & $1 \mathrm{AP}-95-6$ & $1.46 \mathrm{E}+05$ & $1.41 \mathrm{E}+05$ & $1.44 \mathrm{E}+05$ \\
\hline
\end{tabular}

Table B2-9. Tank 241-AP-101 Analytical Results: Nitrite.

\begin{tabular}{|c|c|c|c|c|c|}
\hline Sainple & inger & $\begin{array}{l}\text { Giris } \\
\text { Shimple }\end{array}$ & resinge & burbicinge & merro \\
\hline Supernatan & 8.8 & s: & 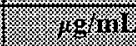 & 1,4 on & (1) \\
\hline S95T003722 & \multirow[t]{3}{*}{1 at $210^{\circ}$} & 1AP-95-2 & 38,700 & 38,600 & 38,700 \\
\hline S95T003721 & & 1AP-95-1 & 40,900 & 40,000 & 40,500 \\
\hline S95T003723 & & 1AP-95-3 & 47,100 & 46,500 & 46,800 \\
\hline S95T003728 & \multirow[t]{3}{*}{1 at $330^{\circ}$} & $1 \mathrm{AP}-95-4$ & 41,800 & 42,300 & 42,000 \\
\hline S95T003729 & & $1 \mathrm{AP}-95-5$ & 41,700 & 41,900 & 41,800 \\
\hline S95T003730 & & 1AP-95-6 & 41,200 & 40,000 & 40,600 \\
\hline
\end{tabular}

Table B2-10. Tank 241-AP-101 Analytical Results: Phosphate.

\begin{tabular}{|c|c|c|c|c|c|}
\hline $\begin{array}{l}\text { Sample } \\
\text { Niminer }\end{array}$ & (tosel: & $\begin{array}{l}\text { Grab } \\
\text { sampio }\end{array}$ & (1esili: & buplicate & morin \\
\hline Supermatint: & & & (1) & 14.1951110 & (4971 \\
\hline S95T003722 & \multirow[t]{3}{*}{1 at $210^{\circ}$} & $1 \mathrm{AP}-95-2$ & $<1,210$ & $<1,210$ & $<1,210$ \\
\hline S95T003721 & & 1AP-95-1 & $<1,214$ & $<1,210$ & $<1,212$ \\
\hline S95T003723 & & $1 \mathrm{AP}-95-3$ & $<613$ & $<613$ & $<613$ \\
\hline S95T003728 & \multirow[t]{3}{*}{1 at $330^{\circ}$} & 1AP-95-4 & 998.9 & 1,030 & 1,010 \\
\hline S95T003729 & & $1 \mathrm{AP}-95-5$ & 614.0 & 619.0 & 616.5 \\
\hline S95T003730 & & $1 \mathrm{AP}-95-6$ & 745.7 & 828.0 & 786.9 \\
\hline
\end{tabular}


Table B2-11. Tank 241-AP-101 Analytical Results: Sulfate.

\begin{tabular}{|c|c|c|c|c|c|}
\hline Samule. & Riser: & $\begin{array}{l}\text { Grab } \\
\text { simiphe }\end{array}$ & SIsesian & Buritaris & 16an \\
\hline Supernatant & 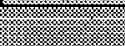 & (1) & (19. nin & 6ring & (4) Gin \\
\hline S95T003722 & \multirow[t]{3}{*}{1 at $210^{\circ}$} & $1 \mathrm{AP}-95-2$ & 3,510 & 3,530 & 3,520 \\
\hline S95T003721 & & 1AP-95-1 & 3,220 & 3,220 & 3,220 \\
\hline S95T003723 & & $1 \mathrm{AP}-95-3$ & 2,110 & 2,170 & 2,140 \\
\hline S95T003728 & \multirow[t]{3}{*}{1 at $330^{\circ}$} & $1 \mathrm{AP}-95-4$ & 2,930 & 2,940 & 2,940 \\
\hline S95T003729 & & $1 \mathrm{AP}-95-5$ & 2,120 & 2,130 & 2,120 \\
\hline S95T003730 & & $1 \mathrm{AP}-95-6$ & 1,780 & 1,710 & 1,740 \\
\hline
\end{tabular}

\section{B2.1.2 Total Inorganic Carbon and Total Organic Carbon}

The TIC analyses were performed by furnace oxidation according to procedure LA-622-102, Rev. C- 0 . The TOC analyses were performed by furnace oxidation according to procedure LA-344-105, Rev. C-0. The results of these analyses are shown in Tables B2-12 and B2-13.

Table B2-12. Tank 241-AP-101 Analytical Results: Total Inorganic Carbon.

\begin{tabular}{|c|c|c|c|c|c|}
\hline $\begin{array}{l}\text { Sample } \\
\text { Simucr }\end{array}$ & .1856 & Sampic & Iresiril: & 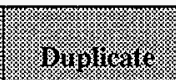 & 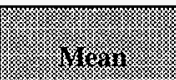 \\
\hline Silworvatinit: & י: & 8 & (3) & (3) & 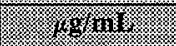 \\
\hline S95T003722 & \multirow[t]{3}{*}{1 at $210^{\circ}$} & 1AP-95-2 & 5,290 & 5,440 & 5,360 \\
\hline S95T003721 & & $1 \mathrm{AP}-95-1$ & 4,970 & 4,940 & 4,960 \\
\hline S95T003723 & & $1 \mathrm{AP}-95-3$ & 4,280 & 4,310 & 4,300 \\
\hline$\overline{\text { S95T003728 }}$ & \multirow[t]{3}{*}{1 at $330^{\circ}$} & $1 \mathrm{AP}-95-4$ & 5,040 & 5,100 & 5,070 \\
\hline S95T003729 & & 1AP-95-5 & 3,780 & 3,740 & 3,760 \\
\hline S95T003730 & & 1AP-95-6 & 3,810 & 3,820 & 3,820 \\
\hline
\end{tabular}


Table B2-13. Tank 241-AP-101 Analytical Results: Total Organic Carbon.

\begin{tabular}{|c|c|c|c|c|c|}
\hline 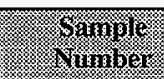 & 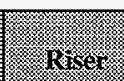 & 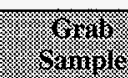 & 1645ill & B Bry 13 care & \% \\
\hline Sho wng daro & & & rging & $18 \%$ / 1391 & 湆 \\
\hline \$95T003722 & \multirow[t]{3}{*}{1 at $210^{\circ}$} & $1 \mathrm{AP}-95-2$ & 2,100 & 2,100 & 2,100 \\
\hline \$95T003721 & & $1 \mathrm{AP}-95-1$ & 2,040 & 2,070 & 2,060 \\
\hline S95T003723 & & $1 \mathrm{AP}-95-3$ & 2,260 & 2,430 & 2,340 \\
\hline S95T003728 & \multirow[t]{3}{*}{1 at $330^{\circ}$} & $1 \mathrm{AP}-95-4$ & 3,160 & 3,570 & 3,360 \\
\hline \$95T003729 & & $1 \mathrm{AP}-95-5$ & 3,210 & 3,260 & 3,240 \\
\hline S95T003730 & & 1 AP-95-6 & 3,070 & 2,940 & 3,000 \\
\hline
\end{tabular}

\section{B2.1.3 Radionuclides}

Analyses for total alpha activity and various radionuclides were performed on samples recovered from tank 241-AP-101. Alpha proportional counting was performed to determine the activities of total alpha (procedure LA-508-101, Rev. D-2), ${ }^{241}$ Am (procedure LA-953-103, Rev. A-4), and ${ }^{239 / 240} \mathrm{Pu}$ (procedure LA-943-127, Rev. B-1). Gamma energy analysis was used to measure the ${ }^{137} \mathrm{Cs}$ and ${ }^{60} \mathrm{Co}$ activities according to procedure LA-548-121, Rev. D-1. Procedure LA-220-101, Rev. D-1, was used for determining the ${ }^{90} \mathrm{Sr}$ activity by beta proportional counting. The sample results for the radionuclides are given in Tables B2-14 through B2-19.

Table B2-14. Tank 241-AP-101 Analytical Results: Total Alpha Activity.

\begin{tabular}{|c|c|c|c|c|c|}
\hline Siming & Haser & 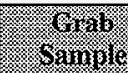 & Kesuil & 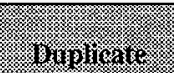 & 140 \\
\hline 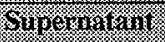 & & & w) & (1) & (n) \\
\hline S95T003732 & \multirow[t]{3}{*}{1 at $210^{\circ}$} & $1 \mathrm{AP}-95-2$ & $<0.00311$ & $<0.00251$ & $<0.00281$ \\
\hline S95T003731 & & $1 \mathrm{AP}-95-1$ & $<0.00159$ & $<0.00341$ & $<0.00250$ \\
\hline S95T003733 & & $1 \mathrm{AP}-95-3$ & $<0.00341$ & $<0.00189$ & $<0.00265$ \\
\hline S95T003735 & \multirow[t]{3}{*}{1 at $330^{\circ}$} & $1 \mathrm{AP}-95-4$ & $<0.00256$ & $<0.00256$ & $<0.00256$ \\
\hline S95T003736 & & $1 \mathrm{AP}-95-5$ & $<0.00225$ & $<0.00256$ & $<0.00241$ \\
\hline S95T003737 & & $1 \mathrm{AP}-95-6$ & $<0.00287$ & $<0.00287$ & $<0.00287$ \\
\hline
\end{tabular}




\begin{tabular}{|c|c|c|c|c|c|}
\hline $21 \varepsilon 0^{\circ} 0>$ & $90 \varepsilon 0^{\circ} 0>$ & $8 I \varepsilon 0^{\circ} 0>$ & 9-S6-dVI & \multirow[b]{3}{*}{$.0 \mathcal{E}\rceil \mathbb{E}$ I } & $\angle E L E 00 L S 6 S$ \\
\hline$\varepsilon S Z 0^{\circ} 0>$ & $\varepsilon \angle Z 0^{\circ} 0>$ & $Z \mathcal{E Z 0 ^ { \circ } 0 >}$ & $\varsigma-\varsigma 6-d \forall I$ & & 9ELE00LS6S \\
\hline$t 9 \varepsilon 0^{\circ} 0>$ & $\downarrow \subseteq E 0^{\circ} 0>$ & $\varepsilon \angle E 0^{\circ} 0>$ & $\mathrm{v}-\mathrm{S} 6-\mathrm{d} \forall \mathrm{I}$ & & SELE00LS6S \\
\hline $00+0^{\circ} 0>$ & $\varepsilon \nabla 70^{\circ} 0>$ & $\angle S E O^{\circ} O>$ & $\mathcal{E}-\varsigma 6-d V I$ & \multirow[b]{3}{*}{$.0127 \mathbb{R} I$} & $\mathcal{E E L E O 0 L S 6 S}$ \\
\hline$S \angle E 0^{\circ} 0>$ & $8 \angle E 0^{\circ} 0>$ & $Z \angle E 0^{\circ} 0>$ & I-S6-dVI & & IELE00LS6S \\
\hline$S \angle E 0^{\circ} 0>$ & $Z \angle E 0^{\circ} 0>$ & $8 \angle E 0^{\circ} 0>$ & $\tau-\varsigma 6-d \forall I$ & & $\tau \mathcal{L} L E 00 L S 6 \mathrm{~S}$ \\
\hline (3) & 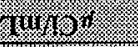 & 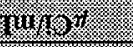 & & & 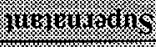 \\
\hline atson. & 1084619 & 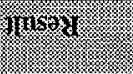 & rigus & 6 & 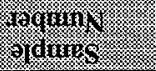 \\
\hline
\end{tabular}

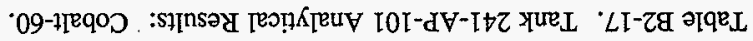

\begin{tabular}{|c|c|c|c|c|c|}
\hline$S \angle 6 \mathrm{I}$ & $0^{\circ} 002$ & $0.56 \mathrm{I}$ & 9-S6-dVI & \multirow[b]{3}{*}{.0EE $\mathfrak{T}$ I } & $\angle E L E 00 L S 6 \mathrm{~S}$ \\
\hline sitz & $0^{\circ}$ IIZ & $0 . \mathrm{zIz}$ & s-ৎ6-dVI & & $9 \varepsilon \angle \varepsilon 00 L S 6 S$ \\
\hline $0.0 \angle \mathrm{L}$ & $0^{\circ} Z \angle I$ & 0.891 & $t-\varsigma 6-d V I$ & & SELEO0LS6S \\
\hline $0.96 \mathrm{I}$ & $0^{\circ} \mathrm{S} 6 \mathrm{I}$ & $0.26 \mathrm{I}$ & $\varepsilon-\varsigma 6-\mathrm{d} V I$ & \multirow[b]{3}{*}{.012 IR I } & $\varepsilon \varepsilon \angle \varepsilon 00 \mathrm{LS} 6 \mathrm{~S}$ \\
\hline S.I8I & $0.28 \mathrm{I}$ & 0.181 & I-S6-dVI & & IELEO0LS6S \\
\hline $0^{\circ} \varepsilon L I$ & $0^{\circ} 9 \mathrm{LI}$ & $0.0 \angle I$ & $z-S 6-d V I$ & & $\tau \varepsilon L E 00 \mathrm{~L} S 6 \mathrm{~S}$ \\
\hline $1 m_{12}$ & mingris & 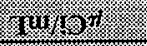 & S: & & 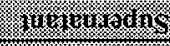 \\
\hline 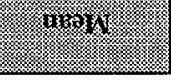 & 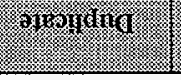 & musวu & 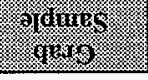 & 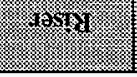 & $\begin{array}{l}\text { jogumy } \\
\text { ofluns }\end{array}$ \\
\hline
\end{tabular}

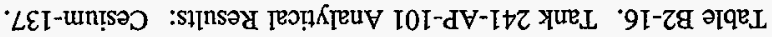

\begin{tabular}{|c|c|c|c|c|c|}
\hline $50-3 s s^{\circ} \varepsilon>$ & $\neg 0-\exists \mapsto 66^{\circ} \varepsilon>$ & 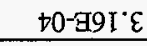 & $9-\subseteq 6-d V I$ & \multirow[b]{3}{*}{$.0 E E I E I$} & $\angle \varepsilon L E 00 . L S 6 \mathrm{~S}$ \\
\hline t0-G6I $\varepsilon>$ & $t 0-\not 8 \varepsilon^{\circ} \varepsilon>$ & $t 0-\exists 00^{\circ} \varepsilon$ & $s-\varsigma 6-d \forall I$ & & $9 \varepsilon L E 00 L S 6 S$ \\
\hline$\neq 0-\mathrm{G} I L \cdot \varepsilon>$ & $t 0-\pi s 9^{\circ} \varepsilon>$ & $+0-\mathrm{B} L L \cdot \varepsilon>$ & $t-S_{6}-\mathrm{d} \forall I$ & & SELE00LS6S \\
\hline$t 0^{-} \mathrm{B}+0^{\circ} \varepsilon$ & $70^{-}-\underline{B} S 0^{\circ} \varepsilon$ & $+00^{-} \mathrm{B} z 0^{\circ} \mathcal{\varepsilon}$ & $\varepsilon-\varsigma 6-d V I$ & \multirow[b]{3}{*}{.0012 te $\mathrm{I}$} & $\varepsilon \varepsilon \angle \varepsilon 00 L S 6 \mathrm{~S}$ \\
\hline$+0-900^{\circ} \varepsilon$ & $\neq 0-\theta+0^{\circ} \varepsilon$ & $+0-9 \subseteq 6^{\circ} \tau$ & I- $\subseteq 6-\mathrm{dVI}$ & & IELEOOLS6S \\
\hline to- $886^{\circ} \mathrm{z}$ & $10^{-}-\exists<6^{\circ} \mathrm{Z}$ & to- $-\mathrm{B} 00^{\circ} \mathcal{E}$ & $\tau-\varsigma 6-d V I$ & & ZELE00LS6S \\
\hline $7_{14}$ & (15is) & 1uly & (3) & & inguritodis \\
\hline X) & 4ex) & 111528 & ग) & & 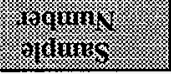 \\
\hline
\end{tabular}

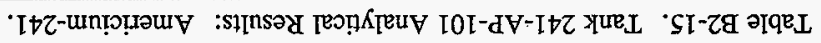


Table B2-18. Tank 241-AP-101 Analytical Results: Plutonium-239/240.

\begin{tabular}{|c|c|c|c|c|c|}
\hline $\begin{array}{l}\text { Sample } \\
\text { Niminger }\end{array}$ & miser & Granglo & Resulit & (3) & 118.10 \\
\hline Sypermaran: & & $\sqrt{3}$ & 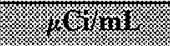 & 11010101 & 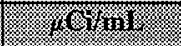 \\
\hline S95T003732 & \multirow[t]{3}{*}{1 at $210^{\circ}$} & 1AP-95-2 & $1.64 \mathrm{E}-04$ & $1.67 \mathrm{E}-04$ & $1.66 \mathrm{E}-04$ \\
\hline S95T003731 & & 1AP-95-1 & $1.56 \mathrm{E}-04$ & $1.55 \mathrm{E}-04$ & $1.55 \mathrm{E}-04$ \\
\hline \$95T003733 & & $1 \mathrm{AP}-95-3$ & $1.59 \mathrm{E}-04$ & $1.45 \mathrm{E}-04$ & $1.52 \mathrm{E}-04$ \\
\hline S95T003735 & \multirow[t]{3}{*}{1 at $330^{\circ}$} & $1 \mathrm{AP}-95-4$ & $1.46 \mathrm{E}-04$ & $1.58 \mathrm{E}-04$ & $1.52 \mathrm{E}-04$ \\
\hline S95T003736 & & $1 \mathrm{AP}-95-5$ & $1.61 \mathrm{E}-04$ & $1.86 \mathrm{E}-04$ & $1.73 \mathrm{E}-04$ \\
\hline S95T003737. & & $1 \mathrm{AP}-95-6$ & $1.79 \mathrm{E}-04$ & $1.87 \mathrm{E}-04$ & $1.83 \mathrm{E}-04$ \\
\hline
\end{tabular}

Table B2-19. Tank 241-AP-101 Analytical Results: Strontium-89/90.

\begin{tabular}{|c|c|c|c|c|c|}
\hline Sample & 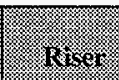 & Singl. & Resinl: & Bumincites & yiturn. \\
\hline Super ruatan & $\sqrt{3}$ & $\sqrt{\prime}$ & (3) & WT YIII & 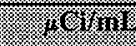 \\
\hline S95T003732 & \multirow[t]{3}{*}{1 at $210^{\circ}$} & $1 \mathrm{AP}-95-2$ & 0.159 & 0.146 & 0.152 \\
\hline S95T003731 & & $1 \mathrm{AP}-95-1$ & 0.133 & 0.135 & 0.134 \\
\hline S95T003733 & & $1 \mathrm{AP}-95-3$ & 0.163 & 0.163 & 0.163 \\
\hline S95T003735 & \multirow[t]{3}{*}{1 at $330^{\circ}$} & $1 \mathrm{AP}-95-4$ & 0.179 & 0.189 & 0.184 \\
\hline S95T003736 & & $1 \mathrm{AP}-95-5$ & 0.195 & 0.184 & 0.190 \\
\hline S95T003737 & & 1AP-95-6 & 0.107 & 0.111 & 0.109 \\
\hline
\end{tabular}

\section{B2.1.4 Physical Properties Analyses}

As required by the safety screening and waste compatibility DQOs, TGA, DSC, specific gravity, and $\mathrm{pH}$ analyses were performed on the samples. No other physical tests were required or performed.

B2.1.4.1 Thermogravimetric Analysis. Thermogravimetric analysis measures the mass of a sample while its temperature is increased at a constant rate. Nitrogen is passed over the sample during heating to remove any released gases. Any decrease in the weight of a sample during analysis represents a loss of gaseous matter from the sample, through evaporation or through a reaction that forms gas phase products. The moisture content is estimated by 
assuming that all sample weight loss up to a certain temperature (typically 150 to $200{ }^{\circ} \mathrm{C}$ ) is caused by water evaporation. The temperature limit for moisture loss is chosen by the operator at an inflection point on the TGA plot. Other volatile matter fractions can also be differentiated by inflection points.

Tank 241-AP-101 samples were analyzed by TGA using procedure LA-514-114, Rev. C-1 on a Perkin-Elmer ${ }^{1}$ instrument. All samples exhibited a large weight loss between the ambient temperature and $200^{\circ} \mathrm{C}\left(392^{\circ} \mathrm{F}\right)$. In all runs, the weight loss occurred in one transition. Again, this weight loss is attributed to water evaporation. The TGA results are presented in Table B2-20.

Table B2-20. Tank 241-AP-101 Analytical Results: Weight Percent Water by Thermogravimetric Analysis.

\begin{tabular}{|c|c|c|c|c|c|c|c|}
\hline $\begin{array}{l}\text { Samigl } \\
\text { Whintic- }\end{array}$ & Riser & $\begin{array}{l}\text { gralo } \\
\text { Samine }\end{array}$ & \multicolumn{2}{|c|}{ Resill } & \multicolumn{2}{|c|}{ Surplicate } & nert. \\
\hline Supritivatint & & & 17.6 & 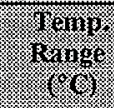 & 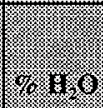 & $\begin{array}{l}\text { Tomp } \\
\text { Rringe } \\
192\end{array}$ & \\
\hline S95eT003722 & 1 at $210^{\circ}$ & $1 \mathrm{AP}-95-2$ & 60.56 & $35-170$ & 60.37 & $35-160$ & 60.47 \\
\hline S95T003721 & & $1 \mathrm{AP}-95-1$ & 59.69 & $35-170$ & 58.13 & $35-170$ & 58.91 \\
\hline S95T003723 & & 1AP-95-3 & 56.79 & $35-170$ & 56.85 & $35-170$ & 56.82 \\
\hline S95T003728 & 1 at $330^{\circ}$ & $1 \mathrm{AP}-95-4$ & 60.22 & $35-170$ & 60.36 & $35-180$ & 60.29 \\
\hline S95T003729 & & $1 \mathrm{AP}-95-5$ & 56.03 & $35-160$ & 56.96 & $35-200$ & 56.50 \\
\hline S95T003730 & & $1 \mathrm{AP}-95-6$ & 56.31 & $35-160$ & 56.63 & $35-160$ & 56.47 \\
\hline
\end{tabular}

Notes:

Temp. $=$ temperature

'All analyses were performed with á Perkin-Elmer ${ }^{(8)}$ instrument.

B2.1.4.2 Differential Scaning Calorimetry. Differential scanning calorimetry analysis measures the heat absorbed or emitted by a sample while the sample is heated at a constant rate. Nitrogen is passed over the sample material to remove any gases being released. The onset temperature for an endothermic or an exothermic event is determined graphically.

'Perkin Elmer is a registered trademark of Perkins Research and Manufacturing Company, Inc., Canoga Park, CA. 
The DSC analyses of the tank 241-AP-101 samples were performed using procedure LA-514-113, Rev. C-1 on a Mettler ${ }^{2}$ instrument or procedure LA-514-114, Rev. C-1 on a Perkin-Elmer ${ }^{\circledR}$ instrument. All samples exhibited an initial endothermic reaction, which represents the evaporation of free and interstitial water. Most samples exhibited endothermic reactions only. However, samples S95T003728 and S95T003730 exhibited exothermic reactions in the second transition. The magnitudes of the exotherms on a dry weight basis for these samples were 97.5 and $877 \mathrm{~J} / \mathrm{g}$, respectively. The 95 percent upper confidence interval values for these samples were 356.4 and $1,146 \mathrm{~J} / \mathrm{g}$, respectively (Esch 1996).

No additional analyses were required for sample S95T003728 because the 95 percent upper confidence interval value was below the safety screening decision criteria threshold of $480 \mathrm{~J} / \mathrm{g}$.

Sample S95T003730 exhibited no exothermic reactions in sample or triplicate analyses, only in the duplicate analysis. The chemist indicated that tank 241-AP-101 samples had a tendency to spill out of the sample pan and contaminate the sensor. However, this type of contamination would have been observed as "noise" in the baseline on the DSC thermogram. This "noise" was not evident on the duplicate scan. The analysis was rerun in duplicate with a new sensor installed. The exothermic reaction could not be reproduced in the rerun. It was concluded that the exothermic reaction in the original sample may have been caused by the presence of some anomalous material, originating from the sample (for example, a particle of suspended solids) or from a foreign material (for example, a piece of plastic "milling" from a pipet tip), which was present only in that sample portion (Esch 1996; Bushaw 1996). Therefore, no secondary analyses were requested (Esch 1996).

The DSC results, including peak temperatures and magnitude of enthalpy changes on a wet basis, are shown in Table B2-21.

${ }^{2}$ Mettler is a registered trademark of Mettler Electronics, Anaheim, CA. 
Table B2-21. Tank 241-AP-101 Analytical Results:

Differential Scanning Calorimetry.

\begin{tabular}{|c|c|c|c|c|c|c|c|c|c|}
\hline siminger & risser & Grininge & Tou & Thanisi & 1 fror 1 & 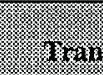 & (3in:on 2 & V1rinis & 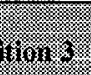 \\
\hline Sureriar & $\sqrt{13}$ & (3) & (3) & 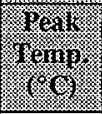 & 18 & 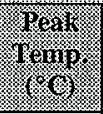 & $\frac{1}{41}$ & $\frac{1}{18 m}$ & 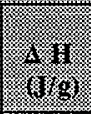 \\
\hline $3722^{2}$ & 1 at & 1AP-95-2 & 1 & 118 & 1,858 & 324 & 15.9 & -- & - \\
\hline & $210^{\circ}$ & & 2 & 119 & 1,612 & 236 & 10.6 & 324 & $16.8^{4}$ \\
\hline $3721^{2}$ & & 1AP-95-1 & 1 & 123 & 1,730 & 323 & 18.2 & -- & {$[-$} \\
\hline & & & 2 & 125 & 1,510 & 323 & 12.9 & -- & -- \\
\hline $3723^{2}$ & & 1AP-95-3 & 1 & 115 & 1,433 & 324 & 9.621 & -- & -- \\
\hline & & & 2 & 122 & 1,541 & 323 & 11.24 & $\cdots$ & {$[-$} \\
\hline $3728^{2}$ & 1 at & 1AP-95-4 & 1 & 129 & 1,305 & 231 & $38.7^{Q C: e}$ & 324 & 17.7 \\
\hline & $330^{\circ}$ & & 2 & 122 & 843.7 & 248 & $-38.7^{\mathrm{C}^{\mathrm{C}} \mathrm{c}}$ & 324 & $6.5^{3}$ \\
\hline $3729^{2}$ & & $1 \mathrm{AP}-95-5$ & 1 & 126 & 1,726 & 205 & 74.7 & 322 & $32.0^{3}$ \\
\hline & & & 2 & 118 & 1,117 & 323 & 9.9 & 436 & 41.8 \\
\hline $3730^{2}$ & 1 at & 1AP-95-6 & 1 & 118 & 1,912 & 322 & $10.4^{\mathrm{eC:}}$ & -- & -- \\
\hline$(12 / 95)^{4}$ & $330^{\circ}$ & & 2 & 121 & 1,392 & 395 & $-381.8^{Q C: e}$ & -- & -- \\
\hline & & & 3 & 143 & 1,486 & 322 & $10.0^{\mathrm{QC}: e}$ & -- & -- \\
\hline $3730^{2}$ & & 1AP-95-6 & 1 & 124 & 1,164 & 241 & 18.8 & 327 & 12.5 \\
\hline$(1 / 96)^{4}$ & & & 2 & 129 & 1,196 & 237 & 17.5 & 325 & 10.2 \\
\hline
\end{tabular}

Notes:

1Sample numbers begin with "S95T00."

${ }^{2}$ Analyses were performed with a Mettler ${ }^{(}$instrument.

${ }^{3}$ Fourth transitions have small endotherms measured between $442^{\circ} \mathrm{C}$ and $453^{\circ} \mathrm{C}$.

${ }^{4}$ Dates are in the $\mathrm{mm} / \mathrm{yy}$ format. 


\begin{tabular}{|c|c|c|c|c|c|}
\hline$\varepsilon 6^{\circ} \varepsilon \mathrm{I}$ & $\varepsilon 6^{\circ} \mathcal{E}$ & $26^{\circ} \varepsilon \mathrm{I}$ & 9-S6-đVI & \multirow[b]{3}{*}{$.0 E E$ TE I } & $0 \varepsilon \angle \varepsilon 00 L S 6 \mathrm{~S}$ \\
\hline$โ 6^{\circ} \varepsilon \mathrm{I}$ & $\varepsilon \sigma^{\circ} \varepsilon \tau$ & $06^{\circ} \varepsilon \mathrm{I}$ & $\varsigma-\varsigma 6-d \forall I$ & & $6 Z \angle E 00 L S 6 S$ \\
\hline $\mathrm{S} 6^{\circ} \varepsilon \mathrm{I}$ & $S 6^{\circ} \mathrm{EI}$ & $\$ 6^{\circ} \varepsilon \mathrm{I}$ & $t-\varsigma 6-d v I$ & & $8 Z L E 00 L S 6 S$ \\
\hline $98^{\circ} \mathrm{EI}$ & $\angle 8^{\circ} \varepsilon \tau$ & $98^{\circ} \varepsilon \mathrm{I}$ & $\varepsilon-\varsigma 6-d \forall I$ & \multirow[b]{3}{*}{ ○IZ IE I } & $\varepsilon Z L \varepsilon 00 L S 6 S$ \\
\hline$\angle L^{\cdot} \varepsilon I$ & $8 L^{\circ} \mathcal{E} \mathrm{I}$ & $L L^{\circ} \varepsilon I$ & $I-S_{6}-\mathrm{dVI}$ & & $I Z L E 00 \perp S 6 S$ \\
\hline$\angle 8^{\circ} \varepsilon \mathrm{I}$ & $88^{\circ} \mathcal{E} I$ & $98^{\circ} \varepsilon \mathrm{I}$ & $\tau-S 6-\mathrm{dVI}$ & & $\tau Z L \varepsilon 00 \perp S 6 S$ \\
\hline & & & & & grmueriadnis \\
\hline ngand & & & ridings & 2 & raquine \\
\hline
\end{tabular}

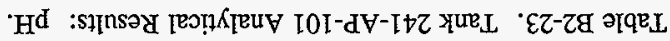

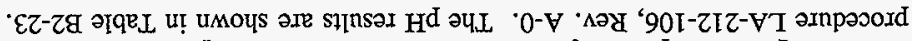

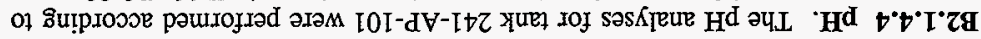

\begin{tabular}{|c|c|c|c|c|c|}
\hline $0 S E^{\circ} \mathrm{I}$ & $0 \varepsilon \varepsilon^{\prime} \mathrm{I}$ & $0 \angle E^{\circ} I$ & $9-\varsigma 6-d \forall I$ & \multirow[b]{3}{*}{.OEE I I I } & $0 \varepsilon \angle E 00 L S 6 \mathrm{~S}$ \\
\hline$\$ 6 Z^{\circ} I$ & $00 \varepsilon^{\circ} \mathrm{I}$ & $062^{\circ} \mathrm{I}$ & s-S6-dVI & & 6ZLE00LS6S \\
\hline$S \angle Z^{\circ} I$ & $092^{\circ} 1$ & $062^{\circ} \mathrm{I}$ & $t-\varsigma 6-\mathrm{dVI}$ & & $8 Z L E 00 L S 6 \mathrm{~S}$ \\
\hline $0+\varepsilon^{\prime} I$ & $09 \varepsilon^{\circ} \mathrm{I}$ & $0 z \varepsilon^{\circ} \mathrm{I}$ & $\varepsilon-\varsigma 6-d V I$ & \multirow[b]{3}{*}{.OIZ 证 I } & $\varepsilon Z \angle E 00 L S 6 \mathrm{~S}$ \\
\hline$S 8 Z^{\circ} I$ & $062^{\circ} \mathrm{I}$ & $08 \tau^{*} \mathrm{I}$ & I-S6-dVI & & IZLE00LS6S \\
\hline$\$ 6 Z^{\circ} \mathrm{I}$ & $00 \varepsilon^{\circ} \mathrm{I}$ & $062 \cdot I$ & $z-\varsigma 6-\mathrm{dVI}$ & & ZZLE00LS6S \\
\hline & & & & & 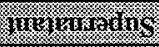 \\
\hline 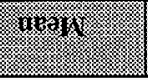 & 91 boum ind & Insidy & 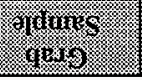 & 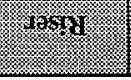 & 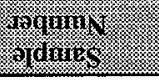 \\
\hline
\end{tabular}

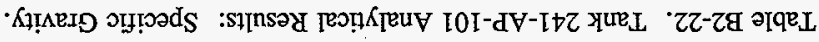

¿२-२६ ग१QL

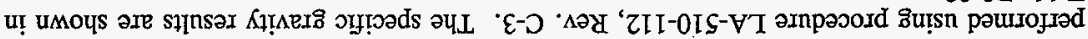

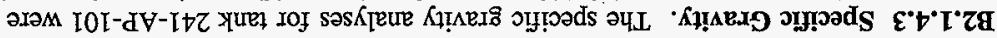




\section{B2.1.5 Vapor Phase Measurement}

Before the November 1995 grab sampling of tank 241-AP-101, vapor phase measurements were taken as required by the safety screening DQO (Dukelow et al. 1995). The vapor phase screening was done for flammability issues. The vapor phase measurements were taken from risers 1 at $210^{\circ}$ and 1 at $330^{\circ}$ in the headspace of the tank according to procedures IH 1.4 and IH 2.1 (WHC 1996). The results were obtained in the field (that is, no gas sample was sent to the laboratory for analysis). The combustible gas meter used to sample the vapor phase measures flammability as a percent of the lower explosive limit. Because the National Fire Protection Association defines the terms lower explosive limit and LFL identically, the two terms may be used interchangeably (NFPA 1995). The results of the vapor phase measurements are provided in Table B2-24.

Table B2-24. Vapor Phase Measurement Results for Tank 241-AP-101.

\begin{tabular}{|c|c|c|}
\hline \multirow{2}{*}{ 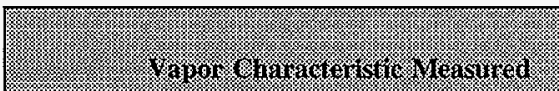 } & \multicolumn{2}{|c|}{ (4osinin } \\
\hline & Miser. I / 2010 & 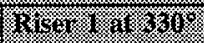 \\
\hline Vapor flammability as percent of LFL & $0 \%$ & $0 \%$ \\
\hline Oxygen & $20.7 \%$ & $20.8 \%$ \\
\hline Ammonia & 125 ppmv & $<200 \mathrm{ppmv}$ \\
\hline Total organic carbon & $9.8 \mathrm{ppmv}$ & $7.9 \mathrm{ppmv}$ \\
\hline
\end{tabular}

Note:

ppmv $=$ parts per million by volume

\section{B2.2 TANK 241-AW-106 ANALYTICAL RESULTS}

This section summarizes the analytical results associated with the July 1995 sampling of 242-A Evaporator slurry and the subsequent August 1995 sampling of tank 241-AW-106. These results provide characterization data for waste that was transferred from tank 241-AW-106 into tank 241-AP-101 in March 1996 and January 1997. The results for Evaporator slurry sampling are documented in Guthrie (1996). The results for tank 241-AW-106 sampling are documented in Esch (1995b). This discussion does not address tank 241-AW-106 sludge samples because only supernatant was transferred to tank 241-AP-101.

No information is available regarding QC parameters associated with the Evaporator slurry sample. The four QC parameters assessed in conjunction with the tank 241-AW-106 samples were standard recoveries, spike recoveries, duplicate analyses (RPDs), and blanks. The QC criteria specified in the SAP (Jones 1995) were 80 to 120 percent for standards and spikes 


\begin{tabular}{|c|c|c|c|c|}
\hline $50-\exists 8 \mathcal{E}^{\circ} \mathrm{I}$ & $\mathrm{e} / \mathrm{u}$ & $\pm 0-\bar{g} 8 \varepsilon \cdot \mathrm{I}$ & $t 0-986^{\circ} z$ & $0 † Z / 6 \varepsilon z$-untuolnn]d \\
\hline S0-日十8 & $\mathrm{e} / \mathrm{u}$ & $S 0^{-}-\underline{2} t 8^{\circ} t>$ & $S 0-\exists \angle S^{\circ} 8>$ & 8EZ-unṇuo!nโโd \\
\hline ZELO $0>$ & $\mathrm{e} / \mathrm{U}$ & $2 E I 0^{\circ} 0>$ & $\angle S I 0^{\circ} 0>$ & †6-untqợN \\
\hline s0-보이 & $\mathrm{e} / \mathrm{u}$ & $S 0-790^{\circ} z>$ & $S 0^{-}-\underline{9} 90^{\circ} z>$ & LEZ-un!̣umdəN \\
\hline S0-39L's & $e / \mathrm{u}$ & $\mathrm{S} 0-39 L^{\circ} \mathrm{s}$ & $50-300^{\circ} 9$ & 6ZI-әu!poI \\
\hline $9 \angle 90^{\circ} 0>$ & $\mathrm{e} / \mathrm{u}$ & $9 \angle 90^{\circ} 0>$ & $8 \mathrm{SI}^{\circ} 0>$ & SSI-un!doIng \\
\hline $9 z z 0^{\circ} 0>$ & $\mathrm{e} / \mathrm{u}$ & $9220^{\circ} 0>$ & $9+70^{\circ} 0>$ & $t S I$-un!doIng \\
\hline $60100^{\circ} 0>$ & $\mathrm{e} / \mathrm{u}$ & $60100^{\circ} 0>$ & $t 0^{-}-380^{\circ} \varepsilon>$ & $\triangleright \succsim Z / \varepsilon \triangleright \tau$-un!̣no \\
\hline $9 \tau+00^{\circ} 0>$ & $\mathrm{e} / \mathrm{u}$ & $9 z+00^{\circ} 0>$ & $7810^{\circ} 0>$ & 09-1теqоo \\
\hline ZII & $\mathrm{e} / \mathrm{u}$ & $0.2 I I$ & $Z \nabla I$ & LEI-UunIsəo \\
\hline$\nabla 2 z \circ 0$ & $\mathrm{e} / \mathrm{u}$ & $\nabla z z^{\circ} 0$ & $80 \varepsilon^{\circ} 0$ & $\nabla \varepsilon I-$ unțIsa \\
\hline $262^{\circ} 0>$ & $\mathrm{e} / \mathrm{u}$ & $26 \tau^{\circ} 0>$ & ISE $0>$ & $\nabla \forall[$ - \\
\hline t0-GSE'I & $\mathrm{e} / \mathrm{u}$ & †0"포 I & $70^{-}-\exists \neq L^{\circ} I$ & $\downarrow I$-uoqIe? \\
\hline $60100^{\circ} 0>$ & $\mathrm{e} / \mathrm{u}$ & $60100^{\circ} 0>$ & t0-घ̈2s'9 & I† \\
\hline 8.76 & $\mathrm{e} / \mathrm{u}$ & $08^{\circ}+6$ & $\nabla \nabla \mathrm{I}$ & 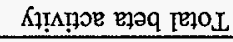 \\
\hline$\downarrow \varepsilon I 0^{\circ} 0>$ & $\mathrm{E} / \mathrm{U}$ & $\nabla \varepsilon 10^{\circ} 0>$ & $66200^{\circ} 0>$ & 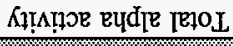 \\
\hline grang: & max & 4aryist & 3in & S.73) \\
\hline 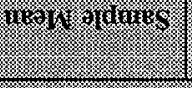 & 946) & 3115rod & \multirow{2}{*}{ 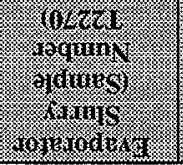 } & \multirow[t]{2}{*}{ 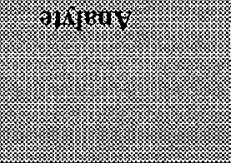 } \\
\hline 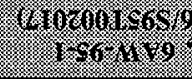 & 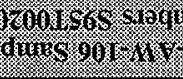 & (196) & & \\
\hline
\end{tabular}

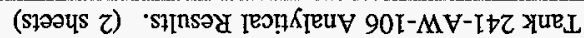

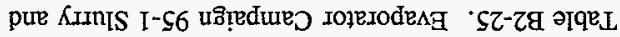

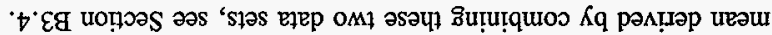

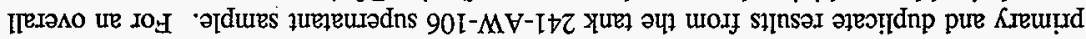

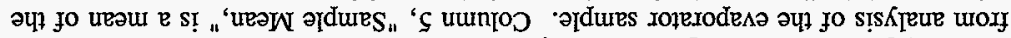

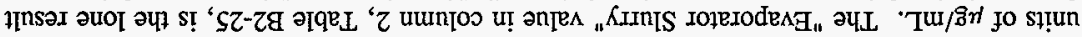

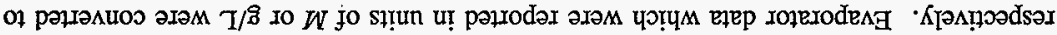

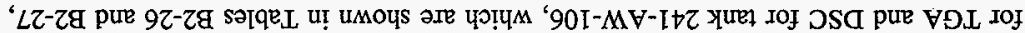

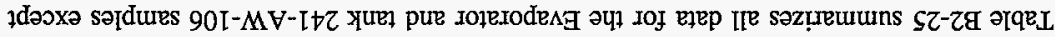

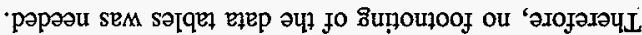

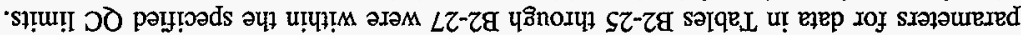

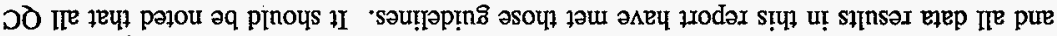

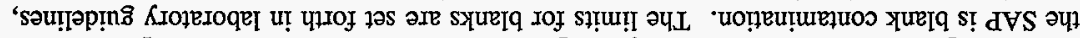

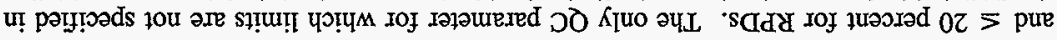


Table B2-25. Evaporator Campaign 95-1 Slurry and

Tank 241-AW-106 Analytical Results. (2 sheets)

\begin{tabular}{|c|c|c|c|c|}
\hline ( & 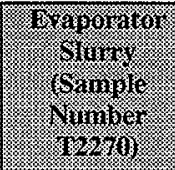 & 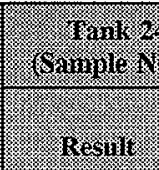 & 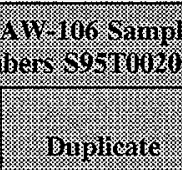 & 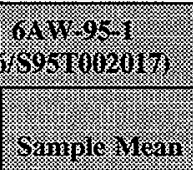 \\
\hline $\begin{array}{l}\text { Morionichiles: } \\
\text { Contimind: }\end{array}$ & (7) & 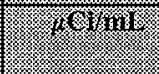 & 1.191 & I. TIOI: \\
\hline Radium-226 & $<1.48$ & $<0.646$ & $n / a$ & $<0.646$ \\
\hline Ruthenium/Rhodium-106 & $<1.17$ & $<0.429$ & $\mathrm{n} / \mathrm{a}$ & $<0.429$ \\
\hline Selenium-79 & $8.81 \mathrm{E}-05$ & $1.22 \mathrm{E}-04$ & $\mathrm{n} / \mathrm{a}$ & $1.22 \mathrm{E}-04$ \\
\hline Strontium-89/90 & 0.164 & 0.0339 & $n / a$ & 0.0339 \\
\hline Technetium-99 & 0.0291 & 0.0352 & $n / a$ & 0.0352 \\
\hline Tritium & 0.00570 & 0.0113 & $\mathrm{n} / \mathrm{a}$ & 0.0113 \\
\hline \multicolumn{5}{|l|}{ 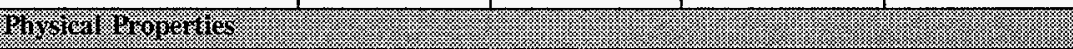 } \\
\hline Specific gravity & 1.309 & 1.220 & 1.210 & 1.215 \\
\hline $\mathrm{pH}$ & 13.5 & 14.19 & 14.16 & 14.18 \\
\hline Meris. & 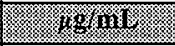 & (1) & 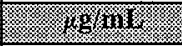 & 18.101 \\
\hline Aluminum & 5,290 & 4,600 & 4,580 & 4,590 \\
\hline Iron & $n / a$ & $<20.05$ & $<20.05$ & $<20.05$ \\
\hline Sodium & $1.20 \mathrm{E}+05$ & $1.03 \mathrm{E}+05$ & $1.03 \mathrm{E}+05$ & $1.03 \mathrm{E}+05$ \\
\hline Uranium & 67.2 & 71.10 & $\mathrm{n} / \mathrm{a}$ & 71.1 \\
\hline 4rions catilon & 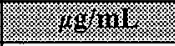 & 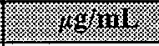 & $6.28 \times 1$ & . $69.1 \%$ \\
\hline Ammonia & 2.94 & $\mathrm{n} / \mathrm{a}$ & $n / a$ & $\mathrm{n} / \mathrm{a}$ \\
\hline Chloride & $n / a$ & 1,340 & $n / a$ & 1,340 \\
\hline Fluoride & 2,740 & 3,870 & $\mathrm{n} / \mathrm{a}$ & 3,870 \\
\hline Hydroxide & 31,500 & 27,500 & 27,900 & 27,700 \\
\hline Nitrate & 95,500 & 92,900 & $\mathrm{n} / \mathrm{a}$ & 92,900 \\
\hline Nitrite & 40,500 & 37,300 & $n / a$ & 37,300 \\
\hline Phosphate & 1,190 & 1,930 & $n / a$ & 1,930 \\
\hline Sulfate & 5,780 & 5,510 & $n / a$ & 5,510 \\
\hline Caranou & 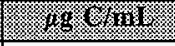 & 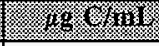 & $18.07 m$ & 13 - \\
\hline Total carbon & 12,600 & 27,100 & 27,800 & 27,400 \\
\hline TIC & 9,060 & 8,220 & 8,380 & 8,300 \\
\hline TOC & 3,310 & 5,510 & 5,080 & 5,300 \\
\hline
\end{tabular}


Table B2-26. Tank 241-AW-106 Analytical Results: Weight Percent Water.

\begin{tabular}{|c|c|c|c|c|c|}
\hline Thanger & 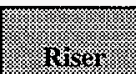 & Sinnilo & & Resuil: & . \\
\hline Sijgeniatan & & & 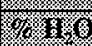 & 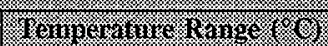 & 826 \\
\hline S95T002016 & $16 \mathrm{~B}$ & 6AW-95-1 & 68.88 & 35 to 190 & 68.9 \\
\hline
\end{tabular}

Note:

${ }^{1}$ The analysis was performed with a Mettler ${ }^{\mathbb{B}}$ instrument.

Table B2-27. Tank 241-AW-106 Analytical Results: Differential Scanning Calorimetry. ${ }^{1}$

\begin{tabular}{|c|c|c|c|c|}
\hline Sinumber & inisis: & Samingle & Thanili & (1) \\
\hline Sunernatany & & & Heal (remperating ( ( ) & 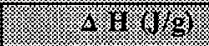 \\
\hline S95T002016 & $16 \mathrm{~B}$ & $6 \mathrm{AW}-95-1$ & 113 & 1,869 \\
\hline
\end{tabular}

Notes:

${ }^{1}$ No exotherms were found in the Evaporator sample. However, no other information was provided.

${ }^{2}$ The analysis was performed using Perkin-Elmer ${ }^{2}$ instrument.

Viscosity measurements were also made on sample 6AW-95-1 at $25^{\circ} \mathrm{C}$ and $44{ }^{\circ} \mathrm{C}$ (Esch 1995a). The viscosities were recorded with shear rates increasing from $0 \mathrm{~s}^{-1}$ to $300 \mathrm{~s}^{-1}$ and decreasing from $300 \mathrm{~s}^{-1}$ to $0 \mathrm{~s}^{-1}$. At $25^{\circ} \mathrm{C}$, the sample exhibited the non-Newtonian behavior of viscosity decreasing with shear rate. Above a $50 \mathrm{~s}^{-1}$ shear rate, the viscosity remained constant at approximately 4 centipoise. Crystal formation during the $44^{\circ} \mathrm{C}$ run caused the viscosity curve to be erratic. No further interpretation of the results from the run at this temperature were made, but the raw data were included in Esch (1995b). Performance checks were made with 10 centipoise and 100 centipoise certified Newtonian standards before the sample runs. The performance checks were within the required 20 percent range. See Esch (1995b) for all raw viscosity data and viscosity versus shear rate curves.

\section{B2.3 HISTORICAL SAMPLE RESULTS}

Three historical sampling events have been identified for tank 241-AP-101. Grab sampling was performed in March 1995, December 1994, and July 1993. However, because of significant changes in the waste composition through transfer activity, results from these three sampling events may no longer reflect current contents. Therefore, these results should be used with caution. 


\section{B2.3.1 Results from March 1995 Grab Sampling}

Table B2-28 summarizes the results of the March 1995 grab sampling of tank 241-AP-101. Two grab samples were analyzed, and the results were reported in Rollison (1995a). As stated in Section B1.3.1, conflicting information exists about sample numbering. According to Rollison (1995a), grab sample 1AP-95-2 was assigned laboratory identification number S95T000340 and grab sample 1AP-95-3 was given number S95T000342 at the laboratory. No duplicate was performed for the IC analyses. The mean in column 6 is a mean of all individual primary and duplicate results.

Table B2-28. Results from March 1995 Grab Sampling.

\begin{tabular}{|c|c|c|c|c|c|}
\hline \multirow{3}{*}{$\sqrt{2}$} & \multicolumn{2}{|c|}{ 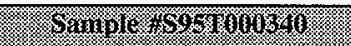 } & \multicolumn{2}{|c|}{ Samule 59921000342} & \multirow{2}{*}{ 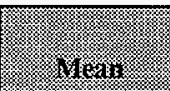 } \\
\hline & Revill: & 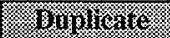 & Hessill: & Dorilleat & \\
\hline & I. & 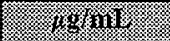 & (196/in & (1) & 149610 \\
\hline Chloride & 66.9 & -- & 65.5 & -- & 66.2 \\
\hline Fluoride & 3,730 & --- & 3,600 & $\cdots$ & 3,670 \\
\hline Hydroxide & 5,530 & 5,460 & 5,690 & 5,630 & 5,580 \\
\hline Nitrate & 10,000 & -- & 9,990 & -- & 10,000 \\
\hline Nitrite & 1,560 & $\ldots$ & 1,520 & -- & 1,540 \\
\hline Phosphate & 142 & -- & 147 & -- & 145 \\
\hline Sulfate & 329 & -- & 330 & $\ldots$ & 330 \\
\hline TIC & 342 & 345 & 347 & 353 & 347 \\
\hline pH (unitless) & 13.23 & 13.25 & 13.27 & 13.28 & 13.26 \\
\hline
\end{tabular}

\section{B2.3.2 Results from December 1994 Grab Sampling}

Two grab samples were taken from tank 241-AP-101 in December 1994 and analyzed for anion and TIC content and for $\mathrm{pH}$. Results from the sampling event were reported in Rollison (1995b). The data sheets in Rollison (1995b) report the laboratory identification numbers as R 6833 and R 6834. No distinction was made in Rollison (1995b) about which grab sample matched which laboratory identification number. Table B2-29 shows the results from the December 1994 sampling. Because no duplicates were performed for the analyses, the table does not include a "Duplicate" column. The mean in column 4 is a mean of two results. 
Table B2-29. Results from December 1994 Grab Sampling.

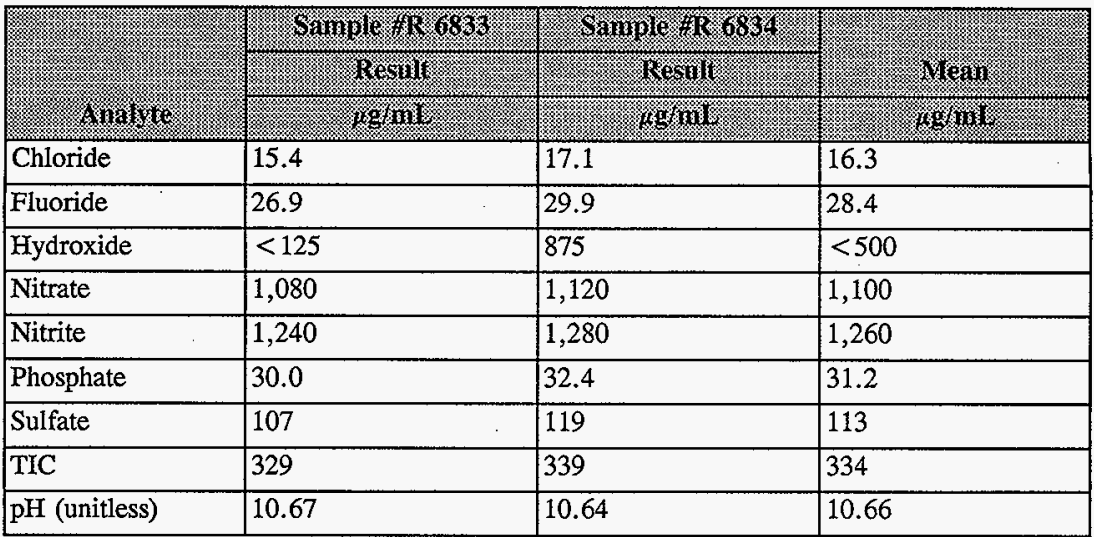

\section{B2.3.3 Results from July 1993 Grab Sampling}

Table B2-30 summarizes the results of the July 20, 1993, grab sampling of tank 241-AP-101 as reported in DiCenso et al. (1994). Table B2-30 shows only overall mean results. Refer to Dicenso et al. for more detailed information.

The overall mean results were calculated using a straight average of the sample means from all grab samples. Results, which were rejected based on validation guidelines or were below the detection limit (indicated by the less-than symbol " $<$ "), were not used in calculating the overall means. If all results for an analyte were below the detection limit, then the detection limit was used for the overall mean.

Table B2-30 does not include the data for a wide range of volatile and semivolatile organics because no organics were detected, and no detection limits were specified in DiCenso et al. (1994). 
Table B2-30. 1993 Historical Data Summary for Tank 241-AP-101. (2 sheets)

\begin{tabular}{|c|c|c|c|}
\hline 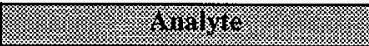 & 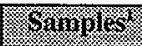 & (6) wall 1 1ran & 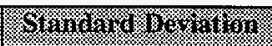 \\
\hline Menis & $H_{1>>>}$ & 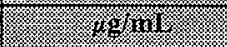 & ?. \\
\hline Aluminum & 5 & 0.667 & 0.277 \\
\hline Arsenic & 0.00 & $<0.013$ & $\mathrm{n} / \mathrm{a}$ \\
\hline Barium & 2 & 0.226 & $n / a$ \\
\hline Calcium & 0.00 & $<10.0$ & $n / a$ \\
\hline Cadmium & 3 & 0.143 & 0.098 \\
\hline Chromium & 3 & 0.0393 & 0.00127 \\
\hline Iron & 4 & 0.281 & 0.079 \\
\hline Lead & 3 & 0.445 & 0.325 \\
\hline Mercury & 0.00 & $<0.005$ & $n / a$ \\
\hline Magnesium & 4 & 0.657 & 0.136 \\
\hline Manganese & 0.00 & $<0.0150$ & $\mathrm{n} / \mathrm{a}$ \\
\hline Selenium & 1 & 0.014 & $n / a$ \\
\hline Sodium & 5 & 1,290 & 107 \\
\hline Uranium & 1 & 0.212 & $n / a$ \\
\hline Zinc & 4 & 0.494 & 0.644 \\
\hline Anion_carions & 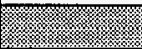 & 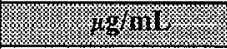 & I. \\
\hline Ammonia & 5 & 1,960 & 91.5 \\
\hline Chloride & 0.00 & $<22.0$ & $\mathrm{n} / \mathrm{a}$ \\
\hline Cyanide & 5 & 0.34 & 0.041 \\
\hline Fluoride & 5 & 68.6 & 1.01 \\
\hline Hydroxide & 5 & 1,820 & 121 \\
\hline Nitrate & 5 & 1,580 & 4.47 \\
\hline Nitrite & 5 & 13,400 & 207 \\
\hline Phosphate & 0.00 & $<10$ & $n / a$ \\
\hline Sulfate & 5 & 86.2 & 0.421 \\
\hline frordioniandidos & (2) & 40.1401111 & : \\
\hline${ }^{241}$ Am (Alpha energy analysis) & 0 & $<3.18 \mathrm{E}-04$ & $n / a$ \\
\hline${ }^{241} \mathrm{Am}$ (GEA) & 0 & $<0.00136$ & $\mathrm{n} / \mathrm{a}$ \\
\hline${ }^{14} \mathrm{C}$ & 0 & $<4.66 \mathrm{E}-06$ & $\mathrm{n} / \mathrm{a}$ \\
\hline${ }^{144} \mathrm{Ce} / \mathrm{Pr}$ & 0 & $<0.0212$ & $\mathrm{n} / \mathrm{a}$ \\
\hline
\end{tabular}


Table B2-30. 1993 Historical Data Summary for Tank 241-AP-101. (2 sheets)

\begin{tabular}{|c|c|c|c|}
\hline 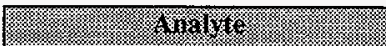 & (5) & 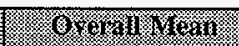 & 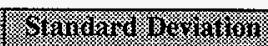 \\
\hline 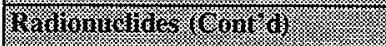 & 13 & 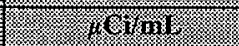 & IV \\
\hline${ }^{134} \mathrm{Cs}$ & 0 & $<2.88 \mathrm{E}-04$ & $\mathrm{n} / \mathrm{a}$ \\
\hline${ }^{137} \mathrm{Cs}$ & 1 & 0.00326 & $\mathrm{n} / \mathrm{a}$ \\
\hline${ }^{{ }^{\circ} \mathrm{Co}}$ & 0 & $<<2.73 \mathrm{E}-04$ & $n / a$ \\
\hline${ }^{243 / 244} \mathrm{Cm}$ & 0 & $<3.18 \mathrm{E}-04$ & $n / a$ \\
\hline${ }^{154} \mathrm{Eu}$ & 0 & $<9.68 \mathrm{E}-04$ & $n / a$ \\
\hline${ }^{155} \mathrm{Eu}$ & 0 & $<6.53 \mathrm{E}-04$ & $n / a$ \\
\hline${ }^{129} \mathrm{I}$ & 0 & $<4.08 \mathrm{E}-05$ & $n / 2$ \\
\hline${ }^{237} \mathrm{~Np}$ & 0 & $<4.70 \mathrm{E}-05$ & $n / a$ \\
\hline${ }^{94} \mathrm{Nb}$ & 0 & $<<2.49 \mathrm{E}-04$ & $\mathrm{n} / \mathrm{a}$ \\
\hline${ }^{238} \mathrm{Pu}$ & 0 & $<3.02 \mathrm{E}-04$ & $n / a$ \\
\hline${ }^{239 / 240} \mathrm{Pu}$ & 0 & $<2.13 \mathrm{E}-04$ & $n / a$ \\
\hline${ }^{226} \mathrm{Ra}$ & 0 & $<0.00465$ & $n / a$ \\
\hline${ }^{103} \mathrm{Ru}$ & 0 & $<2.35 \mathrm{E}-04$ & $\mathrm{n} / \mathrm{a}$ \\
\hline${ }^{106} \mathrm{Ru} / \mathrm{Rh}$ & 0 & $<0.00473$ & $\mathrm{n} / \mathrm{a}$ \\
\hline${ }^{79} \mathrm{Se}$ & 0 & $<6.15 \mathrm{E}-06$ & $\mathrm{n} / \mathrm{a}$ \\
\hline${ }^{8990} \mathrm{Sr}$ & 1 & $5.63 \mathrm{E}-04$ & $\mathrm{n} / \mathrm{a}$ \\
\hline${ }^{99} \mathrm{Tc}$ & 0 & $<3.07 \mathrm{E}-05$ & $n / a$ \\
\hline${ }^{3} \mathrm{H}$ & 1 & 0.00210 & $n / a$ \\
\hline Total alpha & 1 & $5.94 \mathrm{E}-06$ & $\mathrm{n} / \mathrm{a}$ \\
\hline Total beta & 1 & 0.00548 & $\mathrm{n} / \mathrm{a}$ \\
\hline (2anon. & 8 & 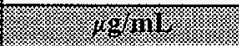 & (1) \\
\hline TIC & 5 & 190 & 6.08 \\
\hline TOC & 3 & 23.7 & 15.1 \\
\hline \multicolumn{4}{|l|}{ 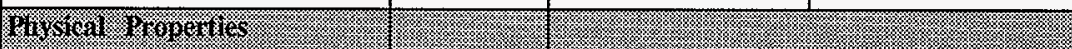 } \\
\hline Specific gravity & 5 & 0.986 & 0.00182 \\
\hline
\end{tabular}

Note:

${ }^{1}$ The number of samples used for overall mean and standard deviation calculations. Rejected and nondetected data were not used in calculations. 


\section{B3.0 ASSESSMENT OF CHARACTERIZATION RESULTS}

The purpose of this section is to discuss overall quality and consistency of current sampling results for tanks 241-AP-101 and 241-AW-106 and the evaporator slurry sample from Evaporator Campaign 95-1 and to identify limitations in data use. This is accomplished by evaluating sampling and analysis factors that may impact data interpretation. In addition, internal data checks are performed.

\section{B3.1 FIELD OBSERVATIONS}

Because different depths from two separate risers were sampled during the November 1995 grab sampling event for tank 241-AP-101, the safety screening DQO requirement that vertical profiles of the waste be obtained from at least two widely spaced risers was fulfilled. No problems were recorded for the November 1995 grab sampling event. Esch (1996) did note that the sampling depths for 1AP-95-1 and 1AP-95-2 were switched from those indicated in the SAP (that is, 1AP-95-1 was taken from a lower depth than 1AP-95-2). However, this did not compromise or impact the usefulness of the data.

No problems were noted during the August 1995 grab sampling of the tank 241-AW-106 supernatant (later transferred into tank 241-AP-101). Little sampling information was available for the slurry sample taken during the Evaporator Campaign 95-1. However, no problems with the sampling were noted in Guthrie (1996).

\section{B3.2 QUALITY CONTROL ASSESSMENT}

The usual QC assessment includes an evaluation of the appropriate standard recoveries, matrix spike recoveries, duplicate analyses, and blanks that are performed in conjunction with the chemical analyses. All the pertinent QC tests were conducted on the grab samples from the November 1995 tank 241-AP-101 sampling event and the August 1995 tank 241-AW-106 sampling event. The specific criteria for the QC checks were provided in the tank 241-AP-101 SAP (Esch 1995b) and the tank 241-AW-106 SAP (Jones 1995). Appendix B identifies QC results outside of the given criteria by superscripts in the data tables. This section summarizes the QC results. No QC information was available for the evaporator slurry sample from Campaign 95-1. Because no QC problems were found during the analysis of the tank 241-AW-106 sample, the following discussion focuses on tank 241-AP-101 samples.

The standard and matrix spike recovery results provide an estimate of the analysis accuracy. If a standard or spike recovery is above or below the given criterion, the analytical results may be biased high or low, respectively. All standard and spike recoveries were within the defined criteria. Analytical precision is estimated by the RPD, which is defined as the absolute value of the difference between the primary and duplicate samples, divided by their 
mean, times 100 . Only fluoride and the DSC analysis for tank 241-AP-101 had RPDs outside of the desired range. One of six fluoride samples had an RPD slightly above the criterion, and two DSC samples had RPDs above the criterion. For both DSC samples, an RPD was caused when an exothermic reaction was not observed in the primary run but was exhibited during the duplicate run. Finally, no sample exceeded the criteria for preparation blanks; therefore, contamination was not a problem for any analyte.

In summary, all QC results were within the boundaries specified in the SAPs (Esch 1995b and Jones 1995). The few discrepancies should not impact data validity or use.

\section{B3.3 DATA CONSISTENCY CHECKS}

Different analytical methods can be compared to assess data consistency and quality. The data set enabled the following comparisons: total alpha activity to the sum of the activities of the individual alpha emitters, total beta activity to the sum of the individual beta emitters, and mass to charge balances. Where possible, comparisons were made for tank 241-AP-101 analytical data and for data for tank 241-AW-106 supernatant which was transferred to tank 241-AP-101 in March 1996 and January 1997 (includes tank 241-AW-106 grab sample results and 242-A Evaporator Campaign 95-1 slurry sample results). Mass and charge balances also were performed.

\section{B3.3.1 Comparison of Results from Different Analytical Methods}

The following data consistency checks compare results from two analytical methods. Close agreement between the two methods strengthens the credibility of both results, but poor agreement brings the reliability of the data into question. All analytical mean results were taken from Section B3.4.

A comparison was made between the measured total alpha activity and the sum of the activities of the alpha-emitting radionuclides (see Table B3-1). The sum of the activities of the individual alpha emitters was determined by adding the ${ }^{241} \mathrm{Am}$ and ${ }^{239 / 240} \mathrm{Pu}$ activities. (No other alpha-emitting radionuclides were present in detectable quantities.) A true comparison could not be made because all results from the total alpha activity analysis were below the detection limit. However, the total alpha activity results indicated the sum of the activities of the individual alpha emitters should be less than 0.00263 and $0.00820 \mu \mathrm{Ci} / \mathrm{mL}$, respectively (based on a mean of the nondetect values) for tank 241-AP-101 and tank 241-AW-106 data. This expectation was confirmed, as the sum of the activities of the individual alpha emitters were $4.89 \mathrm{E}-04$ and $0.00109 \mu \mathrm{Ci} / \mathrm{mL}$. 
Table B3-1. Comparison of Total Alpha Activity with the Sum of the Activities of the Individual Alpha Emitters.

\begin{tabular}{|c|c|c|}
\hline . & 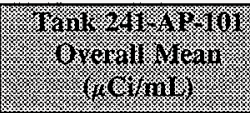 & 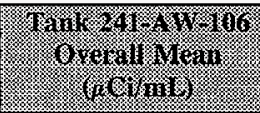 \\
\hline${ }^{241} \mathrm{Am}$ & $3.25 \mathrm{E}-04$ & $8.71 \mathrm{E}-04^{1}$ \\
\hline${ }^{239 / 240} \mathrm{Pu}$ & 1.64E-04 & $2.18 \mathrm{E}-04$ \\
\hline Sum of alpha-emitter activities & $4.89 \mathrm{E}-04$ & 0.00109 \\
\hline Measured total alpha activity & $<0.00263^{1}$ & $<0.00820^{1}$ \\
\hline
\end{tabular}

Note:

'The reported value is a mean of the nondetected results.

A comparison was made between the measured total beta activity and the sum of the activities of the beta-emitting radionuclides. This comparison was only possible with the tank 241-AW-106 data set because total beta was not analyzed on tank 241-AP-101 grab samples. The sum of the activities of the individual beta emitters was calculated as follows:

$$
\text { sum of beta emitters }=2 *{ }^{89 / 90} \mathrm{Sr}+{ }^{137} \mathrm{Cs}
$$

The ${ }^{89 / 90} \mathrm{Sr}$ activity is multiplied by 2 because of its beta-emitting daughter product, ${ }^{90} \mathrm{Y}$. Table B3-2 shows there is close agreement between the two methods.

Table B3-2. Comparison of Total Beta Activity with the Sum of the Activities of the Individual Beta Emitters.

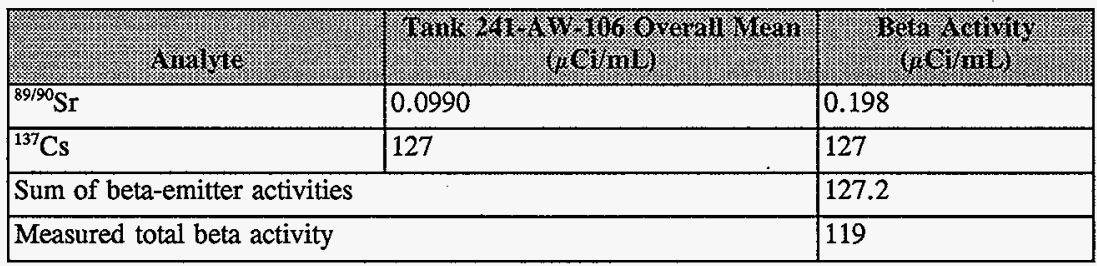




\section{B3.3.2 Mass and Charge Balances}

The principle objective in performing mass and charge balances is to determine whether measurements are consistent. Separate mass and charge balances were calculated for the tank 241-AP-101 grab sampling data set and the data set formed from the combination of the tank 241-AW-106 grab sample and evaporator slurry sample results. All analytes, which were present in detectable quantities and were listed in Section B3.4, were used in calculating the balances for tank 241-AP-101. All analytical results were converted from $\mu \mathrm{g} / \mathrm{mL}$ to $\mu \mathrm{g} / \mathrm{g}$ using the specific gravity mean of 1.31 . The analytes present in concentrations above 100 $\mu \mathrm{g} / \mathrm{mL}$ were used in calculating the balances for tank 241-AW-106 waste. All analytical results were first converted from $\mu \mathrm{g} / \mathrm{mL}$ to $\mu \mathrm{g} / \mathrm{g}$ using the specific gravity mean of 1.26 .

Table B3-3 shows cation mass and charge balance information. Because all waste in tank 241-AP-101 is supernatant, the aluminum was assumed to be present as the aluminate ion. All positive charge was attributed to sodium. The anionic analytes listed in Table B3-4 were assumed to be present as sodium salts and were expected to balance the positive charge. The concentrations of cationic species in Table B3-3, the anionic species in Table B3-4, and the percent water were ultimately used to calculate the mass balance.

The mass balance was calculated from the formula below. The factor 0.0001 is the conversion factor from $\mu \mathrm{g} / \mathrm{g}$ to weight percent.

$$
\begin{aligned}
\text { Mass balance }= & \text { Percent water }+0.0001 \times\{\text { total analyte concentration }\} \\
= & \text { Percent water }+0.0001 \times\left\{\mathrm{Na}^{+}+\mathrm{AlO}_{2}^{-}+\mathrm{C}_{2} \mathrm{H}_{3} \mathrm{O}_{2}^{-}+\mathrm{Cl}^{-}+\mathrm{CO}_{3}^{2-}+\right. \\
& \left.\mathrm{F}^{-}+\mathrm{NO}_{3}^{-}+\mathrm{NO}_{2}^{-}+\mathrm{OH}^{-}+\mathrm{PO}_{4}^{3-}+\mathrm{SO}_{4}^{2-}\right\}
\end{aligned}
$$

The total analyte concentrations calculated from the above equation for tank 241-AP-101 is $363,000 \mu \mathrm{g} / \mathrm{g}$ (wet weight). The mean weight percent water obtained from TGA is 58.2 percent or $582,000 \mu \mathrm{g} / \mathrm{g}$. The mass balance resulting from adding the percent water to the total analyte concentration is $945,000 \mu \mathrm{g} / \mathrm{g}$, or 94.5 percent (see Table B3-5).

The total analyte concentrations calculated from the above equation for the tank 241-AW-106 data set is $279,000 \mu \mathrm{g} / \mathrm{g}$ (wet weight). The mean weight percent water obtained from TGA is 68.9 percent or $689,000 \mu \mathrm{g} / \mathrm{g}$. The mass balance resulting from adding the percent water to the total analyte concentration is $968,000 \mu \mathrm{g} / \mathrm{g}$ or 96.8 percent (see Table B3-5).

The following equations demonstrate the derivation of total cations and total anions; the charge balance is the ratio of these two values. To derive the results shown in the equations, all concentrations must first be converted to a $\mu \mathrm{g} / \mathrm{g}$ basis. 
Total cations $=\left[\mathrm{Na}^{+}\right] / 23.0$

$=\quad 5,520 \mu \mathrm{eq} / \mathrm{g}(\operatorname{tank} 241-\mathrm{AP}-101)$

$=\quad 3,870 \mu \mathrm{eq} / \mathrm{g}(\operatorname{tank} 241-\mathrm{AW}-106)$

Total anions $=\left[\mathrm{AlO}_{2}{ }^{-}\right] / 59.0+\left[\mathrm{C}_{2} \mathrm{H}_{3} \mathrm{O}_{2}\right] / 59.0+[\mathrm{Cl}] / 35.5+\left[\mathrm{CO}_{3}{ }^{2-}\right] / 30.0+[\mathrm{F}] / 19.0$ $+\left[\mathrm{OH}^{-}\right] / 17.0+\left[\mathrm{NO}_{3}^{-}\right] / 62.0+\left[\mathrm{NO}_{2}^{-}\right] / 46.0+\left[\mathrm{PO}_{4}{ }^{3}\right] / 31.7+$

$\left[\mathrm{SO}_{4}^{2-}\right] / 48.0$

$=\quad 6,010 \mu \mathrm{eq} / \mathrm{g}(\operatorname{tank} 241-\mathrm{AP}-101)$

$=\quad 5,000 \mu \mathrm{eq} / \mathrm{g}(\operatorname{tank} 241-\mathrm{AW}-106)$

The charge balance obtained by dividing the sum of the positive charge by the sum of the negative charge was 0.92 for tank 241-AP-101 and 0.77 for tank 241-AW-106.

Table B3-3. Cation Mass and Charge Data.

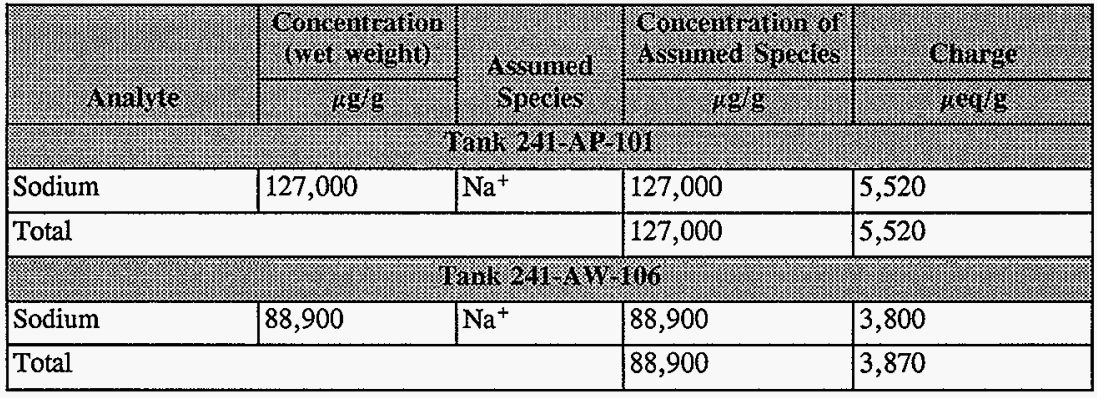

Table B3-4. Anion Mass and Charge Data. (2 sheets)

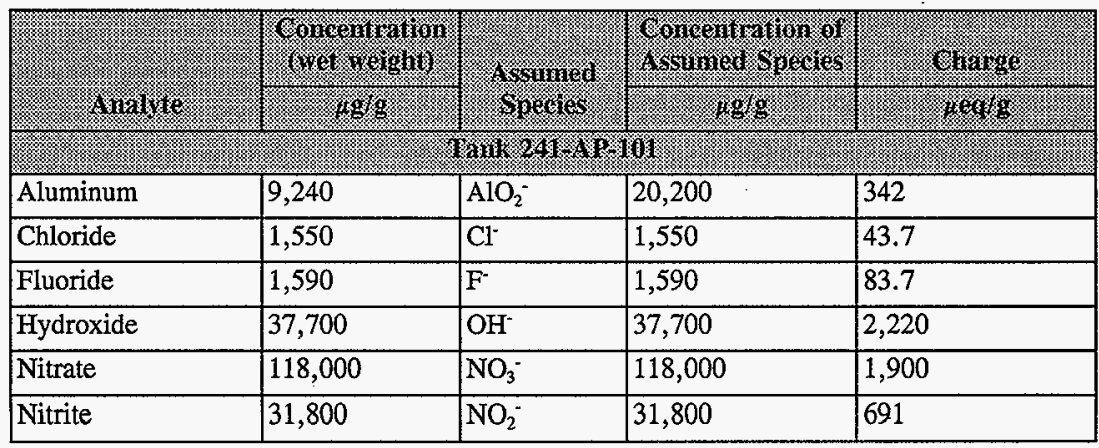


Table B3-4. Anion Mass and Charge Data. (2 sheets)

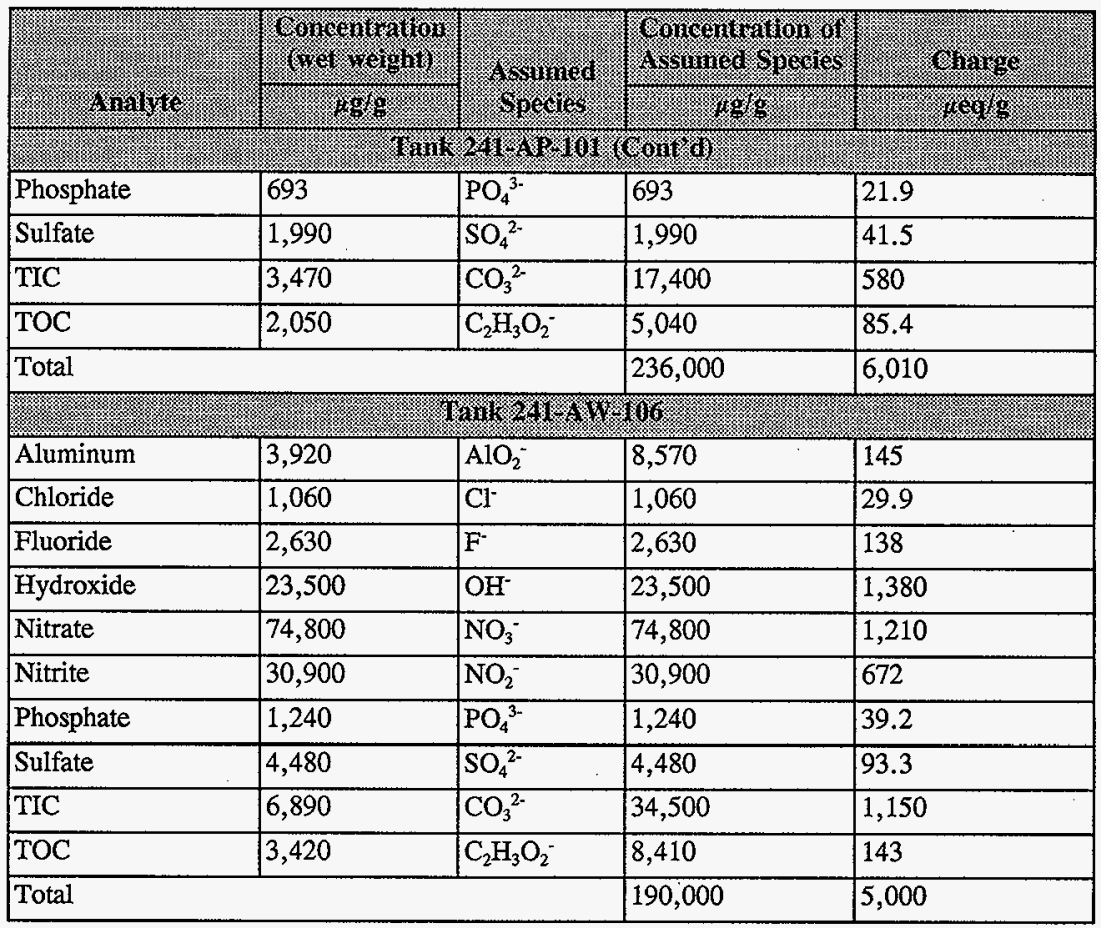

Table B3-5. Mass Balance Totals. (2 sheets)

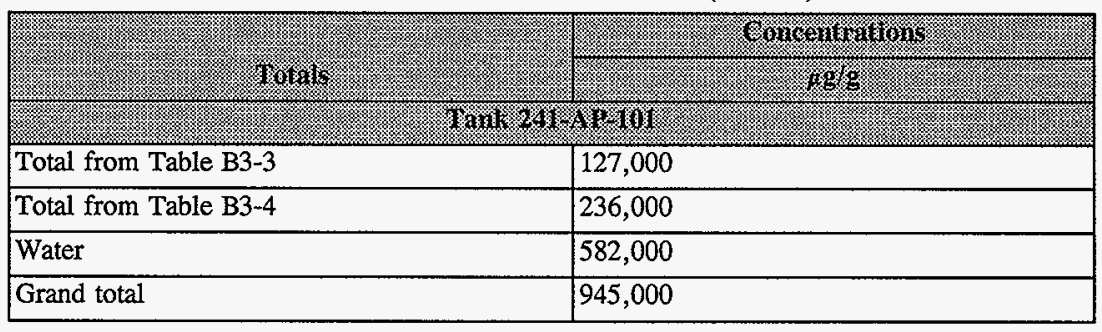




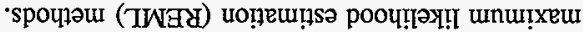

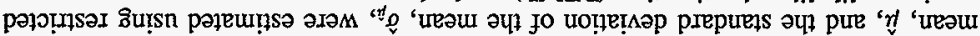

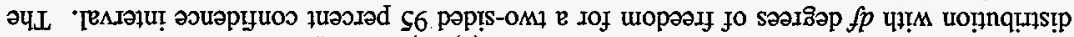

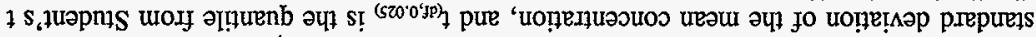

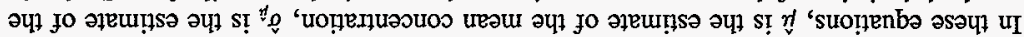

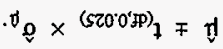

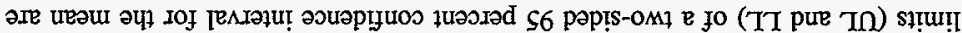

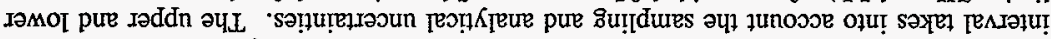

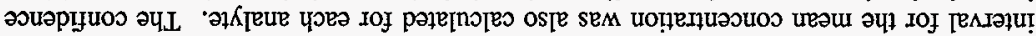

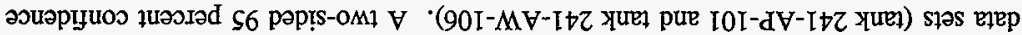

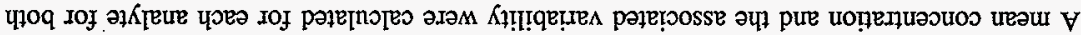

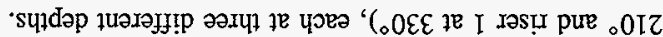

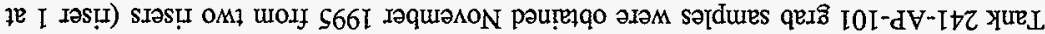
- ə[dures $\Lambda$ IInjS Iolejode

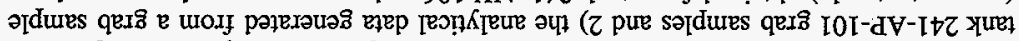

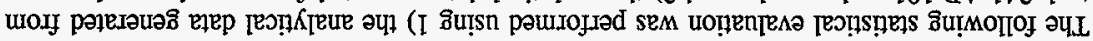

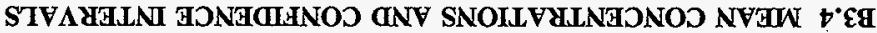

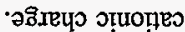

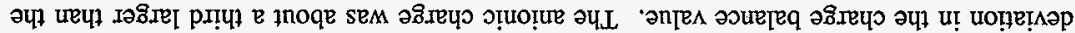

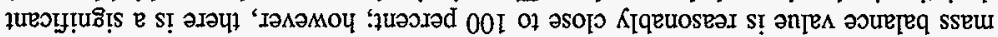

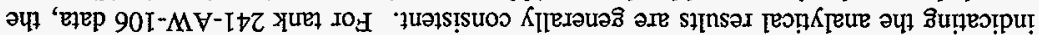

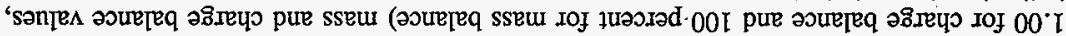

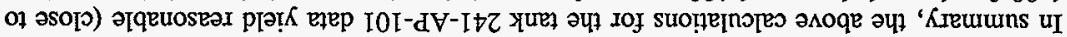

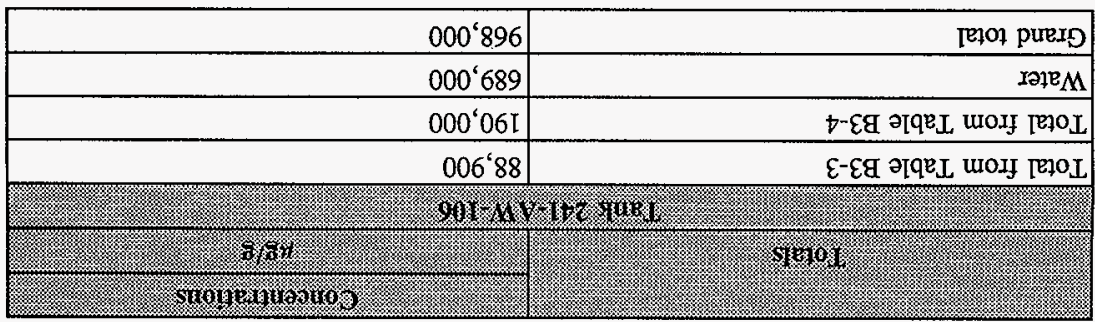

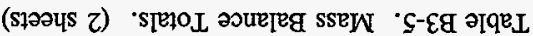




\section{B3.4.1 Mean Concentrations}

B3.4.1.1 Tank 241-AP-101 Data Set. The statistics for the first data set were based on analytical data from the November 1995 sampling event of tank 241-AP-101. The data were statistically evaluated using two models. The first model used a nested analysis of variance (ANOVA) where the data were identified by a grab sample within riser. The second model used one-way ANOVA where the data were identified by one variable (the grab sample). The ANOVA techniques were used to estimate the mean and its associated variability for all analytes that had at least 50 percent of the reported data as quantitative (or detected) values.

No ANOVA estimates were computed for analytes that had less than 50 percent of the reported data as quantitative values. For analytes having a mixture of quantitative values and "less-than" values, the ANOVA was computed using two methodologies.

- The upper value of the "less-than" (for example, 3.5 for $<3.5$ ) was used to represent all "less-than" analytical values in the first computation. This produces a bias of unknown magnitude in the mean analyte concentration and the variance associated with the mean; the mean analyte concentration is biased high. The extension ".w" was added to the analyte name in the tables to distinguish which analyte was statistically analyzed using "less-than" values.

- The "less-than" values were deleted in the second computation. Deleting data produces unbalanced data sets which complicates the statistical analysis and decreases the number of degrees of freedom. Deleting data also produces a bias of unknown magnitude in the mean analyte concentration and the variance associated with the mean. The extension ".wo" was added to the analyte name in the tables to distinguish which analyte was statistically analyzed with the "less-than" values deleted.

Table B3-6 shows the mean concentration estimates and the two-sided 95 percent confidence interval for the mean concentration (nested ANOVA) and Table B3-7 (one-way ANOVA) for analytes with at least 50 percent of the reported data as quantitative values. For some analytes, the lower limit of the 95 percent confidence interval was a negative value caused by the magnitude of the variability. Because the actual concentration of a tank sample cannot be less than zero, the lower limit is reported as zero. The analytes in Table B3-6 where $\hat{\sigma}_{\text {riser }}$ is not significantly different from zero are marked with a "*." The mean concentrations and the variances of the mean concentrations calculated using the two statistical models (one-way ANOVA and nested ANOVA) are not significantly different for these analytes.

Table B3-8 lists the analytes that had less than 50 percent of the reported data as quantitative values. Table B3-8 shows the largest value observed from the six analytical results. 
HNF-SD-WM-ER-357 Rev, 1

Table B3-6. Tank 241-AP-101 Summary Statistics Mean Concentrations (Nested Analysis of Variance).

\begin{tabular}{|c|c|c|c|c|c|c|}
\hline 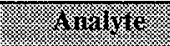 & Uorits & 2 & \% & 8 & (19. & (1) \\
\hline \%Water.tga ${ }^{3}$ & wt $\%$ & 58.2 & 0.770 & 1 & 48.5 & 68.0 \\
\hline Al.icp. $a^{1}$ & $\mu \mathrm{g} / \mathrm{mL}$ & 12,100 & 367 & 1 & 7,460 & 16,800 \\
\hline${ }^{241} \mathrm{Am} . \mathrm{w}$ & $\mu \mathrm{Ci} / \mathrm{mL}$ & $3.25 \mathrm{E}-04$ & $2.39 \mathrm{E}-05$ & 1 & $2.05 \mathrm{E}-05$ & $6.28 \mathrm{E}-04$ \\
\hline${ }^{241} \mathrm{Am} . \mathrm{wo}^{1}$ & $\mu \mathrm{Ci} / \mathrm{mL}$ & $3.04 \mathrm{E}-04$ & $3.69 \mathrm{E}-06$ & 1 & $2.57 \mathrm{E}-04$ & $3.50 \mathrm{E}-04$ \\
\hline $\mathrm{Cl}^{-} \cdot \mathrm{ic}^{1}$ & $\mu \mathrm{g} / \mathrm{mL}$ & 2,030 & 35.1 & 1 & 1,590 & 2,480 \\
\hline${ }^{137}$ Cs.gea ${ }^{1}$ & $\mu \mathrm{Ci} / \mathrm{mL}$ & 188 & 6.58 & 1 & 105 & 272 \\
\hline DSC.exo.dry ${ }^{1}$ & $\mathrm{~J} / \mathrm{g}$ dry & 65.0 & 58.4 & 1 & 0.00 & 807 \\
\hline DSC.exo.wet ${ }^{1}$ & $\mathrm{~J} / \mathrm{g}$ wet & 28.0 & 25.4 & 1 & 0.00 & 351 \\
\hline $\mathrm{F}^{-} \cdot \mathrm{ic}^{1}$ & $\mu \mathrm{g} / \mathrm{mL}$ & 2,080 & 318 & 1 & 0.00 & 6,120 \\
\hline $\mathrm{NO}_{2}^{-} \cdot \mathrm{ic}^{1}$ & $\mu \mathrm{g} / \mathrm{mL}$ & 41,700 & 1,120 & 1 & 27,400 & 56,000 \\
\hline $\mathrm{NO}_{3}^{-} \cdot \mathrm{ic}^{1}$ & $\mu \mathrm{g} / \mathrm{mL}$ & $1.54 \mathrm{E}+05$ & 5,660 & 1 & 82,200 & $2.26 \mathrm{E}+05$ \\
\hline Na.icp. $\mathrm{a}^{1}$ & $\mu \mathrm{g} / \mathrm{mL}$ & $1.66 \mathrm{E}+05$ & 4,170 & 1 & $1.12 \mathrm{E}+05$ & $2.18 \mathrm{E}+05$ \\
\hline $\mathrm{OH}^{-1}$ & $\mu \mathrm{g} / \mathrm{mL}$ & 49,400 & 1,570 & 1 & 29,400 & 69,400 \\
\hline $\mathrm{PO}_{4}^{3-} . \mathrm{ic} . \mathrm{w}^{1}$ & $\mu \mathrm{g} / \mathrm{mL}$ & 908 & 113 & 1 & 0.00 & 2,340 \\
\hline${ }^{239 / 240} \mathrm{Pu}^{1}$ & $\mu \mathrm{Ci} / \mathrm{mL}$ & $1.64 \mathrm{E}-04$ & $5.92 \mathrm{E}-06$ & 1 & $8.84 \mathrm{E}-05$ & $2.39 \mathrm{E}-04$ \\
\hline $\mathrm{SO}_{4}^{2} \cdot \mathrm{ic}^{1}$ & $\mu \mathrm{g} / \mathrm{mL}$ & 2,610 & 346 & 1 & 0.00 & 7,010 \\
\hline $\mathrm{SpG}^{1}$ & |-- & 1.31 & 0.0126 & 1 & 1.15 & 1.47 \\
\hline${ }^{89 / 90} \mathrm{Sr}^{1}$ & $\mu \mathrm{Ci} / \mathrm{mL}$ & 0.155 & 0.0125 & 1 & 0.00 & 0.314 \\
\hline TIC $^{\prime}$ & $\mu \mathrm{g} / \mathrm{mL}$ & 4,550 & 328 & 1 & 371 & 8,720 \\
\hline TOC & $\mu \mathrm{g} / \mathrm{mL}$ & 2,680 & 518 & 1 & 0.00 & 9,260 \\
\hline $\mathrm{pH}$ & unitless & 13.9 & 0.0467 & 1 & 13.3 & 14.5 \\
\hline
\end{tabular}

Note:

$1=\hat{\sigma}_{\text {riser }}$ is not significantly different from zero. 
Table B3-7. Tank 241-AP-101 Summary Statistics Mean Concentrations (One-Way Analysis of Variance).

\begin{tabular}{|c|c|c|c|c|c|c|}
\hline 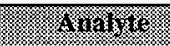 & (5inits. & (1) & (6) & (1) & 18 & (3) \\
\hline \%Water.tga & $w t \%$ & 58.2 & 0.770 & 5 & 56.3 & 60.2 \\
\hline Al.icp.a & $\mu \mathrm{g} / \mathrm{mL}$ & 12,100 & 362 & 5 & 11,200 & 13,000 \\
\hline${ }^{241}$ Am.wo & $\mu \mathrm{Ci} / \mathrm{mL}$ & 3.03E-04 & $2.97 \mathrm{E}-06$ & 4 & $2.95 \mathrm{E}-04$ & $3.11 \mathrm{E}-04$ \\
\hline $\mathrm{Cl}^{-} . \mathrm{ic}$ & $\mu \mathrm{g} / \mathrm{mL}$ & 2,030 & 35.1 & 5 & 1,940 & 2,120 \\
\hline${ }^{137}$ Cs.gea & $\mu \mathrm{Ci} / \mathrm{mL}$ & 188 & 6.58 & 5 & 171 & 205 \\
\hline DSC.exo.dry & $\mathrm{J} / \mathrm{g}$ dry & 65.0 & 58.4 & 5 & 0.00 & 215 \\
\hline DSC.exo.wet & J/g wet & 28.0 & 25.4 & 5 & 0.00 & 93.3 \\
\hline $\bar{F}$-ic & $\mu \mathrm{g} / \mathrm{mL}$ & 2,080 & 290 & 5 & 1,340 & 2,830 \\
\hline $\mathrm{NO}_{2}^{-}$.ic & $\mu \mathrm{g} / \mathrm{mL}$ & 41,700 & 1,120 & 5 & 38,800 & 44,600 \\
\hline $\mathrm{NO}_{3}^{-}$.ic & $\mu \mathrm{g} / \mathrm{mL}$ & $1.54 \mathrm{E}+05$ & 5,660 & 5 & $1.39 \mathrm{E}+05$ & $1.69 \mathrm{E}+05$ \\
\hline Na.icp.a & $\mu \mathrm{g} / \mathrm{mL}$ & $1.66 \mathrm{E}+05$ & 4,090 & 5 & $1.55 \mathrm{E}+05$ & $1.76 \mathrm{E}+05$ \\
\hline $\mathrm{OH}^{-}$ & $\mu \mathrm{g} / \mathrm{mL}$ & 49,400 & 1,570 & 5 & 45,400 & 53,500 \\
\hline $\mathrm{PO}_{4}^{3-}$. ic. $\mathrm{w}$ & $\mu \mathrm{g} / \mathrm{mL}$ & 908 & 113 & 5 & 619 & 1,200 \\
\hline $\mathrm{PO}_{4}^{3-}$.ic.wo & $\mu \mathrm{g} / \mathrm{mL}$ & 806 & 115 & 2 & 310 & 1,300 \\
\hline${ }^{239 / 240} \mathrm{Pu}$ & $\mu \mathrm{Ci} / \mathrm{mL}$ & $1.64 \mathrm{E}-04$ & $5.20 \mathrm{E}-06$ & 5 & $1.50 \mathrm{E}-04$ & $1.77 \mathrm{E}-04$ \\
\hline $\mathrm{SO}_{4}^{2-}$.ic & $\mu \mathrm{g} / \mathrm{mL}$ & 2,610 & 290 & 5 & 1,870 & 3,360 \\
\hline$\overline{\mathrm{SpG}}$ & -- & 1.31 & 0.0126 & 5 & 1.27 & 1.34 \\
\hline${ }^{89 / 90} \mathrm{Sr}$ & $\mu \mathrm{Ci} / \mathrm{mL}$ & 0.155 & 0.0125 & 5 & 0.123 & 0.187 \\
\hline TIC & $\mu \mathrm{g} / \mathrm{mL}$ & 4,550 & 279 & 5 & 3,830 & 5,260 \\
\hline
\end{tabular}

Table B3-8. Tank 241-AP-101 Analytes with >50 Percent "Less-Than" Values.

\begin{tabular}{|c|c|c|}
\hline 筑 & Slim & 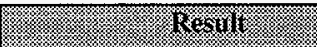 \\
\hline Total Alpha & $\mu \mathrm{Ci} / \mathrm{mL}$ & $<0.00341$ \\
\hline${ }^{60}$ Co.gea & $\mu \mathrm{Ci} / \mathrm{mL}$ & $<0.0443$ \\
\hline Fe.icp.a & $\mu \mathrm{g} / \mathrm{mL}$ & $<20$ \\
\hline
\end{tabular}


B.3.4.1.2 Tank 241-AW-106 Grab Sample, Evaporator Slurry Sample. The statistics for the second data set were based on analytical data from two 1995 sampling events: one grab sample (supernatant) from tank 241-AW-106 and one evaporator slurry sample (from Campaign 95-1). If duplicate analyses were performed, the data were statistically evaluated using one-way ANOVA. For the analytes without duplicate analyses, the mean and the standard deviation of the mean were calculated. The less-than values were treated the same way as for the first data set.

Table B3-9 gives mean concentration estimates and the two-sided 95 percent confidence interval for the mean concentration. For some analytes, the lower limit of the 95 percent confidence interval was a negative value caused nu the magnitude of the variability. Because the actual concentration of a tank sample cannot be less than zero, the lower limit is reported as zero. Table B3-10 lists the analytes that had 50 percent or less of the reported data as quantitative values. Table B3-10 also cites the largest value observed from the two (occasionally three) analytical results.

Table B3-9. Tank 241-AW-106 Summary Statistics - Mean Concentrations. (2 sheets)

\begin{tabular}{|c|c|c|c|c|c|c|}
\hline 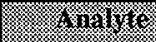 & Wins & t) & ( & or & 16 & 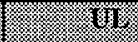 \\
\hline $\mathrm{Al}$ & $\mu \mathrm{g} / \mathrm{mL}$ & 4,940 & 350 & 1 & 493 & 9,390 \\
\hline $\mathrm{OH}^{-}$ & $\mu \mathrm{g} / \mathrm{mL}$ & 29,600 & 1,900 & 1 & 5,450 & 53,700 \\
\hline$\overline{S p G}$ & -- & 1.26 & 0.0470 & 1 & 0.665 & 1.86 \\
\hline $\mathrm{TC}$ & $\mu \mathrm{g} / \mathrm{mL}$ & 20,000 & 7,420 & 1 & 0.00 & $1.14 \mathrm{E}+05$ \\
\hline TIC & $\mu \mathrm{g} / \mathrm{mL}$ & 8,680 & 380 & 1 & 3,850 & 13,500 \\
\hline TOC & $\mu \mathrm{g} / \mathrm{mL}$ & 4,310 & 992 & 1 & 0.00 & 16,900 \\
\hline $\mathrm{pH}$ & unitless & 13.8 & 0.337 & 1 & 9.55 & 18.1 \\
\hline${ }^{14} \mathrm{C}$ & $\mu \mathrm{Ci} / \mathrm{mL}$ & $1.55 \mathrm{E}-04$ & $1.95 \mathrm{E}-05$ & 1 & 0.00 & $4.02 \mathrm{E}-04$ \\
\hline${ }^{134} \mathrm{Cs}$ & $\mu \mathrm{Ci} / \mathrm{mL}$ & 0.266 & 0.0420 & 1 & 0.00 & 0.800 \\
\hline${ }^{137} \mathrm{Cs}$ & $\mu \mathrm{Ci} / \mathrm{mL}$ & 127 & 15.0 & 1 & 0.00 & 318 \\
\hline $\mathrm{F}^{-}$ & $\mu \mathrm{g} / \mathrm{mL}$ & 3,310 & 565 & 1 & 0.00 & 10,500 \\
\hline $\mathrm{Na}$ & $\mu \mathrm{g} / \mathrm{mL}$ & $1.12 \mathrm{E}+05$ & 8,500 & 1 & 3,500 & $2.20 \mathrm{E}+05$ \\
\hline $\mathrm{NO}_{2}^{-}$ & $\mu \mathrm{g} / \mathrm{mL}$ & 38,900 & 1,600 & 1 & 18,600 & 59,200 \\
\hline $\mathrm{NO}_{3}^{-}$ & $\mu \mathrm{g} / \mathrm{mL}$ & 94,200 & 1,300 & 1 & 77,700 & $1.11 \mathrm{E}+05$ \\
\hline $\mathrm{PO}_{4}^{3-}$ & $\mu \mathrm{g} / \mathrm{mL}$ & 1,560 & 370 & 1 & 0.00 & 6,260 \\
\hline${ }^{239 / 240} \mathrm{Pu}$ & $\mu \mathrm{Ci} / \mathrm{mL}$ & $2.18 \mathrm{E}-04$ & $8.00 \mathrm{E}-05$ & 1 & 0.00 & 0.00123 \\
\hline $\mathrm{SO}_{4}^{2-}$ & $\mu \mathrm{g} / \mathrm{mL}$ & 5,650 & 135 & 1 & 3,930 & 7,360 \\
\hline${ }^{79} \mathrm{Se}$ & $\mu \mathrm{Ci} / \mathrm{mL}$ & $1.05 \mathrm{E}-04$ & $1.70 \mathrm{E}-05$ & 1 & 0.00 & $3.20 \mathrm{E}-04$ \\
\hline
\end{tabular}


HNF-SD-WM-ER-357 Rev. 1

Table B3-9. Tank 241-AW-106 Summary Statistics - Mean Concentrations. (2 sheets)

\begin{tabular}{|c|c|c|c|c|c|c|}
\hline 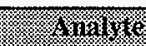 & Sinim & (3) & (N) & (1) & 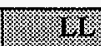 & (1) \\
\hline${ }^{89 / 90} \mathrm{Sr}$ & $\mu \mathrm{Ci} / \mathrm{mL}$ & 0.0990 & 0.0651 & 1 & 0.00 & 0.925 \\
\hline${ }^{99} \mathrm{Tc}$ & $\mu \mathrm{Ci} / \mathrm{mL}$ & 0.0322 & 0.00305 & 1 & 0.00 & 0.0709 \\
\hline Total beta & $\mu \mathrm{Ci} / \mathrm{mL}$ & 119 & 24.6 & 1 & 0.00 & 432 \\
\hline${ }^{3} \mathrm{H}$ & $\mu \mathrm{Ci} / \mathrm{mL}$ & 0.00850 & 0.00280 & 1 & 0.00 & 0.0441 \\
\hline$\overline{\mathbf{U}}$ & $\mu \mathrm{g} / \mathrm{mL}$ & 69.2 & 1.95 & 1 & 44.4 & 93.9 \\
\hline \multicolumn{7}{|c|}{ 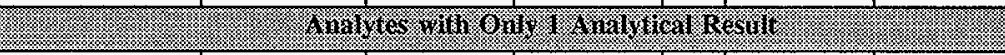 } \\
\hline $\mathrm{Cl}^{-}$ & $\mu \mathrm{g} / \mathrm{mL}$ & 1,340 & $\mathrm{n} / \mathrm{a}$ & $n / a$ & $n / a$ & $n / a$ \\
\hline DSC & $\mathrm{J} / \mathrm{g}$ dry & 0.00 & $\mathrm{n} / \mathrm{a}$ & $n / a$ & $\mathrm{n} / \mathrm{a}$ & $\mathrm{n} / \mathrm{a}$ \\
\hline $\mathrm{NH}_{3}$ & $\mu \mathrm{g} / \mathrm{mL}$ & 2.94 & $\mathrm{n} / \mathrm{a}$ & $n / a$ & $n / a$ & $n / a$ \\
\hline \%Water & wt\% & 68.9 & $\mathrm{n} / \mathrm{a}$ & $n / a$ & $n / a$ & $n / a$ \\
\hline
\end{tabular}

Table B3-10. Tank 241-AW-106 Analytes with $\geq 50$ Percent "Less-Than" Values.

\begin{tabular}{|l|l|l|}
\hline \multicolumn{1}{|c|}{} & \multicolumn{1}{c}{ (1) } & $<0.00109$ \\
\hline${ }^{241} \mathrm{Am}$ & $\mu \mathrm{Ci} / \mathrm{mL}$ & $<0.351$ \\
\hline${ }^{144} \mathrm{Ce} / \mathrm{Pr}$ & $\mu \mathrm{Ci} / \mathrm{mL}$ & $<0.0184$ \\
\hline${ }^{60} \mathrm{Co}$ & $\mu \mathrm{Ci} / \mathrm{mL}$ & $<0.00109$ \\
\hline${ }^{243 / 244} \mathrm{Cm}$ & $\mu \mathrm{Ci} / \mathrm{mL}$ & $<0.0446$ \\
\hline${ }^{154} \mathrm{Eu}$ & $\mu \mathrm{Ci} / \mathrm{mL}$ & $<0.158$ \\
\hline${ }^{155} \mathrm{Fu}$ & $\mu \mathrm{g} / \mathrm{mL}$ & $<20.05$ \\
\hline${ }^{129} \mathrm{I}$ & $\mu \mathrm{Ci} / \mathrm{mL}$ & $<5.76 \mathrm{E}-05$ \\
\hline${ }^{94} \mathrm{Nb}$ & $\mu \mathrm{Ci} / \mathrm{mL}$ & $<0.0157$ \\
\hline${ }^{237} \mathrm{~Np}$ & $\mu \mathrm{Ci} / \mathrm{mL}$ & $<2.06 \mathrm{E}-05$ \\
\hline${ }^{238} \mathrm{Pu}$ & $\mu \mathrm{Ci} / \mathrm{mL}$ & $<8.57 \mathrm{E}-05$ \\
\hline${ }^{226} \mathrm{Ra}$ & $\mu \mathrm{Ci} / \mathrm{mL}$ & $<1.48$ \\
\hline${ }^{106} \mathrm{Ru} / \mathrm{Rh}$ & $\mu \mathrm{Ci} / \mathrm{mL}$ & $<1.17$ \\
\hline $\mathrm{Total}$ alpha & $\mu \mathrm{Ci} / \mathrm{mL}$ & $<0.0134$ \\
\hline
\end{tabular}




\section{B3.4.2 Analysis of Variance Model}

A statistical model is needed to account for the spatial and measurement variability in $\hat{\sigma}_{\hat{\hat{\mu}}}$. This cannot be done using an ordinary standard deviation of the data (Snedecor and Cochran 1980).

The data were statistically evaluated using two models. The first model used a nested analysis of variance. The nested analysis of variance statistical model used to describe the structure of the data is:

$$
\begin{gathered}
Y_{i j k}=\mu+R_{i}+S_{i j}+A_{i j k}, \\
i=1,2, \ldots, a ; j=1,2, \ldots, b_{i} ; k=1,2, \ldots, n_{i j} ;
\end{gathered}
$$

where

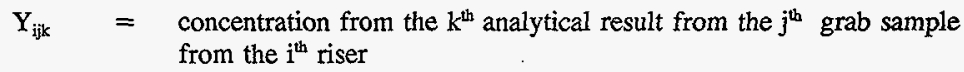

$$
\begin{aligned}
& \mu \quad=\quad \text { the grand mean } \\
& \mathbf{R}_{\mathrm{i}} \quad=\text { the effect of the } \mathrm{i}^{\text {th }} \text { riser } \\
& S_{i j}=\text { the effect of the } j^{\text {th }} \text { grab sample from the } i^{\text {th }} \text { riser } \\
& A_{i j k}=\text { the effect of the } k^{\text {th }} \text { analytical result from the } j^{\text {th }} \text { grab sample from the } \mathrm{i}^{\text {th }} \\
& \text { riser } \\
& \text { a } \quad=\text { the number of risers } \\
& b_{i}=\text { the number of grab samples from the } i^{\text {it }} \text { riser } \\
& \mathrm{n}_{\mathrm{ij}}=\text { the number of analytical results from the } \mathrm{j}^{\mathrm{th}} \text { grab sample from the } \mathrm{i}^{\text {th }}
\end{aligned}
$$

The variables $R_{i}$ and $S_{i j}$ are assumed to be random effects. These variables and $A_{i j k}$ are assumed to be uncorrelated and normally distributed with means zero and variances $\sigma^{2}(R)$, $\sigma^{2}(\mathrm{~S})$, and $\sigma^{2}(\mathrm{~A})$, respectively. Estimates of $\sigma^{2}(\mathrm{R}), \sigma^{2}(\mathrm{~S})$, and $\sigma^{2}(\mathrm{~A})$ were obtained using REML techniques. This method applied to variance component estimation is described in Harville (1977). The results using the REML techniques were obtained using the statistical 
analysis package S-PLUS ${ }^{3}$ (Statistical Sciences 1993). The $d f$ associated with the standard deviation of the mean (a function of $\sigma^{2}(\mathrm{R}), \sigma^{2}(\mathrm{~S})$, and $\sigma^{2}(\mathrm{~A})$ ) is the number of risers minus one.

The second model used one-way analysis of variance. The one-way analysis of variance statistical model used to describe the structure of the data is:

$$
\begin{gathered}
Y_{i j}=\mu+S_{i}+A_{i j}, \\
i=1,2, \ldots, a ; j=1,2, \ldots, n_{i} ;
\end{gathered}
$$

where

$$
\begin{aligned}
& \mathrm{Y}_{\mathrm{ij}} \quad=\text { concentration from the } \mathrm{j}^{\text {th }} \text { analytical result from the } \mathrm{i}^{\mathrm{th}} \text { grab sample } \\
& \mu \quad=\text { the grand mean } \\
& \mathrm{S}_{\mathrm{i}} \quad=\text { the effect of the } \mathrm{i}^{\mathrm{ith}} \text { grab sample } \\
& \mathrm{A}_{\mathrm{ij}} \quad=\quad \text { the effect of the } \mathrm{j}^{\mathrm{th}} \text { analytical result from the } \mathrm{i}^{\text {th }} \text { grab sample } \\
& \mathrm{a} \quad=\quad \text { the number of grab samples } \\
& \mathrm{n}_{\mathrm{i}} \quad=\quad \text { the number of analytical results from the } \mathrm{i}^{\mathrm{ih}} \text { grab sample. }
\end{aligned}
$$

The variable $S_{i}$ is assumed to be a random effect. This variable and $A_{i j}$ are assumed to be uncorrelated and normally distributed with means zero and variances $\sigma^{2}(\mathbf{S})$ and $\sigma^{2}(\mathrm{~A})$, respectively. Estimates of $\sigma^{2}(\mathrm{~S})$ and $\sigma^{2}(\mathrm{~A})$ were obtained using REML techniques. This method applied to variance component estimation is described in Harville (1977). The results using the REML techniques were obtained using the statistical analysis package S-PLUS (Statistical Sciences 1993). The $d f$ associated with the standard deviation of the mean (a function of $\sigma^{2}(\mathrm{~S})$ and $\sigma^{2}(\mathrm{~A})$ ) is the number of grab samples minus one.

\section{B3.4.3 Sampling Based Tank Inventory}

The sampling based tank inventory for each analyte is calculated by multiplying the tank volume for liquids by the mean concentration. The liquid tank volume for tank 241-AP-101 at the time it was sampled in November 1995 was $2,790 \mathrm{~kL}$ (737 kgal). After the

\footnotetext{
${ }^{3}$ S-PLUS is a registered trademark of Statistical Science, Seattle, WA.
} 
November 1995 sampling event, $1,160 \mathrm{~kL}$ (306 kgal) of liquid waste from tank 241-AW-106 was transferred to tank 241-AP-101. The sampling based tank inventory was calculated using

$$
T k \operatorname{Inv}=a X+b Y
$$

where $\mathrm{a}$ is the volume for tank 241-AP-101, $\mathrm{X}$ is the mean concentration for tank 241-AP-101 (nested ANOVA model), $b$ is the volume for the waste transferred from tank 241-AW-106, and $\mathrm{Y}$ is the mean concentration for tank 241-AW-106.

The variance for the sampling based tank inventory was calculated using

$$
\operatorname{Var}(T k \text { Inv })=a^{2} \operatorname{Var}(X)+b^{2} \operatorname{Var}(Y)
$$

where $\mathrm{a}, \mathrm{b}, \mathrm{X}$, and $\mathrm{Y}$ are defined as above.

The lower and upper limits for the sampling based tank inventory were calculated using

$$
\text { Tk Inv } \pm t_{(1,0.025)} \times \operatorname{Std}(T k \text { Inv) }
$$

where Std(Tk Inv) is the square root of Var(Tk Inv).

The degrees of freedom associated with the variance of tank 241-AP-101 data were used in determining the lower and upper limits for tank inventory. Table B3-11 shows the tank inventory and upper and lower limits for analytes having concentration data for tanks 241-AP-101 and 241-AW-106.

For analytes with less than 50 percent of the data reported as quantitative values, the tank inventory was calculated by multiplying the tank volume by the concentration listed in Tables B3-8 and B3-10. Values for the lower limit and the upper limit are not possible. 
Table B3-11. Analytical-Based Inventory for

Tank 241-AP-101.

\begin{tabular}{|c|c|c|c|}
\hline 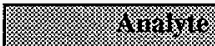 & & 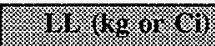 & 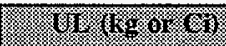 \\
\hline \% Water ${ }^{2}$ & $3.40 \mathrm{E}+06 \mathrm{~kg}$ & $3.15 E+06$ & $3.64 \mathrm{E}+06$ \\
\hline $\mathrm{Al}$ & $4.09 \mathrm{E}+04 \mathrm{~kg}$ & $2.64 \mathrm{E}+04$ & $5.54 \mathrm{E}+04$ \\
\hline${ }^{241} \mathrm{Am} \cdot \mathrm{w}^{2}$ & $<2.47 \mathrm{E}+00 \mathrm{Ci}$ & $7.77 \mathrm{E}-01$ & $4.17 \mathrm{E}+00$ \\
\hline $241 \mathrm{Am} \cdot \mathrm{wo}^{2}$ & $<2.41 \mathrm{E}+00 \mathrm{Ci}$ & $2.14 \mathrm{E}+00$ & $2.69 \mathrm{E}+00$ \\
\hline $\mathrm{Cl} \cdot \mathrm{ic}^{2}$ & $7.59 \mathrm{E}+03 \mathrm{~kg}$ & $6.28 \mathrm{E}+03$ & $8.91 \mathrm{E}+03$ \\
\hline${ }^{137}$ Cs.gea & $7.08 \mathrm{E}+05 \mathrm{Ci}$ & $3.48 \mathrm{E}+05$ & $1.07 \mathrm{E}+06$ \\
\hline $\bar{F}$.ic & $1.06 \mathrm{E}+04 \mathrm{~kg}$ & $0.00 \mathrm{E}+00$ & $2.58 \mathrm{E}+04$ \\
\hline $\mathrm{NO}_{2}^{-}$.ic & $1.72 \mathrm{E}+05 \mathrm{~kg}$ & $1.23 \mathrm{E}+05$ & $2.22 \mathrm{E}+05$ \\
\hline $\mathrm{NO}_{3}^{-} \cdot \mathrm{ic}$ & $5.65 \mathrm{E}+05 \mathrm{~kg}$ & $3.63 \mathrm{E}+05$ & $7.67 \mathrm{E}+05$ \\
\hline Na.icp.a & $6.22 \mathrm{E}+05 \mathrm{~kg}$ & $4.07 \mathrm{E}+05$ & $8.36 \mathrm{E}+05$ \\
\hline $\mathrm{OH}^{-}$ & $1.80 \mathrm{E}+05 \mathrm{~kg}$ & $1.15 \mathrm{E}+05$ & $2.46 \mathrm{E}+05$ \\
\hline $\mathrm{PO}_{4}^{3-}$.ic.w & $4.78 \mathrm{E}+03 \mathrm{~kg}$ & $0.00 \mathrm{E}+00$ & $1.26 \mathrm{E}+04$ \\
\hline $239 / 240 \mathrm{Pu}$ & $7.70 \mathrm{E}-01 \mathrm{Ci}$ & $0.00 \mathrm{E}+00$ & $2.25 \mathrm{E}+00$ \\
\hline $\mathrm{SO}_{4}^{2-}$.ic & $1.54 \mathrm{E}+04 \mathrm{~kg}$ & $2.89 \mathrm{E}+03$ & $2.79 \mathrm{E}+04$ \\
\hline${ }^{89 / 190} \mathrm{Sr}$ & $5.76 \mathrm{E}+02 \mathrm{~kg}$ & $0.00 \mathrm{E}+00$ & $1.84 \mathrm{E}+03$ \\
\hline TIC & $2.52 \mathrm{E}+04 \mathrm{~kg}$ & $1.16 \mathrm{E}+04$ & $3.87 \mathrm{E}+04$ \\
\hline TOC & $1.37 \mathrm{E}+04 \mathrm{~kg}$ & $0.00 \mathrm{E}+00$ & $3.95 \mathrm{E}+04$ \\
\hline Total alpha & $<2.88 \mathrm{E}+01 \quad \mathrm{Ci}$ & $n / a$ & $n / a$ \\
\hline${ }^{60} \mathrm{Co}$.gea & $<1.50 \mathrm{E}+02 \mathrm{Ci}$ & $\mathrm{n} / \mathrm{a}$ & $n / a$ \\
\hline Fe.icp.a & $<8.46 \mathrm{E}+01 \mathrm{~kg}$ & $n / a$ & $n / a$ \\
\hline
\end{tabular}

Notes:

${ }^{1}$ The mean concentrations and the associated variabilities listed in Table B3- 6 and Table 3-8 were used for the first data set (tank 241-AP-101). The mean concentrations and the associated variabilities listed in Tables B3-9 and B3-10 were used for the second data set (tank 241-AW-106 grab sample and the evaporator slurry sample).

${ }^{2}$ The variability associated with the tank 241-AP-101 data was used to estimate the variability associated with the tank $241-\mathrm{AW}-106$ data. 


\section{B4.0 APPENDIX B REFERENCES}

Bratzel, D. R., 1994, "Letter of Instruction for Tank 241-AP-101 Grab Samples," (internal memorandum 7E720-94-145 to J. G. Kristofzski, December 12), Westinghouse Hanford Company, Richland, Washington.

Bushaw, T. H., 1996, "AP-101 DSC Anomaly," (internal memorandum 75763-96-002 to J. G. Kristofzski, January 26), Westinghouse Hanford Company, Richland, Washington.

DeLorenzo, D. S., A. T. DiCenso, D. B. Hiller, K. W. Johnson, J. H. Rutherford, and D. J. Smith, 1994, Tank Characterization Reference Guide, WHC-SD-WM-TI-648, Rev. 0, Westinghouse Hanford Company, Richland, Washington.

DiCenso, A. T., D. S. De Lorenzo, L. C. Amato, J. D. Franklin, R. W. Lambie, and B. C. Simpson, 1994, Tank Characterization Report for Double-Shell Tank 241-AP-101, WHC-SD-WM-ER-357, Rev. 0, Westinghouse Hanford Company, Richland, Washington.

Dukelow, G. T., J. W. Hunt, H. Babad, and J. E. Meacham, 1995, Tank Safety Screening Data Quality Objective, WHC-SD-WM-SP-004, Rev. 2, Westinghouse Hanford Company, Richland, Washington.

Esch, R. A., 1995a, 60-Day Waste Compatibility Safety Issue and Final Results for Tank 241-AW-106, Grab Samples 6AW-95-1, 6AW-95-2, and 6AW-95-3, WHC-SD-WM-DP-147, Rev. 0, Westinghouse Hanford Company, Richland, Washington.

Esch, R. A., 1995b, Tank 241-AP-101 Grab Sampling and Analysis Plan, WHC-SD-WM-TSAP-062, Rev. 0A, Westinghouse Hanford Company, Richland, Washington.

Esch, R. A., 1996, Final Report for Tank 241-AP-101, Grab Samples 2AP-95-1, 2AP-95-2, 2AP-95-3, 2AP-95-4, 2AP-95-5, and 2AP-95-6, WHC-SD-WM-DP-161, Rev. 1 , Westinghouse Hanford Company, Richland, Washington.

Fowler, K. D., 1995, Data Quality Objectives for Tank Farms Waste Compatibility Program, WHC-SD-WM-DQO-001, Rev. 1, Westinghouse Hanford Company, Richland, Washington.

Guthrie, M. D., 1996, 242-A Campaign 95-1 Post Run Document, WHC-SD-WM-PE-055, Rev. 0, Westinghouse Hanford Company, Richland, Washington. 
Harville, D. A., 1977, "Maximum Likelihood Approaches to Variance Component Estimation and to Related Problems," Journal of the American Statistical Association, pp. $320-340$.

Jones, J. M., 1995, Compatibility Grab Sampling and Analysis Plan, WHC-SD-WM-TSAP-037, Rev. 1A, Westinghouse Hanford Company, Richland, Washington.

Le, E. Q., 1995, 242-A Evaporator Sample Schedule for Campaign 95-1, FSS-T-630-00001, Rev. B5, Westinghouse Hanford Company, Richland, Washington.

Miller, G. L., 1993, 222-S Validation Summary for Double-Shell Tank 241-AP-101, WHC-SD-WM-DP-051, Rev. 0, Westinghouse Hanford Company, Richland, Washington.

NFPA, 1995, National Fire Codes, Vol. 10, Section 115, "Laser Fire Protection," National Fire Protection Association, Quincy, Massachusetts.

Rollison, M. D., 1995a, "Results for 241-AP-101 Grab Samples," (internal memorandum 8E480-95-022 to J. M. Jones, April 10), Westinghouse Hanford Company, Richland, Washington.

Rollison, M. D., 1995b, "Results for Tank 241-AP-101," (internal memorandum 8E480-95-001 to J. M. Jones, January 19), Westinghouse Hanford Company, Richland, Washington.

Schreiber, R. D., 1995, "Letter of Instruction for Tank 241-AP-101 Grab Samples," (internal memorandum 71520-95-107 to A. D. Rice, March 13), Westinghouse Hanford Company, Richland, Washington.

Snedecor, G. W., and W. G. Cochran, 1980, Statistical Methods, 7th Edition, Iowa State University Press, Ames, Iowa.

Statistical Sciences, 1993, S-PLUS Reference Manual, Version 3.2, StatSci (a division of MathSoft, Inc.), Statistical Sciences, Inc., Seattle, Washington.

WHC 1996, Safery Department Administrative Manual, WHC-IP-0030, Westinghouse Hanford Company, Richland, Washington. 
HNF-SD-WM-ER-357 Rev. 1

APPENDIX C

STATISTICS FOR SAFETY SCREENING DATA QUALITY OBJECTIVE

C-1 
HNF-SD-WM-ER-357 Rev. 1

This page intentionally left blank.

C-2 


\section{APPENDIX C \\ STATISTICS FOR SAFETY SCREENING DATA QUALITY OBJECTIVE}

\section{C1.0 STATISTICAL ANALYSIS: CONFIDENCE LEVELS}

The safety screening DQO (Dukelow et al. 1995) defines acceptable decision confidence limits in terms of one-sided 95 percent confidence intervals. In this appendix, the results of computing one-sided confidence limits are reported for tank 241-AP-101. The data are from the November 1995 sampling event for tank 241-AP-101, the 1995 sampling event for tank 241-AW-106, and the evaporator slurry sample.

Confidence intervals were computed for each grab sample using the analytical data. The UL of a one-sided 95 percent confidence interval for the mean is

$$
\hat{\mu}+\mathrm{t}_{(\mathrm{df}, 0.05)} * \hat{\sigma}_{\hat{\mu}} .
$$

In this equation, $\hat{\mu}$ is the arithmetic mean of the data, $\hat{\sigma}_{\hat{\mu}}$ is the estimate of the standard deviation of the mean, and $\mathbf{t}_{(\mathbf{d f}, 0.05)}$ is the quantile from Student's $t$ distribution with $d f$ degrees of freedom for a one-sided 95 percent confidence interval. For these grab samples (per sample number), $d f$ equals the number of observations minus one.

Table C1-1 lists the upper limit of the 95 percent confidence interval for each sample number based on the exothermic DSC results (dry weight). Each confidence interval can be used to make the following statement. If the upper limit of the exotherm for the sample is less than $480 \mathrm{~J} / \mathrm{g}$ (dry basis), reject the null hypothesis that exotherm is greater than or equal to $480 \mathrm{~J} / \mathrm{g}$ dry at the 0.05 level of significance. For seven of eight grab samples, the upper limit is less than $480 \mathrm{~J} / \mathrm{g}$ on a dry weight basis. The upper limit for sample S95T003730 (four analytical results of $0,877,0,0$ ) is greater than $480 \mathrm{~J} / \mathrm{g}$ on a dry basis. However, if one result is considered to be an outlier and is deleted from the statistical analysis, the upper limit is not greater than $480 \mathrm{~J} / \mathrm{g}$ dry. Therefore, the hypothesis that DSC results are greater than $480 \mathrm{~J} / \mathrm{g}$ dry is rejected for seven of eight grab samples. The hypothesis that DSC results are greater than $480 \mathrm{~J} / \mathrm{g}$ dry is rejected for the eighth sample if one analytical result is declared an outlier, as was concluded in Section 2.1.1. Therefore, the confidence interval is below the safety action limit for all valid samples.

Because all analytical results for total alpha were less-than values, confidence intervals are not possible. The largest nondetect value was $<0.00341 \mu \mathrm{Ci} / \mathrm{mL}$ which is less than the total alpha limit of $61.5 \mu \mathrm{Ci} / \mathrm{mL}$. Table $\mathrm{C} 1-2$ lists the data. The ${ }^{239 / 240} \mathrm{Pu}$ data were used to evaluate the plutonium limit of $1 \mathrm{~g} / \mathrm{L}$. The ${ }^{239 / 240} \mathrm{Pu}$ data were transformed to $\mathrm{g} / \mathrm{L}$ by assuming that all the plutonium is ${ }^{239} \mathrm{Pu}$ and using the specific activity of $0.062 \mathrm{Ci} / \mathrm{g}$ to convert from curies to grams. Table C1-3 lists the sample numbers and the upper limit of 
the 95 percent confidence intervals. Each confidence interval can be used to make the following statement. If the upper limit is less than $1 \mathrm{~g} / \mathrm{L}$, reject the null hypothesis that the ${ }^{239 / 240} \mathrm{Pu}$ is greater than or equal to $1 \mathrm{~g} / \mathrm{L}$ at the 0.05 level of significance. The upper limit was less than $1 \mathrm{~g} / \mathrm{L}$ for six of eight grab samples. Thus, the hypothesis that the plutonium results are greater than $1 \mathrm{~g} / \mathrm{L}$ is rejected for six of eight grab samples. An upper limit is not possible for the remaining two grab samples because duplicate analyses were not performed. However, the Pu concentrations $(\mathrm{g} / \mathrm{L})$ are orders of magnitude below the limit $(1 \mathrm{~g} / \mathrm{L})$.

Table C1-1. Summary Statistics - Differential Scanning Calorimetry.

\begin{tabular}{|c|c|c|c|c|}
\hline Sanong: & Granire & ( & 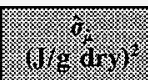 & (1) \\
\hline S95T003721 & $\begin{array}{l}\text { Tank } 241-\mathrm{AP}-101, \\
\text { riser } 1 \text { at } 210^{\circ}, 516 \\
\text { in. elevation }\end{array}$ & 0.00 & 0.00 & 0.00 \\
\hline S95T003722 & $\begin{array}{l}\text { Tank } 241-\mathrm{AP}-101, \\
\text { riser } 1 \text { at } 210^{\circ}, \\
383 \text { in. elevation }\end{array}$ & 0.00 & 0.00 & 0.00 \\
\hline S95T003723 & $\begin{array}{l}\text { Tank } 241-\mathrm{AP}-101, \\
\text { riser } 1 \text { at } 210^{\circ}, \\
640 \text { in. elevation }\end{array}$ & 0.00 & 0.00 & 0.00 \\
\hline S95T003728 & $\begin{array}{l}\text { Tank } 241-\mathrm{AP}-101 \text {, } \\
\text { riser } 1 \text { at } 330^{\circ} \text {, } \\
383 \text { in. elevation }\end{array}$ & 48.7 & 48.7 & 356 \\
\hline S95T003729 & $\begin{array}{l}\text { Tank } 241-\mathrm{AP}-101, \\
\text { riser } 1 \text { at } 330^{\circ}, \\
516 \text { in. elevation }\end{array}$ & 0.00 & 0.00 & 0.00 \\
\hline S95T003730 & $\begin{array}{l}\text { Tank } 241-\mathrm{AP}-101, \\
\text { riser } 1 \text { at } 330^{\circ}, \\
640 \text { in. elevation }\end{array}$ & $\begin{array}{l}175 \\
0.00^{1}\end{array}$ & \begin{tabular}{|l|}
175 \\
$0.00^{1}$
\end{tabular} & \begin{tabular}{|l|}
549 \\
$0.00^{1}$
\end{tabular} \\
\hline S95T002016 & $\begin{array}{l}\text { Tank 241-AW-106 } \\
\text { riser 16B, } \\
6 \mathrm{AW}-95-1\end{array}$ & 0.00 & 0.00 & 0.00 \\
\hline $\mathrm{T} 2270$ & $\begin{array}{l}\text { Evaporator slurry } \\
\text { sample }\end{array}$ & 0.00 & 0.00 & 0.00 \\
\hline
\end{tabular}

Note:

${ }^{1}$ Outlier deleted. 


\begin{tabular}{|c|c|c|}
\hline $66200^{\circ} 0>$ & วldues Kinns IoleIodeng & $0 L Z Z L$ \\
\hline$\downarrow \varepsilon I 0^{\circ} 0>$ & 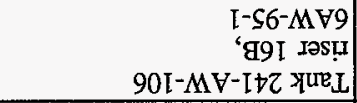 & 9I0Z00LS6S \\
\hline $\begin{array}{l}\angle 8200^{\circ} 0> \\
\angle 8200^{\circ} 0>\end{array}$ & 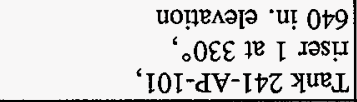 & LELE00LS6S \\
\hline $\begin{array}{l}9 \$ 200^{\circ} 0> \\
\$ Z 200^{\circ} 0>\end{array}$ & 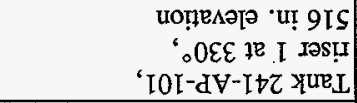 & $9 \varepsilon L \varepsilon 00 L S 6 S$ \\
\hline $\begin{array}{l}9 \varsigma 200^{\circ} 0> \\
9 \$ 200^{\circ} 0>\end{array}$ & 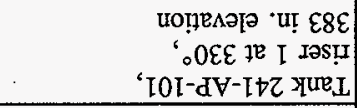 & SELE00LS6S \\
\hline $\begin{array}{l}68100^{\circ} 0> \\
{\left[t \varepsilon 00^{\circ} 0>\right.}\end{array}$ & 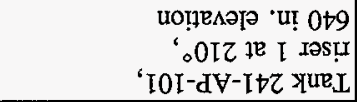 & $\varepsilon \varepsilon L \varepsilon 00 L S 6 S$ \\
\hline $\begin{array}{l}\text { ISZ00 } 0>> \\
\text { IIE00 } 0>\end{array}$ & 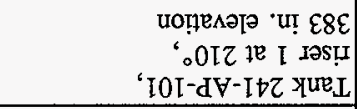 & $\tau \varepsilon L E E 00 L S 6 S$ \\
\hline $\begin{array}{l}\text { It\&00 } 0> \\
6 S 100^{\circ} 0>\end{array}$ & 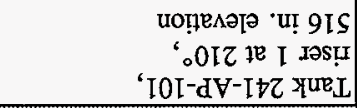 & IELE00LS6S \\
\hline 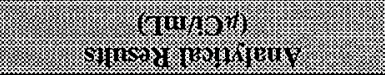 & 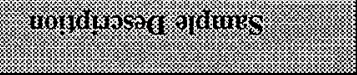 & 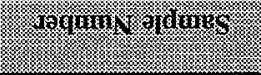 \\
\hline
\end{tabular}

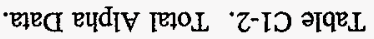




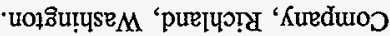

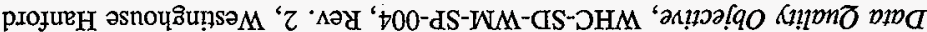

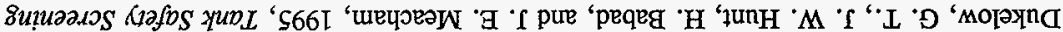

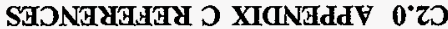

\begin{tabular}{|c|c|c|c|c|}
\hline $\mathrm{e} / \mathrm{u}$ & $\mathfrak{R} / \mathrm{U}$ & $90-3\left[8^{\circ} \circ\right.$ & 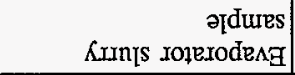 & OLZZL \\
\hline $\mathrm{e} / \mathrm{u}$ & $\mathrm{E} / \mathrm{u}$ & $90-\exists \varepsilon \tau \cdot \tau$ & 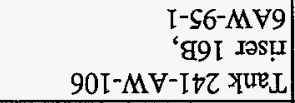 & 9l0z00LS6S \\
\hline $90-\bar{g} 9 \varepsilon^{\circ} \mathcal{\varepsilon}$ & 80-בIStי9 & $90-3 \subseteq 6^{\circ} z$ & 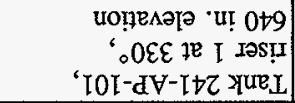 & $\angle E L E 00 L S 6 S$ \\
\hline $90-B<0^{\circ} t$ & $\angle 0-3200^{\circ} Z$ & $90-\exists 08^{\circ} z$ & 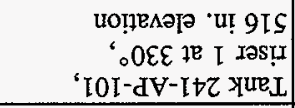 & 9ELEO0LS6S \\
\hline $90-390^{\circ} \varepsilon$ & $80^{-389^{\circ} 6}$ & $90-a s t \cdot z$ & 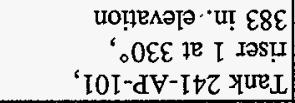 & SELE00LS6S \\
\hline $90-$ ถู9 $I^{\circ} \varepsilon$ & $\angle 0-B E I^{\circ} I$ & $90-3 s t^{\circ} Z$ & 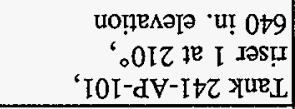 & $\varepsilon \varepsilon \angle \varepsilon 00 L S 6 S$ \\
\hline $90-\pi z 8^{\circ} Z$ & $80-\exists Z \varpi^{\circ} 2$ & $90-\mathrm{B} \angle 9^{\circ} Z$ & 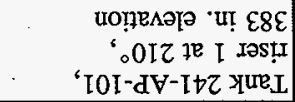 & ZELE00LS6S \\
\hline $90-799^{\circ} z$ & $60^{-}-390^{\circ} 8$ & $90-3 I S \cdot 2$ & 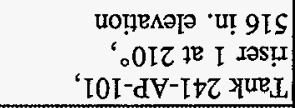 & IELE00LS6S \\
\hline (116): & $(\sqrt{1.619}$ & $(197)$ & 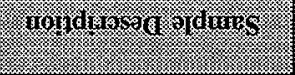 & monin. IIIIIIS \\
\hline \multicolumn{5}{|c|}{ 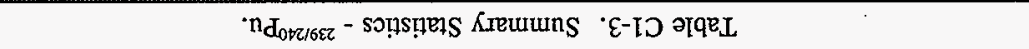 } \\
\hline
\end{tabular}


HNF-SD-WM-ER-357 Rev. 1

\begin{abstract}
APPENDIX D
RESULTS OF THE EVALUATION TO ESTABLISH BEST-BASIS INVENTORY FOR TANK 241-AP-101
\end{abstract}

D-1 
HNF-SD-WM-ER-357 Rev. 1

This page intentionally left blank. 


\section{APPENDIX D}

\section{RESULTS OF THE EVALUATION TO ESTABLISH BEST-BASIS INVENTORY FOR TANK 241-AP-101}

The following evaluation provides a best-basis inventory estimate for chemical and radionuclide components in tank 241-AP-101.

Expected Waste Type

Double-Shell Slurry Feed (DSSF).

\section{D1.0 CHEMICAL INFORMATION SOURCES}

Available composition information for tank 241-AP-101 waste is as follows.

- The validation summary for tank 241-AP-101 (Miller 1993) provides characterization results from the July 1993 "bottle-on-a-string" sampling event at a time when $4,016 \mathrm{~kL}(1,061 \mathrm{kgal})$ of dilute noncomplexed waste was in the tank.

- Beginning in October 1994, the contents of tank 241-AP-108 were transferred to tank 241-AP-101. Characterization results from the June 1994 grab sampling event for tank 241-AP-108 (Miller 1994, Table 14) were used to provide a composition for this waste.

- In August 1995, 2,498 kL (660 kgal) of waste from tank 241-AP-105 were transferred to tank 241-AP-101. The composition for this waste was taken from the characterization results of the March 1993 "bottle-on-a-string" sampling event given in the TCR for tank 241-AP-105 (De Lorenzo et al. 1994, Table 5-6).

- The final report for grab samples taken in November 1995 (Esch 1996, Table 1 provides characterization results for tank 241-AP-101 after it received DSSF from tanks 241-AP-105 and 241-AP-108. 
- The 242-A Evaporator Campaign 95-1 Post Run Document (Guthrie 1996, Table 10) and the final report for the August 1995 tank 241-AW-106 grab samples (Esch 1995) provided characterization results for the $1,158 \mathrm{~kL}$ (306 kgal) of DSSF transferred from tank 241-AW-106 to tank 241-AP-101 in March 1996.

- The HDW model document (Agnew et al. 1996) provides tank content estimates derived from the Los Alamos National Laboratory model, in terms of component concentrations and inventories. A complete list of data sources used in this evaluation is in this section.

\section{D2.0 COMPARISON OF COMPONENT INVENTORY VALUES}

The HDW model (Agnew et al. 1996) provides composition estimates for waste in tank 241-AP-101 on January 1, 1994. Because tank contents have changed since that time, no comparisons between the HDW estimate and sampling data were attempted.

\section{D3.0 COMPONENT INVENTORY EVALUATION}

The following evaluation of tank contents was performed to identify potential errors and/or missing information that would influence the sample-based inventories and to estimate the current inventory in tank 241-AP-101 from sample data of contributing wastes and transfer records.

\section{D3.1 CONTRIBUTING WASTE TYPES}

At the beginning of 1994, tank 241-AP-101 contained 4,012 kL (1,060 kgal) of dilute noncomplexed waste. In a succession of alternating transfers beginning in August 1994, waste from tank 241-AP-101 was transferred to other tanks as evaporator feed and waste from tank 241-AP-108 was transferred to tank 241-AP-101. At the conclusion of the transfers, tank 241-AP-101 contained only $295 \mathrm{~kL}$ (78 kgal) of dilute noncomplexed waste.

This volume remained unchanged until August 1995 when $2,498 \mathrm{~kL}$ ( $660 \mathrm{kgal}$ ) of DSSF from tank 241-AP-105 was sent to tank 241-AP-101. Seven months later, in March 1996, another 1,158 kL (306 kgal) of DSSF from the 242-A Evaporator Campaign 95-1 was added to tank 241-AP-101. This DSSF was stored in tank 241-AW-106 before it was transferred to tank 241-AP-101. Another transfer from tank 241-AW-106 (280 kL [74 kgal]) was made in . January 1997. Since of March 1997, the waste in tank 241-AP-101 has remained unchanged. 


\section{D3.2 EVALUATION OF HISTORICAL DATA}

The last sampling event for tank 241-AP-101 ended November 13,1995, approximately four months before the last transfer of DSSF from Campaign 95-1. The November 1995 data was compared to a composition derived from sample data and historical transfer information that dated back to the July 1993 sampling event. A best-basis estimate was derived for the waste by combining the reconciled November 1995 data with composition and volume information for the Campaign 95-1 DSSF (from the Campaign 95-1 post run document [Guthrie 1996] and grab sampling results from tank 241-AW-106 [Esch 1995]).

Table D3-1 shows the chronology of transfers associated with tank 241-AP-101 dating back to January 1, 1994. Analytical data for tank 241-AP-105 were taken from De Lorenzo et al. (1994), and analytical data for tank 241-AP-108 were taken from Miller (1994). Data for the DSSF from Campaign 95-1 were taken from Guthrie (1996) and Esch (1995). These data represent the waste at the time of transfer. Using these compositions and the transfer history through November 1995, a historical estimate of the contents in November 1995 was derived to compare with the analytical results of the November 1995 sampling event.

Table D3-1. Chronology of Transfers for Tank 241-AP-101 as of January 31, $1997 .{ }^{1}$

\begin{tabular}{|c|c|c|c|c|}
\hline S later & 801106 & Destination & Yolume Cling & 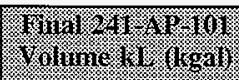 \\
\hline $1 / 1 / 94$ & $n / a$ & $\mathrm{n} / \mathrm{a}$ & $\mathrm{n} / \mathrm{a}$ & $4,012(1,060)$ \\
\hline $8 / 11 / 94$ & 241-AP-101 & 241-AW-102 & $-2,816(744)$ & $1,196(316)$ \\
\hline $10 / 7 / 94$ & 241-AP-108 & 241-AP-101 & $1,075(284)$ & $2,271(600)$ \\
\hline $10 / 8 / 94$ & $241-\mathrm{AP}-101$ & 241-AW-102 & $-1,707(451)$ & $564(149)$ \\
\hline $1 / 20 / 95$ & 241-AP-108 & 241-AP-101 & $2,896(765)$ & $3,460(914)$ \\
\hline $1 / 22 / 95$ & 241-AP-101 & 241-AP-107 & $-3,164(836)$ & $295(78)$ \\
\hline $8 / 27 / 95$ & 241-AP-105 & 241-AP-101 & $2,498(660)$ & $2,790(737)$ \\
\hline $3 / 4 / 96$ & 241-AW-106 & 241-AP-101 & $1,158(306)$ & $3,944(1,042)$ \\
\hline $1 / 9 / 97$ & 241-AW-106 & 241-AP-101 & $280(74)$ & $4,224(1,116)$ \\
\hline
\end{tabular}

Notes:

${ }^{1}$ Because minor level fluctuations are not shown, volumes may not add up exactly.

${ }^{2}$ Dates are in the $\mathrm{mm} / \mathrm{dd} / \mathrm{yy}$ format.

Table D3-2 shows the analytical results from the November 1995 sampling of tank 241-AP-101. Three samples were taken from each of two risers at depths of $678 \mathrm{~cm}$ (267 in.), $340 \mathrm{~cm}(134 \mathrm{in}$.), and $25 \mathrm{~cm}$ (10 in.) from the tank bottom for a total of six 


\begin{tabular}{|c|c|c|c|c|}
\hline $86^{\circ} 0$ & $\circ 0-\exists \vdash 0 \cdot \varepsilon$ & $t 0-700^{\circ} \varepsilon$ & $t 0-\exists 86 \cdot z$ & $\mathrm{u}_{\mathrm{V}} \mathrm{t+Z}$ \\
\hline$\therefore-$ & $\mathrm{e} / \mathrm{u}$ & $\mathrm{e} / \mathrm{u}$ & $e / u$ & Oつ $_{09}$ \\
\hline 88.0 & $96 \mathrm{I}$ & $28 \mathrm{I}$ & $\varepsilon L I$ & $\mathrm{~s}_{\underline{L \varepsilon \Omega}}$ \\
\hline $60^{\circ} \mathrm{I}$ & to- $-32 S^{\circ} \mathrm{I}$ & to-GSS I & to- $-999^{\circ} \mathrm{I}$ & $\mathrm{n}_{\mathrm{d}_{0+2 / 6 \varepsilon z}}$ \\
\hline$\varepsilon 6^{\circ} 0$ & $\varepsilon 9 I^{\circ} 0$ & $\downarrow \varepsilon\left[I^{\circ} 0\right.$ & $z S I^{\circ} 0$ & ${ }^{I} S_{06}$ \\
\hline 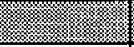 & $\ln (10 \%$ & $3 \ln (14) 1=$ & 17. & (3) \\
\hline $68^{\circ} 0$ & $0 t I^{\prime} z$ & $086^{6} \mathrm{I}$ & $016^{6} \mathrm{I}$ & -โว \\
\hline$Z \varepsilon^{*} \mathrm{~L}$ & $0 S 0^{6} z$ & OSt $\sigma^{6}$ & $00 L^{\prime} \tau$ & -4 \\
\hline$\varepsilon 8^{\circ} 0$ & $008^{6} 90$ & $00 s^{6} 0 t$ & $00 L^{\prime} 8 \mathcal{E}$ & $-2 \mathrm{ON}$ \\
\hline $18^{\circ} 0$ & S0+BI $18^{\circ} \mathrm{I}$ & $\mathrm{SO}+\mathrm{BOS}^{\cdot} \mathrm{I}$ & $\mathrm{SO}+\mathrm{B} \angle t^{\circ} \mathrm{I}$ &. $\mathrm{ON}$ \\
\hline.-- & EI9> & OIZ'I> & $0 I Z^{6} I>$ & $-\varepsilon_{-t}^{t} \mathrm{Od}$ \\
\hline$+9^{\circ} \mathrm{I}$ & $0+I^{\prime} r$ & $0 z z^{\circ} \varepsilon$ & $0 z S^{\prime} \varepsilon$ & $-z^{5} \mathrm{OS}$ \\
\hline $68^{\circ} 0$ & $\varsigma_{0}+\exists Z L \cdot I$ & $\mathrm{~S} 0+\mathrm{H} 6 \mathrm{~S}^{\prime} \mathrm{I}$ & SO+ZE\&S'I & $\mathrm{EN}_{\mathrm{N}}$ \\
\hline$\cdots$ & $\mathrm{e} / \mathrm{u}$ & $\mathrm{e} / \mathrm{u}$ & $\mathrm{e} / \mathrm{u}$ & $\partial_{\mathrm{H}}$ \\
\hline$\angle 8^{\circ} 0$ & $009^{\circ} \mathrm{ZI}$ & $009^{\circ} \mathrm{II}$ & $000^{\circ} \mathrm{LI}$ & IV \\
\hline $8 L \circ 0$ & $006^{\prime} \varepsilon S$ & $00 z^{4} 6 t$ & $00 z^{\prime} z t$ & $-\mathrm{HO}$ \\
\hline $00^{\circ} \mathrm{I}$ & $98^{\circ} \varepsilon I$ & $\angle L^{*} E I$ & $\angle 8^{\circ} \varepsilon I$ & $\mathrm{H}^{\mathrm{d}}$ \\
\hline$\angle 6^{\circ} 0$ & $\nabla \varepsilon^{\prime} I$ & $58 Z^{\circ} \mathrm{I}$ & $\$ 6 Z^{\circ} \mathrm{I}$ & 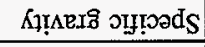 \\
\hline $90^{\circ} \mathrm{I}$ & $\% 28^{\circ} 95$ & $\% 16.8 \mathrm{~S}$ & $\% \angle t^{*} 09$ & 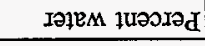 \\
\hline$S Z \cdot I$ & $00 \varepsilon^{\prime} t$ & $096^{6} t$ & $09 \varepsilon^{\prime} s$ & OIL \\
\hline $06^{\circ} 0$ & $0 \neq \varepsilon^{\prime} z$ & $090^{\prime} z$ & $00 I^{\prime} \mathrm{Z}$ & SOL \\
\hline 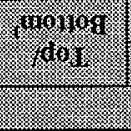 & $\frac{\ln }{46 \%}$ & 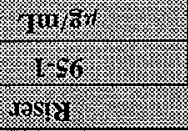 & 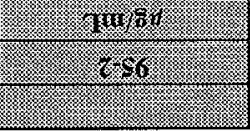 & 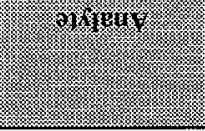 \\
\hline
\end{tabular}

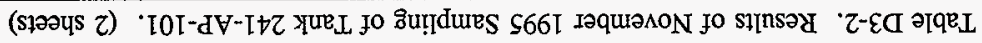

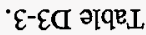

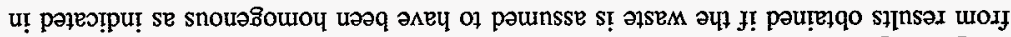

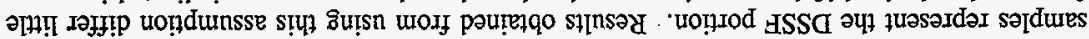

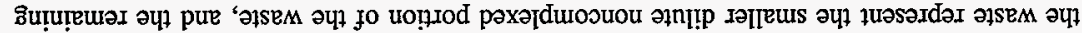

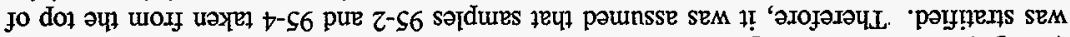

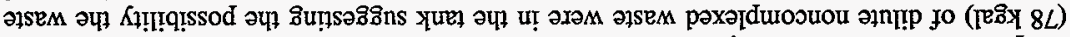

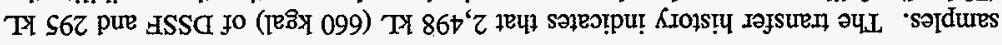


Table D3-2. Results of November 1995 Sampling of Tank 241-AP-101. (2 sheets)

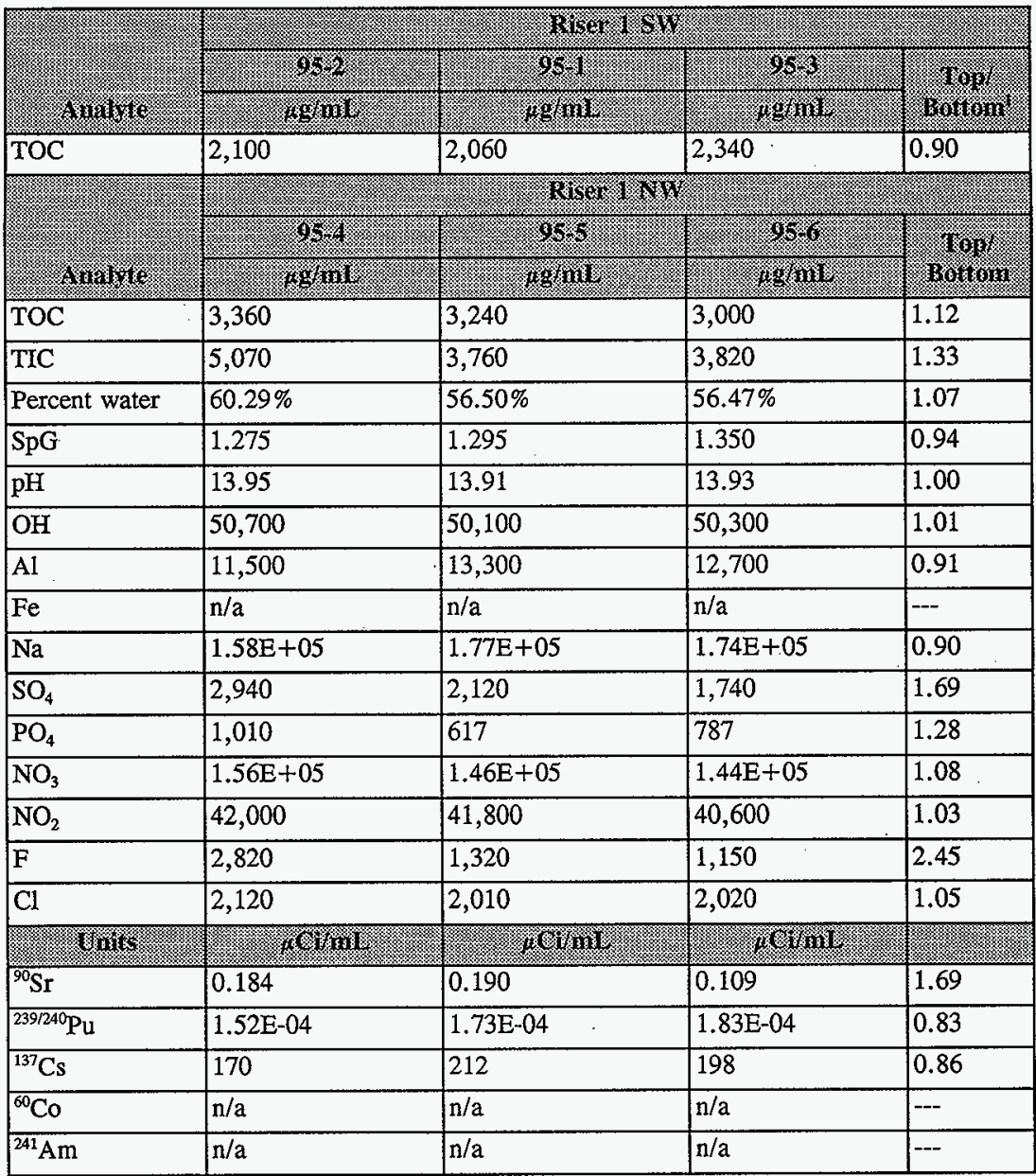

Note:

${ }^{1}$ Ratio of upper sample (95-2 or 95-4) to lower sample (95-3 or 95-6). Similar ratios might indicate stratification. 
Table D3-3. Composition of Tank 241-AP-101 as of November 1995: Homogeneity Versus Stratification.

\begin{tabular}{|c|c|c|}
\hline 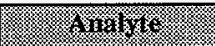 & 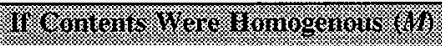 & 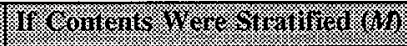 \\
\hline TOC $(g / L)$ & 2.65 & 2.66 \\
\hline $\mathrm{CO}_{3}$ & 0.378 & 0.360 \\
\hline $\mathrm{OH}$ & 2.91 & 2.97 \\
\hline $\mathrm{Al}$ & 0.449 & 0.460 \\
\hline $\mathrm{Fe}$ & $n / r$ & $n / \mathbf{r}$ \\
\hline $\mathrm{Na}$ & 7.19 & 7.34 \\
\hline $\mathrm{SO}_{4}$ & 0.0272 & 0.0250 \\
\hline $\mathrm{PO}_{4}$ & 0.00854 & 0.00775 \\
\hline $\mathrm{NO}_{3}$ & 2.48 & 2.50 \\
\hline $\mathrm{NO}_{2}$ & 0.907 & 0.918 \\
\hline $\mathbf{F}$ & 0.110 & 0.0974 \\
\hline $\mathrm{Cl}$ & 0.0573 & 0.0574 \\
\hline Vinis: & 12. (19: & (1) (1) \\
\hline${ }^{90} \mathrm{Sr}$ & $1.63 \mathrm{E}-04$ & $1.58 \mathrm{E}-04$ \\
\hline${ }^{239 / 240} \mathrm{Pu}$ & $1.64 \mathrm{E}-07$ & $1.65 \mathrm{E}-07$ \\
\hline${ }^{137} \mathrm{Cs}$ & 0.197 & 0.203 \\
\hline $241 \mathrm{Am}$ & $3.01 \mathrm{E}-07$ & $3.02 \mathrm{E}-07$ \\
\hline
\end{tabular}

Note:

$$
\mathbf{n} / \mathbf{r}=\text { not repored }
$$

Table D3-4 compares the historical estimate to the results of the November 1995 sampling event (assuming waste stratification). Overall, agreement is excellent agreement. The largest disparities were phosphate and plutonium. Because of the low plutonium concentrations, the 68 percent difference for this analyte is deemed acceptable. The phosphate disparity needs to be addressed.

The bulk of the phosphate in the historical estimate comes from tank 241-AP-105. The IC results for phosphate were chosen from De Lorenzo et al. (1994). If the ICP results for phosphorus were used instead, the resulting disparity would be decreased from 45 to 24 percent. The November 1995 analytical results are assumed to be the better basis for phosphate. 
Table D3-4. Estimated and Analytical Compositions for Waste in Tank 241-AP-101 as of November 1995. (2 sheets)

\begin{tabular}{|c|c|c|c|}
\hline$\sqrt{9-18}$ & 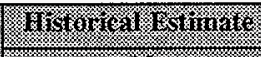 & 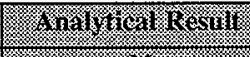 & \\
\hline (2) asialytr: & 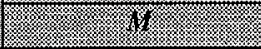 & 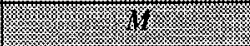 & 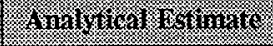 \\
\hline $\mathrm{Ag}$ & $1.15 \mathrm{E}-06$ & $n / \mathbf{r}$ & \\
\hline $\mathrm{Al}(\mathrm{OH})_{4}$ & 0.388 & 0.460 & 0.84 \\
\hline As & 1.09E-05 & $n / r$ & \\
\hline B & 0.00177 & $n / r$ & \\
\hline $\mathrm{Ba}$ & $4.17 \mathrm{E}-06$ & $n / r$ & \\
\hline $\mathrm{Ca}$ & 0.00149 & $n / r$ & \\
\hline $\mathrm{Cd}$ & $1.42 \mathrm{E}-05$ & $\mathrm{n} / \mathrm{r}$ & \\
\hline $\mathrm{Cr}(\mathrm{OH})_{4}$ & 0.00322 & $n / r$ & \\
\hline $\mathrm{Fe}$ & $1.07 \mathrm{E}-04$ & $n / r$ & \\
\hline $\mathrm{K}$ & 0.709 & $n / r$ & \\
\hline $\mathrm{Mg}$ & $3.35 \mathrm{E}-04$ & $n / r$ & \\
\hline $\mathrm{Na}$ & 6.51 & 7.34 & 0.89 \\
\hline $\mathrm{Ni}$ & $1.66 \mathrm{E}-04$ & $\mathrm{n} / \mathrm{r}$ & \\
\hline $\mathrm{Pb}$ & $2.33 \mathrm{E}-05$ & $n / r$ & \\
\hline $\mathrm{Se}$ & $1.60 \mathrm{E}-06$ & $n / r$ & \\
\hline Si & 0.00462 & $n / x$ & \\
\hline $\mathrm{Ti}$ & $1.19 \mathrm{E}-12$ & $\mathrm{n} / \mathrm{r}$ & \\
\hline $\mathrm{U} \mathrm{g} / \mathrm{L}$ & 0.0390 & $n / r$ & \\
\hline $\mathrm{Zn}$ & $8.05 \mathrm{E}-04$ & $n / r$ & \\
\hline $\mathrm{CO}_{3}$ & 0.336 & 0.360 & 0.93 \\
\hline$\overline{\mathrm{CL}}$ & 0.0597 & 0.0574 & 1.04 \\
\hline $\bar{F}$ & 0.0718 & 0.0974 & 0.74 \\
\hline $\mathrm{SO}_{4}$ & 0.0227 & 0.0250 & 0.91 \\
\hline $\mathrm{NO}_{3}$ & 2.38 & 2.50 & 0.95 \\
\hline $\mathrm{NO}_{2}$ & 0.941 & 0.918 & 1.03 \\
\hline $\mathrm{PO}_{4}$ & 0.00424 & 0.00775 & 0.55 \\
\hline$\overline{\mathrm{OH}}$ & 2.84 & 2.97 & 0.96 \\
\hline TOC $(\mathrm{g} / \mathrm{L})$ & 2.46 & 2.66 & 0.92 \\
\hline
\end{tabular}


Table D3-4. Estimated and Analytical Compositions for Waste in Tank 241-AP-101 as of November 1995. (2 sheets)

\begin{tabular}{|c|c|c|c|}
\hline & 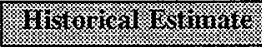 & 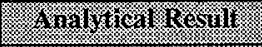 & \\
\hline (3) & m. & (1. & 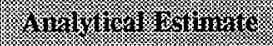 \\
\hline 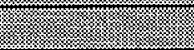 & 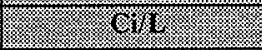 & (1) & 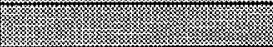 \\
\hline${ }^{14} \mathrm{C}$ & $1.95 \mathrm{E}-07$ & $\mathrm{n} / \mathrm{r}$ & \\
\hline${ }^{90} \mathrm{Sr}$ & $2.02 \mathrm{E}-04$ & $1.58 \mathrm{E}-04$ & 1.28 \\
\hline${ }^{90} \mathrm{Y}$ & 2.02E-04 & $1.58 \mathrm{E}-04$ & 1.28 \\
\hline${ }^{99} \mathrm{Tc}$ & $6.28 \mathrm{E}-05$ & $\mathrm{n} / \mathrm{r}$ & \\
\hline${ }^{137} \mathrm{Cs}$ & $2.13 \mathrm{E}-01$ & $2.03 \mathrm{E}-01$ & 1.05 \\
\hline${ }^{137} \mathrm{Ba}$ & $2.02 \mathrm{E}-01$ & $1.93 \mathrm{E}-01$ & 1.05 \\
\hline${ }^{154} \mathrm{Eu}$ & $5.32 \mathrm{E}-09$ & $n / r$ & \\
\hline${ }^{238} \mathrm{U}$ & $1.31 \mathrm{E}-08$ & $\mathrm{n} / \mathrm{r}$ & \\
\hline${ }^{237} \mathrm{~Np}$ & $2.81 \mathrm{E}-07$ & $\mathrm{n} / \mathrm{r}$ & \\
\hline${ }^{239} \mathrm{Pu}$ & $1.13 \mathrm{E}-07$ & $1.65 \mathrm{E}-07$ & 0.68 \\
\hline${ }^{241} \mathrm{Pu}$ & $1.77 \mathrm{E}-07$ & $\mathrm{n} / \mathrm{r}$ & \\
\hline${ }^{241} \mathrm{Am}$ & $3.63 \mathrm{E}-07$ & $3.02 \mathrm{E}-07$ & 1.20 \\
\hline
\end{tabular}

The November 1995 sample analysis did not include a large number of components that are in the historical estimate. For these components, the historical estimate is used as the basis. Table D3-5 shows the best-basis inventory for waste in tank 241-AP-101 before the final transfer of DSSF from Campaign 95-1. 
Table D3-5. Estimated and Analytical Inventories for Waste in Tank 241-AP-101 as of November 1995. (2 sheets)

\begin{tabular}{|l|l|}
\hline & \\
\hline $\mathrm{Al}$ & 34,700 \\
\hline $\mathrm{B}$ & 0.00177 \\
\hline $\mathrm{Ca}$ & 237 \\
\hline $\mathrm{Cr}$ & 662 \\
\hline $\mathrm{Fe}$ & 23.5 \\
\hline $\mathrm{K}$ & $1.09 \mathrm{E}+05$ \\
\hline $\mathrm{Na}$ & $4.71 \mathrm{E}+05$ \\
\hline $\mathrm{Ni}$ & 38.5 \\
\hline $\mathrm{Pb}$ & 19.0 \\
\hline $\mathrm{Si}$ & 512 \\
\hline $\mathrm{U}$ & 154 \\
\hline $\mathrm{CO}$ & 60,300 \\
\hline $\mathrm{CL}$ & 5,680 \\
\hline $\mathrm{F}$ & 5,160 \\
\hline $\mathrm{SO}_{4}$ & 6,700 \\
\hline $\mathrm{NO}_{3}$ & $4.33 \mathrm{E}+05$ \\
\hline $\mathrm{NO}_{2}$ & $1.18 \mathrm{E}+05$ \\
\hline $\mathrm{PO}_{4}$ & 2,050 \\
\hline $\mathrm{OH}$ & $1.41 \mathrm{E}+05$ \\
\hline $\mathrm{TOC}$ & 7,420 \\
\hline & \\
\hline & \\
\hline
\end{tabular}


Table D3-5. Estimated and Analytical Inventories for Waste in Tank 241-AP-101 as of November 1995. (2 sheets)

\begin{tabular}{|l|l|}
\hline${ }^{14} \mathrm{C}$ & ind \\
\hline${ }^{90} \mathrm{Sr}$ & $1.95 \mathrm{E}-07$ \\
\hline${ }^{90} \mathrm{Y}$ & 564 \\
\hline${ }^{99} \mathrm{Tc}$ & 564 \\
\hline${ }^{137} \mathrm{Cs}$ & 175 \\
\hline${ }^{137} \mathrm{Ba}$ & $5.67 \mathrm{E}+05$ \\
\hline${ }^{154} \mathrm{Eu}$ & $5.39 \mathrm{E}+05$ \\
\hline${ }^{238} \mathrm{U}$ & 0.0149 \\
\hline${ }^{237} \mathrm{~Np}$ & 0.0518 \\
\hline${ }^{239} \mathrm{Pu}$ & 0.785 \\
\hline${ }^{241} \mathrm{Pu}$ & 0.461 \\
\hline${ }^{241} \mathrm{Am}$ & 0.494 \\
\hline
\end{tabular}

Note:

'This is the inventory before addition of $1,158 \mathrm{~kL}$ (306 kgal) of DSSF from tank 241-AW-106 in March 1996 (Campaign 95-1).

Once the waste composition for November 1995 was established, it was necessary to estimate a current composition for tank 241-AP-101 by "adding" the 1,438 kL (380 kgal) of DSSF that was produced in Campaign 95-1 and stored in tank 241-AW-106 before it was transferred to tank 241-AP-101. The concentration estimates for the additional portion were derived by combining the results from a sample of the 242-A Evaporator slurry and the results from an August 1995 grab sampling of tank 241-AW-106. The combining was done as discussed in Section B3.4. Table D3-6 shows the concentration estimates for the additional portion. 
Table D3-6. Concentration Estimates for Waste Received from Tank 241-AW-106 in March 1996 and January 1997.

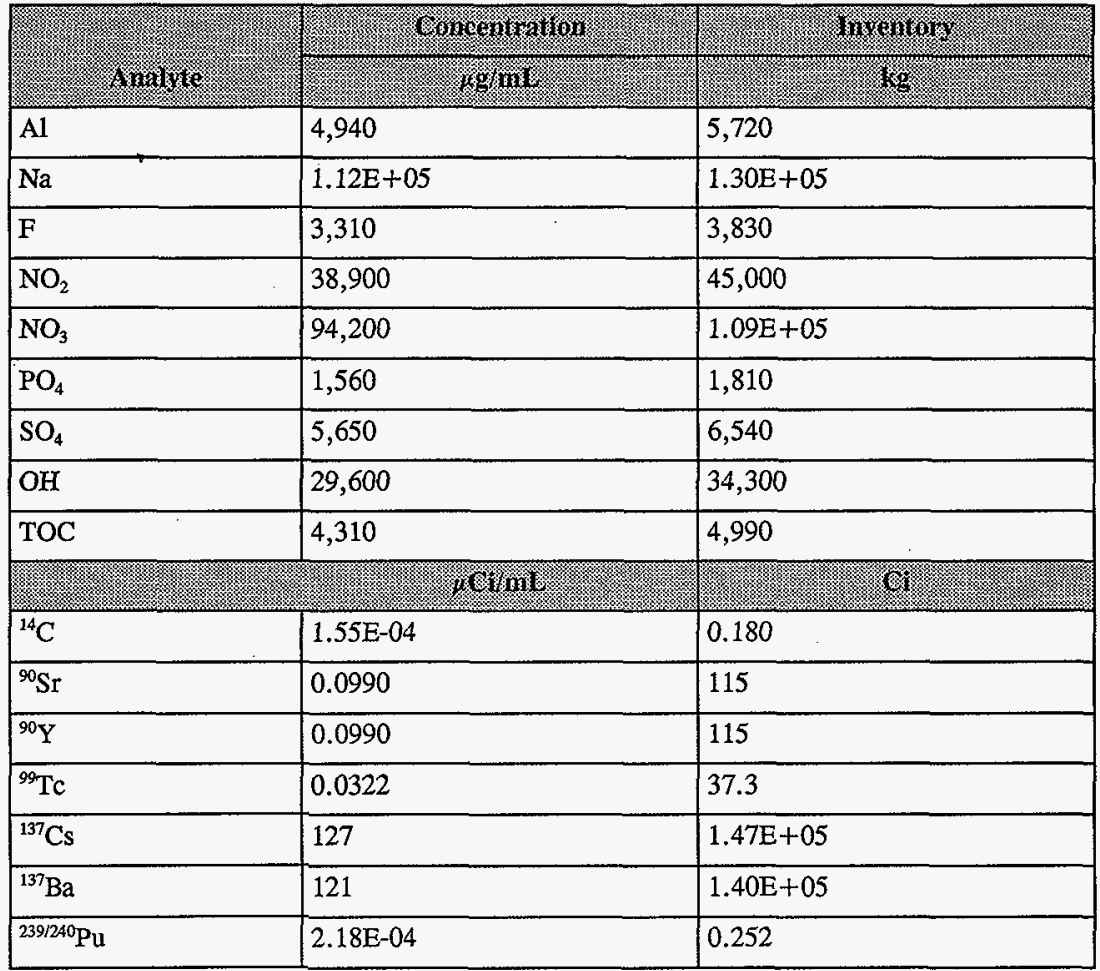

In combining the November 1995 basis with the DSSF from Campaign 95-1, component inventories in the November 1995 basis that were not included in the Campaign 95-1 data were assumed to be the total inventories for the tank. This introduces considerable uncertainty for these components, but in the absence of other data, the result of this analysis is the best-basis for the tank. 


\section{D4.0 DEFINE THE BEST BASIS AND ESTABLISH COMPONENT INVENTORIES}

The sample-based data should serve as the basis for the best estimate inventory for tank 241-AP-101 for the following reasons:

1. Although no individual samples of the waste are currently stored in tank 241-AP-101, data from the tank samples taken in November 1995 and data from the waste produced in Evaporator Campaign 95-1 can be combined to describe waste currently in tank 241-AP-101.

2. The HDW model estimate is outdated because of a large number of waste transfers that have occurred subsequent to the model development.

Tables D4-1 and D4-2 show best-basis inventory estimates for tank 241-AP-101. Radionuclide values are decayed to January 1, 1994.

Table D4-1. Best-Basis Inventory Estimates for Nonradioactive Components in Tank 241-AP-101 as of September 30, 1996. (2 sheets)

\begin{tabular}{|c|c|c|c|}
\hline (1) & 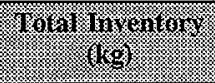 & $(8,14,010.19$ & Caminent: \\
\hline $\mathrm{Al}$ & 40,400 & $S$ & \\
\hline $\mathrm{Ca}$ & 237 & $S$ & Campaign 95-1 data not available. \\
\hline $\mathrm{Cl}$ & 5,680 & $S$ & \\
\hline $\mathrm{TIC}$ as $\mathrm{CO}_{3}^{2-}$ & $1.13 \mathrm{E}+05$ & $S$ & \\
\hline $\mathrm{Cr}$ & 662 & $S$ & Campaign $95-1$ data not available. \\
\hline $\mathrm{F}$ & 8,990 & $S$ & \\
\hline $\mathrm{Fe}$ & 23.5 & $s$ & \\
\hline $\mathrm{K}$ & $1.09 \mathrm{E}+05$ & $S$ & Campaign $95-1$ data not available. \\
\hline $\mathrm{Na}$ & $6.01 E+05$ & $S$ & \\
\hline $\mathrm{Ni}$ & 38.5 & $\mathrm{~s}$ & Campaign $95-1$ data not available. \\
\hline $\mathrm{NO}_{2}^{-}$ & $1.63 E+05$ & $S$ & \\
\hline $\mathrm{NO}_{3}^{-}$ & $5.42 \mathrm{E}+05$ & $S$ & \\
\hline $\mathrm{OH}^{-}$ & $1.75 E+05$ & $\mathrm{~S}$ & \\
\hline
\end{tabular}


Table D4-1. Best-Basis Inventory Estimates for Nonradioactive Components in Tank 241-AP-101 as of September 30, 1996. (2 sheets)

\begin{tabular}{|c|c|c|c|}
\hline : 1 mante & 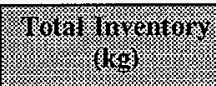 & 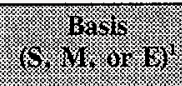 & (9ommanis: \\
\hline $\mathrm{Pb}$ & 19.0 & $\mathrm{~S}$ & Campaign $95-1$ data not available. \\
\hline $\mathrm{PO}_{4}$ & 4,280 & $S$ & $\begin{array}{l}45 \text { percent disparity between } \\
\text { historical and analytical results. }\end{array}$ \\
\hline $\mathrm{Si}$ & 512 & $S$ & Campaign $95-1$ data not available. \\
\hline $\mathrm{SO}_{4}$ & 13,400 & $S$ & \\
\hline TOC & 12,400 & $S$ & \\
\hline $\mathrm{U}_{\text {TOTAL }}$ & 191 & $S$ & \\
\hline
\end{tabular}

Note:

${ }^{1} \mathrm{~S}=$ sample-based, $\mathrm{M}=$ HDW model-based, $\mathrm{E}=$ engineering assessment-based

Table D4-2. Best-Basis Inventory Estimates for Radioactive Components in Tank 241-AP-101 as of September 30, 1996 (Decayed to January 1, 1994).

\begin{tabular}{|c|c|c|c|}
\hline . & 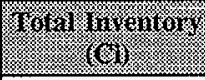 & 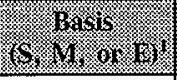 & ( \\
\hline${ }^{14} \mathrm{C}$ & 0.744 & $\mathrm{~S}$ & \\
\hline${ }^{90} \mathrm{Sr}$ & 679 & $S$ & \\
\hline${ }^{90} \mathrm{Y}$ & 679 & $S$ & \\
\hline${ }^{99} \mathrm{Tc}$ & 212 & $S$ & \\
\hline${ }^{137} \mathrm{Cs}$ & $7.14 \mathrm{E}+05$ & $S$ & \\
\hline${ }^{137 \mathrm{~m}} \mathrm{Ba}$ & $6.78 \mathrm{E}+05$ & $S$ & \\
\hline${ }^{154} \mathrm{Eu}$ & 210 & & \\
\hline${ }^{237} \mathrm{~Np}$ & 1.11 & $S$ & Campaign 95-1 data not available. \\
\hline${ }^{238} \mathrm{U}$ & 0.0518 & $S$ & Campaign 95-1 data not available. \\
\hline${ }^{239 / 240} \mathrm{Pu}$ & 0.713 & $S$ & \\
\hline${ }^{241} \mathrm{Am}$ & 0.843 & $S$ & \\
\hline
\end{tabular}

Note:

'S = sample-based, $\mathrm{M}=\mathrm{HDW}$ model-based, $\mathrm{E}=$ engineering assessment-based 


\section{D5.0 APPENDIX D REFERENCES}

Agnew, S. F., J. Boyer, R. A. Corbin, T. B. Duran, J. R. FitzPatrick, K. A. Jurgensen, T. P. Ortiz, and B. L. Young, 1996, Hanford Tank Chemical and Radionuclide Inventories: HDW Model Rev. 3, LA-UR-96-858, Rev. 0, Los Alamos National Laboratory, Los Alamos, New Mexico.

De Lorenzo, D. S., L. C. Amato, A. T. DiCenso, K. W. Johnson, and R. H. Stephens, 1994, Tank Characterization Report for Double-Shell Tank 241-AP-105, WHC-SD-WM-ER-360, Rev. 0, Westinghouse Hanford Company, Richland, Washington.

Esch, R. A., 1995, 60-Day Waste Compatibility Safety Issue and Final Results for Tank 241-AW-106, Grab Samples 6AW-95-1, 6AW-95-2, and 6AW-95-3, WHC-SD-WM-DP-147, Rev. 0, Westinghouse Hanford Company, Richland, Washington.

Esch, R. A., 1996, Final Report for Tank 241-AP-101 Grab Samples 1AP-95-1 \& 1AP-95-2 \& 1AP-95-3 \& 1AP-95-4 \& 1AP-95-5 \& 1AP-95-6, WHC-SD-WM-DP-161, Rev. 0 , Westinghouse Hanford Company, Richland, Washington.

Guthrie, M. D., 1996, 242-A Campaign 95-1 Post Run Document, WHC-SD-WM-PE-055, Rev. 0, Westinghouse Hanford Company, Richland, Washington.

Miller, G. L., 1993, Validation Summary for Double-Shell Tank 241-AP-101, WHC-SD-WM-DP-051, Addendum 1, Rev. 0, Westinghouse Hanford Company, Richland, Washington.

Miller, G. L., 1994, Analysis and Characterization of Double-Shell Tank 241-AP-108, WHC-SD-WM-DP-065, Rev. 0, Westinghouse Hanford Company, Richland, Washington. 
HNF-SD-WM-ER-357 Rev. 1

APPENDIX E

BIBLIOGRAPHY FOR TANK 241-AP-101

$\mathrm{E}-1$ 
HNF-SD-WM-ER-357 Rev. 1

This page intentionally left blank. 


\section{APPENDIX E \\ BIBLIOGRAPHY FOR TANK 241-AP-101}

Appendix $\mathrm{E}$ is a bibliography of information that supports the characterization of tank 241-AP-101. This bibliography represents an in-depth literature search of all known information sources that provide sampling, analysis, surveillance, and modeling information, as well as processing occurrences associated with tank 241-AP-101 and its respective waste types.

The references in this bibliography are separated into three broad categories containing references broken down into subgroups. These categories and their subgroups are listed below.

\section{NON-ANALYTICAL DATA}

Ia. Models/Waste Type Inventories/Campaign Information

Ib. Fill History/Waste Transfer Records

Ic. Surveillance/Tank Configuration

Id. Sample Planning/Tank Prioritization

Ie. Data Quality Objectives/Customers of Characterization Data

If. Other - Nondocumented or Electronic Sources

\section{ANALYTICAL DATA - SAMPLING OF TANK WASTE AND WASTE TYPES}

IIa. Sampling of tank 241-AP-101

IIb. Sampling of 242-A Evaporator Streams

IIc. Sampling of Similar Waste Types

\section{COMBINED ANALYTICAL/NON-ANALYTICAL DATA}

IIIa. Inventories using both Campaign and Analytical Information

IIIb. Compendium of Existing Physical and Chemical Documented Data Sources

This bibliography is broken down into the appropriate sections and has an annotation at the end of each reference describing the information source. Whenever possible, a reference is provided for information sources. A majority of the information listed below is available in the Tank Characterization Resource Center. 


\section{NON-ANALYTICAL DATA}

Ia. Models/Waste Type Inventories/Campaign Information

Agnew, S. F., J. Boyer, R. A. Corbin, T. B. Duran, J. R. Fitzpatrick, K. A. Jurgensen, T. P. Ortiz, and B. L. Young, 1997, Hanford Tank Chemical and Radionuclide Inventories: HDW Model Rev. 4, LA-UR-96-3680, Rev. 0, Los Alamos National Laboratory, Los Alamos, New Mexico.

- Contains waste type summaries and primary chemical compound/analyte and radionuclide estimates for liquids and solids based on campaign information.

\section{Ib. Fill History/Waste Transfer Records}

Agnew, S. F., P. Baca, R. A. Corbin, T. B. Duran, and K. A. Jurgensen, 1997, Waste Tank Status and Transaction Record Summary for the Southeast Quadrant, (WSTRS), Rev. 4, LA-UR-97-311 Los Alamos National Laboratory, Los Alamos, New Mexico.

- Contains spreadsheets showing available data on tank additions and transfers.

Koreski, G. M., and J. Strode, 1994, Operational Waste Volume Projection, WHC-SD-WM-ER-029, Rev. 20, Westinghouse Hanford Company, Richland, Washington.

- Includes spreadsheets detailing double-shell tank waste transfers.

\section{Ic. Surveillance/Tank Configuration}

Brevick, C. H., L. A. Gaddis, and S. D. Consort, 1995, Supporting Document for the Southeast Quadrant Historical Tank Content Estimate Report for AP Tank Farm - Volume 1 and 2, WHC-SD-WM-ER-315, Rev. 0, Westinghouse Hanford Company, Richland, Washington.

- Summarizes tank farm historical information including the following: historical analytical results, surveillance level data and graphs, riser configurations, tank photographs, inventory estimates, and layering model data. 
Hanlon, B. M., 1997, Waste Tank Summary Report for Month Ending January 31, 1997, WHC-EP-0182-106, Lockheed Martin Hanford Company, Richland, Washington.

- Most recent release of a series of summaries including fill volumes, Watch List tanks, occurrences, integrity information, equipment readings, equipment status, tank location, and other miscellaneous tank information. The series includes monthly summaries from December 1947 to the present; however, Hanlon has only authored the monthly summaries from November 1989 to the present.

KEH, 1982, "Plan Tank Penetrations 241-AP-101 and 103," Drawing H-2-90538, Rev. 1, Kaiser Engineers Hanford Company, Richland, Washington.

- Shows a top down view of riser locations.

Leach C. E., and S. M. Stahl, 1996, Hanford Site Tank Farm Interim Safety Basis, WHC-SD-WM-ISB-001, Rev. OL, Westinghouse Hanford Company, Richland, Washington.

- Details tank design, designed use, construction, and equipment information.

Lipnicki, J., 1996, Waste Tank Risers Available for Sampling, WHC-SD-WM-TI-710, Rev. 3, Westinghouse Hanford Company, Richland, Washington.

- Assesses riser locations for each tank; not all tanks are included or completed.

Salazar, B. E., 1994, Double-Shell Underground Waste Tanks Riser Survey, WHC-SD-RE-TI-093, Rev. 4, Westinghouse Hanford Company, Richland, Washington.

- A compilation of riser information for double-shell tanks. Includes above ground plan views, riser sizes and elevations, and tank reference drawing numbers.

Tran, T. T., 1993, Thermocouple Status: Single-Shell and Double-Shell Waste Tanks, WHC-SD-WM-TI-553, Rev. 0, Westinghouse Hanford Company, Richland, Washington.

- Unvalidated compilation of thermocouple information for all tanks. Includes source document references. 
WHC, 1994, "Piping Plan Tank 101," Drawing H-2-90553, Rev. 4, Westinghouse Hanford Company, Richland, Washington.

- Shows a top down view of the riser locations and piping.

\section{Id. Sample Planning/Tank Prioritization}

Bratzel, D. R., 1994, Letter of Instruction for Tank 241-AP-1-1 Grab Samples, (internal letter 7E720-94-145 to J. G. Kristofski, December 12), Westinghouse Hanford Company, Richland, Washington.

- Requests analysis of two samples taken to determine whether tank 241-AP-101 was within tank corrosion control specififications.

Brown, T. M., J. W. Hunt, S. J. Eberlein, and T. J. Kunthara, 1996, Tank Waste Characterization Basis, WHC-SD-WM-TA-164, Rev. 1, Westinghouse Hanford Company, Richland, Washington.

- Summarizes the technical basis for characterizing waste in tanks and assigns a priority number to each tank.

Ecology, EPA, and DOE, 1994, Hanford Federal Facility Agreement and Consent Order, as amended, Washington State Department of Ecology, U.S. Environmental Protection Agency, and U.S. Department of Energy, Olympia, Washington.

- Contains the agreement between EPA, DOE, and Ecology that sets milestones for completing work on the Hanford Site tank farms.

Esch, R. A., 1995, Tank 241-AP-101 Grab Sampling and Analysis Plan, WHC-SD-WM-TSAP-062, Rev. 0A, Westinghouse Hanford Company, Richland, Washington.

- Details sampling and analysis procedures for the November 1995 grab sampling.

Homi, C. S., 1995, Tank 241-Ap-101 Tank Characterization Plan, WHC-SD-WM-TP-417, Rev. 0, Westinghouse Hanford Company, Richland, Washington.

- Describes safety and operational issues for which samples are necessary. 
Jones, J. M., 1995, Compatibility Grab Sampling and Analysis Plan, WHC-SD-WM-TSAP-037, Rev. 1, Westinghouse Hanford Company, Richland, Washington.

- Details the plan which serves as the contractual agreement for the Characterization Program, Sampling Operations, and the 222-S Laboratory. The plan provides guidance for the sampling and analysis of samples for waste compatibility purposes.

Le, E. Q., 1995, 242-A Evaporator Sample Schedule for Campaign 95-1, FSS-T-630-00001, Rev. B-5, Westinghouse Hanford Company, Richland, Washington.

- Describes the sampling schedule to be used during the 242-A Evaporator Campaign 95-1.

Schreiber, R. D., 1995, Letter of Instruction for Tank 241-Ap-101 Grab Samples, (internal memorandum 71520-95-107 to A. D. Rice, March 15), Westinghouse Hanford Company, Richland, Washington.

- Describes analyses needed on two grab samples to determine whether the tank was within corrosion control specifications.

Ie. Data Quality Objectives and Customers of Characterization Data

Dukelow, G. T., J. W. Hunt, H. Babad, and J. E. Meacham, 1995, Tank Safety Screening Data Quality Objective, WHC-SD-WM-SP-004, Rev. 2, Westinghouse Hanford Company, Richland, Washington.

- Used to determine whether tanks are operating safely.

Fowler, K. D., 1995, Data Quality Objectives for Tank Farms Waste Compatibility Program, WHC-SD-WM-DQO-001, Rev. 1, Westinghouse Hanford Company, Richland, Washington.

- Establishes the process for assessing waste compatibility for transfers into and within the double-shell tank system.

\section{If. Other - Nondocumented or Electronic Sources}

Koreski, G. M., 1997, Operational Waste Volume Projection Historical Database, Lockheed Martin Hanford Corporation, Richland, Washington.

- Contains spreadsheets showing transfer activity for double-shell tanks. 
Lockheed Martin Services, 1997, SACS: Surveillance Analysis Computer System. In: SYBASE/Visual Basic [Mainframe]. Available: HLAN, Lockheed Martin Services, Richland, WA; or Tank Waste Information Network System, Pacific Northwest National Laboratory, Richland, Washington.

- Contains 200 Area tank surveillance data from the Computer Austomated Surveillance System and the Tank Monitoring and Control System.

\section{ANALYTICAL DATA - SAMPLING OF TANK WASTE AND WASTE TYPES}

Ia. Sampling of Tank 241-AP-101

Esch, R. A., 1996, Final Report for Tank 241-AP-101, Grab Samples 2AP-95-1, 2AP-95-2, 2AP-95-3, 2AP-95-4, 2AP-95-5, and 2AP-95-6, WHC-SD-WM-DP-161, Rev. 1, Westinghouse Hanford Company, Richland, Washington.

- Shows the analytical results from the November 1995 grab sampling.

Miller, G. L., 1993, 222-S Validation Summary for Double-Shell Tank 241-AP-101, WHC-SD-WM-DP-051, Rev. 0, Westinghouse Hanford Company, Richland, Washington.

- Shows the analytical results from the July 1993 grab sampling.

Rollison, M. D., 1995, Results for 241-AP-101 Grab Samples, (internal memorandum 8E480-95-022 to J. M. Jones, April 10), Westinghouse Hanford Company, Richland, Washington.

- Shows results from the March 1995 grab sampling.

Rollison, M. D., 1995, Results for Tank 241-AP-101, (internal memorandum 8E480-95-001 to J. M. Jones, January 19), Westinghouse Hanford Company, Richland, Washington.

- Shows results from the December 1994 grab sampling. 


\section{mb. Sampling of Evaporator Waste Streams}

Guthrie, M. D., 1995, 242-A Campaign 94-2 Post Run Document, WHC-SD-WM-PE-054, Rev. 0, Westinghouse Hanford Company, Richland, Washington.

- $\quad$ Summarizes the results of 242-A Evaporator Campaign 94-2.

Guthrie, M. D., 1996, 242-A Campaign 95-1 Post Run Document, WHC-SD-WM-PE-055, Rev. 0, Westinghouse Hanford Company, Richland, Washington.

- Summarizes the results of 242-A Evaporator Campaign 95-1.

Jonas, A. L., 1989, 242 A Evaporator FY 1989 Campaign Run 89-1 Post Run Document, WHC-SD-WM-PE-037, Rev. 0, Westinghouse Hanford Company, Richland, Washington.

- Summarizes the results of 242-A Evaporator Campaign 89-1.

Miller, G. L., 1994, Organic Verification Data for Evaporator Projects for Tanks 241-AP-101 and 107, WHC-SD-WM-DP-063, Rev. 0, Westinghouse Hanford Company, Richland, Washington.

- Contains organic speciation data for tanks 241-AP-101 and 241-AP-107.

\section{IIc. Sampling of Similar Waste Types}

De Lorenzo, D. S., L. C. Amato, A. T. DiCenso, K. W. Johnson, and R. H. Stephens, 1994, Tank Characterization Report for Double-Shell Tank 241-AP-105, WHC-SD-WM-ER-360, Rev. 0, Westinghouse Hanford Company, Richland, Washington.

- Describes and characterizes the waste in tank 241-AP-105 based on the March 1993 grab sampling.

Esch, R. A., 1995, 60-Day Waste Compatibility Safety Issue and Final Results for Tank 241-AW-106, Grab Samples 6AW-95-1, 6AW-95-2, and 6AW-95-3, WHC-SD-WM-DP-147, Rev. 0, Westinghouse Hanford Company, Richland, Washington.

- Shows the results from the August 1995 grab sampling of tank 241-AW-106. 
Miller, G. L., 1994, Analysis and Characterization of Double-Shell Tank 241-AP-108, WHC-SD-WM-DP-065, Rev. 0, Westinghouse Hanford Company, Richland, Washington.

- Shows sampling and analytical data for tank 241-AP-108.

\section{COMBINED ANALYTICAL/NON-ANALYTICAL DATA}

\section{IIIa. Inventories from Campaign and Analytical Information}

Agnew, S. F., J. Boyer, R. A. Corbin, T. B. Duran, J. R. Fitzpatrick, K. A. Jurgensen, T. P. Ortiz, and B. L. Young, 1997, Hanford Tank Chemical and Radionuclide Inventories: HDW Rev. 4, LA-UR-96-3680, Rev. 0, Los Alamos National Laboratory, Los Alamos, New Mexico.

- Contains waste type summaries and primary chemical compound/analyte and radionuclide estimates for sludge, supernatant, and solids.

Kupfer, M. J., 1996, Interim Report: Best Basis Total Chemical and Radionuclide Inventories in Hanford Site Tank Waste, WHC-SD-WM-TI-740, Rev. D-Draft, Westinghouse Hanford Company, Richland, Washington.

- Contains a global component inventory for 200 Area waste tanks. Fourteen chemical and two radionuclide components currently are inventoried.

Schmittroth, F. A., 1995, Inventories for Low-Level Tank Waste, WHC-SD-WM-RPT-164, Rev. 0, Westinghouse Hanford Company, Richland, Washington.

- Contains a global inventory based on process knowledge and radioactive decay estimations using ORIGEN2. Pu and $U$ waste contributions are taken at one percent of the amount used in processes. Also compares information on Tc-99 from ORIGEN2 and analytical data. 


\section{IIIb. Compendium of Data From Other Sources Physical and Chemical}

Agnew, S. F., and J. G. Watkin, 1994, Estimation of Limiting Solubilities for Ionic Species in Hanford Waste Tank Supernate, LA-UR-94-3590, Los Alamos National Laboratory, Los Alamos, New Mexico.

- Gives solubility ranges used for key chemical and radionuclide components based on supernatant sample analysis.

Brevick, C. H., L. A. Gaddis, and S. D. Consort, 1995, Supporting Document for the Southeast Quadrant Historical Tank Content Estimate Report for AP Tank Farm - Volume 1 and 2, WHC-SD-WM-ER-315, Rev. 0, Westinghouse Hanford Company, Richland, Washington.

- Summarizes tank farm historical information including the following: historical analytical results, surveillance level data and graphs, riser configurations, tank photographs, inventory estimates, and layering model data.

Brevick, C. H., L. A. Gaddis, and E. D. Johnson, 1995, Tank Waste Source Term Inventory Validation, Vol I \& II., WHC-SD-WM-ER-400, Rev. 0, Westinghouse Hanford Company, Richland, Washington.

- Contains a quick reference to sampling information in spreadsheet or graphical form for 23 chemicals and 11 radionuclides for all tanks.

Brevick, C. H., J. W. Funk, G. A. Lisle, C. V. Salois, and M. R. Umphrey, 1997, Historical Tank Content Estimate for the Southeast Quadrant of the Hanford 200 Area, Fluor Daniel Northwest, Inc., Richland, Washington.

- Summarizes tank farm historical information including the following: historical analytical results, surveillance level data and graphs, riser configurations, tank photographs, inventory estimates, and layering model data.

DeLorenzo, D. S., A. T. DiCenso, D. B. Hiller, K. W. Johnson, J. H. Rutherford, D. J. Smith, and B. C. Simpson, 1994, Tank Characterization Reference Guide, WHC-SD-WM-TI-648, Rev. 0, Westinghouse Hanford Company, Richland, Washington.

- Provides overview of issues and history surrounding sampling, analysis, and modeling activities that support waste characterization. 
Hanlon, B. M., 1997, Waste Tank Summary Report for Month Ending January 31, 1997, HNF-EP-0182-106, Lockheed Martin Hanford Corporation, Richland, Washington.

- Provides a monthly summary of the following: fill volumes, Watch List tanks, occurrences, integrity information, equipment reading, equipment status, tank location, and other miscellaneous tank information.

Hartley, S. A., G. Chen, C. A. LoPresti, T. M. Ferryman, A. M. Liebetrau, K. M. Remund, S. A. Allen, and B. C. Simpson, 1996, A Comparison of Historical Tank Content Estimate (HTCE) Model, Rev. 3, and Sample-Based Estimates of Hanford Waste Tank Contents, PNL-11429 Pacific Northwest National Laboratory, Richland, Washington.

- Contains a statistical evaluation of the HDW inventory estimate against analytical values from 12 TCR reports using a select component data set.

Husa, E. I., 1993, Hanford Site Waste Storage Tank Information Notebook, WHC-EP-0625, Rev. 0, Westinghouse Hanford Company, Richland, Washington.

- Contains in-tank photos and summaries on the tank description, leak detection system, and tank status.

Husa, E. I., 1995, Hanford Waste Tank Preliminary Dryness Evaluation, WHC-SD-WM-TI-703, Rev. 0, Westinghouse Hanford Company, Richland, Washington.

- Assesses relative dryness between tanks.

Remund, K. M., and B. C. Simpson, 1995, Hanford Waste Tank Grouping Study, PNL-11433, Pacific Northwest Laboratory, Richland, Washington.

- Contains a statistical evaluation to group tanks into classes with similar waste products.

Shelton, L. W., 1996, Chemical and Radionuclide Inventory for Single and Double Shell Tanks, (internal memorandum 74A20-96-30 to D. J. Washenfelder, February 28), Westinghouse Hanford Company, Richland, Washington.

- Contains an tank inventory estimate based on analytical information. 
Shelton, L. W., 1995, Chemical and Radionuclide Inventory for Single and Double Shell Tanks, (internal memorandum 75520-95-007 to R. M. Orme, August 8), Westinghouse Hanford Company, Richland, Washington.

- Contains a tank inventory estimate based on analytical information.

Shelton, L. W., 1995, Radionuclide Inventories for Single and Double Shell Tanks, (internal memorandum to F. M. Cooney, 71320-95-002, February 14), Westinghouse Hanford Company, Richland, Washington.

- Contains an tank inventory estimate based on analytical information.

Van Vleet, R. J., 1993, Radionuclide and Chemical Inventories for DoubleShell Tanks, WHC-SD-WM-TI-543, Rev. 1, Westinghouse Hanford Company, Richland, Washington.

- Contains tank inventories generated in support of safety analyses.

WHC, 1993, Process Aids: A Compilation of Technical Letters By Process Laboratories and Technology, WHC-IP-0711-25, Westinghouse Hanford Company, Richland, Washington.

- Contain a collection of internal memorandums and letters concerning tank or process sampling. Includes all process aids documents from 1969 to 1993. 
HNF-SD-WM-ER-357 Rev. 1

This page intentionally left blank. 


\section{DISTRIBUTION SHEET}

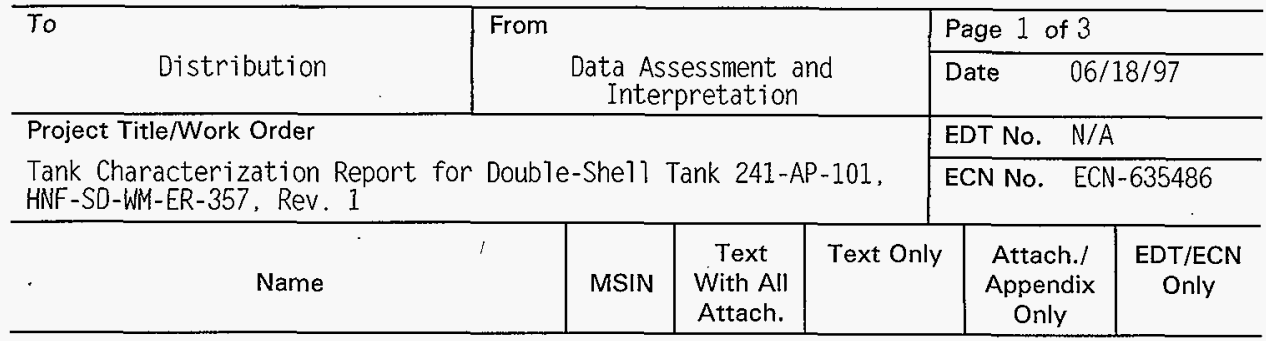

\section{OFFSITE}

Sandia National Laboratory

P.0. Box 5800

MS-0744, Dept. 6404

Albuquerque. NM 87815

D. Powers

Nuclear Consulting Services Inc.

P. 0. Box 29151

Columbus, OH 43229-01051

J. L. Kovach

Chemical Reaction Sub-TAP

P. O. Box 271

Lindsborg, KS 67456

B. C. Hudson

$x$

Tank Characterization Pane1

Senior Technical Consultant

Contech

7309 Indian School Road

Albuquerque, NM 87110

J. Arvisu

SAIC

20300 Century Boulevard, Suite 200-B

Germantown, MD 20874

H. Sutter

Los Al amos Laboratory

CST-14 MS-J586

P. 0 . Box 1663

Los ATamos, NM 87545

S. F. Agnew 


\section{DISTRIBUTION SHEET}

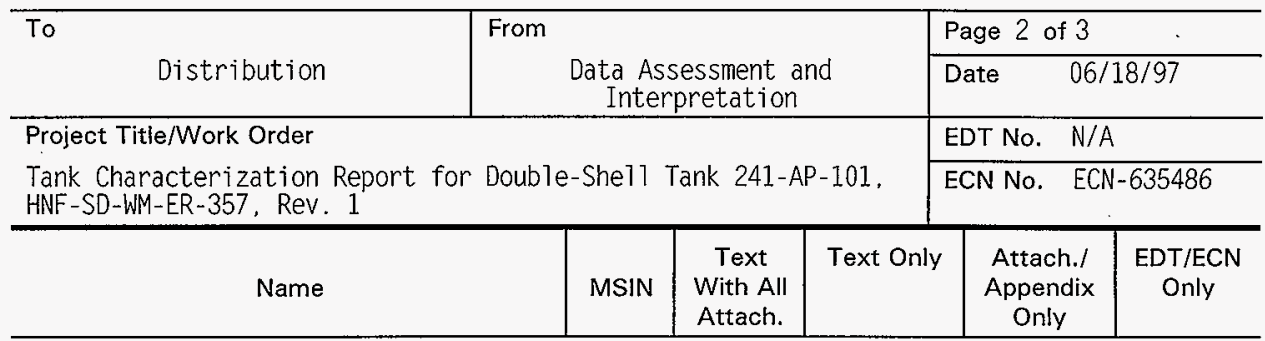

Los Alamos Technical Associates

T. T. Tran

B1-44 $\quad x$

Tank Advisory Panel

102 Windham Road

Oak Ridge, TN 37830

D. 0. Campbe11

ONSITE

Department of Energy - Richland Operations

J. F. Thompson

W. S. Liou

$57-54$

S7 -54

S7-54

J. A. Poppiti

N. W. Willis

S7-54

$x$
$x$
$x$
$x$

DE\&S Hanford, Inc.
R. J. Cash
W. L. Cowley
G. L. Dunford
G. D. Johnson
J. E. Meacham

$x$

Fluor Daniel Northwest

J. L. Stroup

Lockheed Mart in Hanford, Corp.

J. M. Conner

K. M. Hodgson

T. J. Kelley

L. M. Sasaki

B. C. Simpson

L. R. Webb

ERC (Environmental Resource Center)

Tank Characterization Resource Center

Lockheed Martin Services. Inc.

B. G. Lauzon

Central Files

EDMC
S7-14

R2-54

A2-34

S7-14

S7-14

S3-09 $x$

R2-12

$\mathrm{H} 0-34$

S7-21

R2-12

R2-12

R2-12

R1-51

R2-12

$x$
$x$
$x$
$x$
$x$

R1-08

A3- 88

H6-08

$x$
$x$
$x$
$x$
$x$
$x$
$x$
5

$x$
$x$
$x$ 
DISTRIBUTION SHEET

\begin{tabular}{|c|c|c|c|c|c|}
\hline \multirow[b]{2}{*}{ Distribution } & \multirow{2}{*}{\multicolumn{3}{|c|}{$\begin{array}{l}\text { Data Ass } \\
\text { Interp }\end{array}$}} & \multicolumn{2}{|l|}{ Page 3 of 3} \\
\hline & & & & \multicolumn{2}{|c|}{ Date $\quad 06 / 18 / 97$} \\
\hline \multicolumn{4}{|l|}{ Project Title/Work Order } & \multicolumn{2}{|l|}{ EDT No. N/A } \\
\hline \multicolumn{4}{|c|}{$\begin{array}{l}\text { Tank Characterization Report for Double-She11 Tank 241-AP-101, } \\
\text { HNF-SD-WM-ER-357, Rev. } 1\end{array}$} & \multicolumn{2}{|c|}{ ECN No. $. E C N-635486$} \\
\hline Name & MSIN & $\begin{array}{l}\text { Text } \\
\text { With All } \\
\text { Attach. }\end{array}$ & Text Only & $\begin{array}{l}\text { Attach./ } \\
\text { Appendix } \\
\text { Only }\end{array}$ & $\begin{array}{l}\text { EDT/ECN } \\
\text { Only }\end{array}$ \\
\hline
\end{tabular}

Numatec Hanford Corporation

J. S. Garfield

J. S. Hertze

H5- 49

H5-61

D. L. Lamberd

H5-61

$X$
$X$
$X$

Pacific Northwest Nationa 7 Laboratory

A. F. Noonan

K9-91 $\quad x$

Rust Federal Services of Hanford, Inc.

C. T. Narquis

T6-16 X

SGN Eurisys Services Corp.

D. B. Engelman

L6-37 X

